\title{
PROGRAM SOLICITATION
}

Closing Date: March 1, 1995

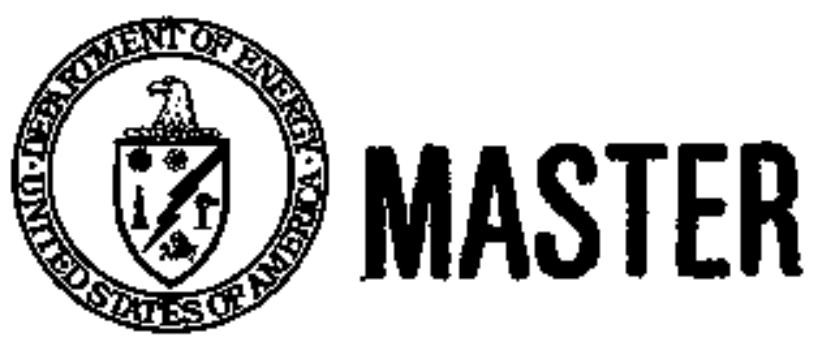

U.S. Department of Energy Office of Energy Research SBIR Program Manager

Washington, D.C. 20585

DASTRIEUTION OF THIS DOCUMENT IS UNIIMITED 


\section{DISCLAIMER}

This report was prepared as an account of work sponsored by an agency of the United States Government. Neither the United States Government nor any agency thereof, nor any of their employees, make any warranty, express or implied, or assumes any legal llablitity or responsibility for the accuracy, completeness, or usefulness of any information, apparatus, product, or process disclosed, or represents that its use would not infringe privately owned rights. Reference herein to any speciffc commercial product, process, or service by trade name, trademerk, manufacturer, or otherwise does not necessarily constitute or imply its endorsement, recommendation, or favoring by the United States Government or any agency thereof. The vlews and opinions of authors expressed herein do not necessarily state or reflect those of the United States Government or any agency thereof. 


\section{DISCLAIMER}

Portions of this document may be illegible in electronic image products. Images are produced from the best available original document. 


\section{TABLE OF CONTENTS}

1. PROGRAM DESGRIPTION $\ldots \ldots \ldots \ldots \ldots \ldots \ldots \ldots \ldots \ldots \ldots \ldots \ldots \ldots \ldots \ldots \ldots$

1,1 Introduction $\ldots \ldots \ldots \ldots \ldots \ldots \ldots \ldots \ldots \ldots \ldots \ldots \ldots \ldots \ldots \ldots \ldots \ldots \ldots \ldots \ldots \ldots \ldots \ldots$

1,2 Three-Phase Progrgm $\ldots \ldots \ldots \ldots \ldots \ldots \ldots \ldots \ldots \ldots \ldots \ldots \ldots \ldots \ldots \ldots+\ldots \ldots \ldots \ldots \ldots 1$

1,8 Followan Funding $\ldots \ldots \ldots \ldots \ldots \ldots+\ldots+\ldots \ldots \ldots \ldots \ldots \ldots \ldots \ldots \ldots \ldots \ldots \ldots \ldots \ldots 1$

1,4 Eligibility and Limitations $\ldots \ldots \ldots \ldots \ldots \ldots \ldots \ldots \ldots \ldots \ldots \ldots \ldots \ldots \ldots \ldots \ldots \ldots \ldots \ldots 2$

1,5 Principal Investigator $\ldots \ldots \ldots \ldots \ldots \ldots \ldots \ldots \ldots \ldots \ldots \ldots \ldots \ldots \ldots \ldots \ldots \ldots \ldots \ldots \ldots \ldots \ldots 2$

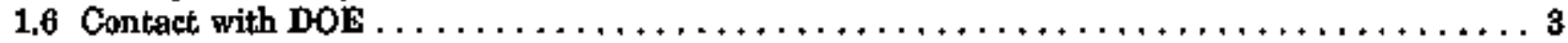

1.7 Support from National Laboratories and Universities $\ldots \ldots \ldots \ldots \ldots \ldots \ldots \ldots \ldots+\ldots \ldots \ldots 3$

2. DEFINTIONS $\ldots \ldots \ldots \ldots \ldots \ldots \ldots \ldots \ldots \ldots \ldots \ldots \ldots \ldots \ldots \ldots \ldots \ldots \ldots \ldots \ldots \ldots \ldots \ldots \ldots 4$

2.1 Research or Research and Development $\ldots \ldots \ldots \ldots \ldots \ldots \ldots \ldots \ldots \ldots \ldots \ldots \ldots \ldots \ldots \ldots 4$

2.2 Innovation $\ldots \ldots \ldots \ldots \ldots \ldots \ldots \ldots \ldots \ldots \ldots \ldots \ldots \ldots \ldots \ldots \ldots \ldots \ldots \ldots \ldots \ldots \ldots \ldots \ldots$

2.8 Small Business Concern $\ldots \ldots \ldots \ldots \ldots \ldots \ldots \ldots \ldots \ldots \ldots \ldots \ldots \ldots \ldots \ldots \ldots \ldots \ldots \ldots \ldots \ldots 4$

2.4 Socially and Eecnomically Disadvantaged Bmal] Business Concern $\ldots \ldots \ldots \ldots \ldots \ldots \ldots \ldots \ldots+4$

2.5 Women-Owned Small Business Concern $\ldots \ldots \ldots \ldots \ldots \ldots \ldots \ldots \ldots \ldots \ldots \ldots \ldots \ldots \ldots \ldots$

2.6 Subcontract $\ldots \ldots \ldots \ldots \ldots \ldots \ldots \ldots \ldots \ldots \ldots \ldots \ldots \ldots \ldots \ldots \ldots \ldots \ldots \ldots \ldots \ldots \ldots \ldots$

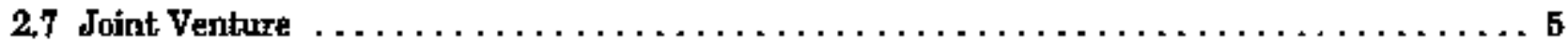

3. APPLICATION PREPARATION INSTRUCTIONS AND REQUIREMENTS $\ldots \ldots \ldots \ldots \ldots \ldots$.

3.1 Grant Applization Requirements $\ldots \ldots \ldots \ldots \ldots \ldots \ldots \ldots \ldots \ldots \ldots \ldots \ldots \ldots \ldots$

3.2 Protection of Grant Application Information $\ldots \ldots \ldots \ldots \ldots \ldots \ldots \ldots \ldots \ldots \ldots \ldots \ldots \ldots \ldots \ldots, 6$

3.3 General Content $\ldots \ldots+\ldots \ldots \ldots \ldots \ldots \ldots \ldots \ldots \ldots \ldots+\ldots+\ldots \ldots+\ldots \ldots+\ldots \ldots \ldots \ldots 6$

3.4 Phese I Grant Application Format $\ldots \ldots \ldots \ldots \ldots \ldots \ldots \ldots \ldots \ldots \ldots \ldots \ldots \ldots \ldots \ldots$

4. METHOD OF SELECTION AND EVALUATION CRITERIA $\ldots \ldots \ldots \ldots \ldots \ldots \ldots \ldots \ldots \ldots 10$

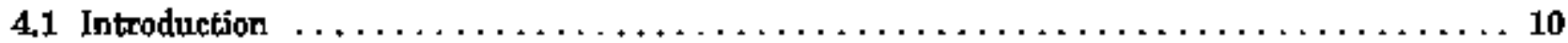

4.2 Evaluation Criteria-Phase I $\ldots \ldots \ldots \ldots \ldots \ldots \ldots \ldots \ldots \ldots \ldots \ldots \ldots \ldots \ldots \ldots \ldots 10$

4.3 Evaluation Criteria-Phase II $\ldots \ldots \ldots \ldots \ldots \ldots \ldots \ldots \ldots \ldots \ldots \ldots \ldots \ldots \ldots \ldots \ldots \ldots \ldots$

6. Considerations $\ldots \ldots \ldots \ldots \ldots \ldots \ldots \ldots \ldots \ldots \ldots \ldots \ldots \ldots \ldots \ldots \ldots \ldots \ldots \ldots \ldots \ldots 11$

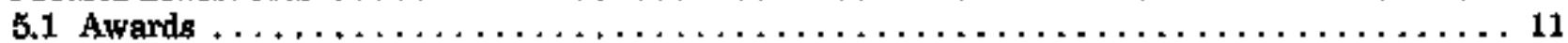

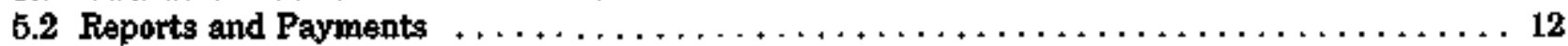

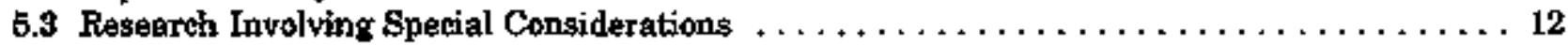

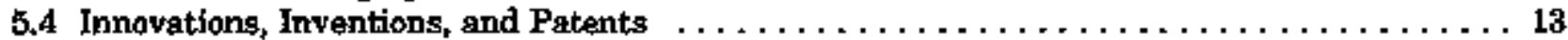

5.5 Cost Sharing, Joint Ventures, and In-House Work $\ldots \ldots \ldots \ldots \ldots \ldots \ldots \ldots \ldots \ldots \ldots+13$

5.6 Nondiscrimination in Federally Assisted Programs $\ldots \ldots \ldots \ldots \ldots \ldots \ldots \ldots \ldots \ldots \ldots \ldots \ldots \ldots+\ldots$

5.7 Grantee Contmitments $\ldots \ldots \ldots \ldots \ldots \ldots \ldots \ldots \ldots \ldots \ldots \ldots \ldots \ldots \ldots \ldots \ldots \ldots \ldots+14$

6.8 Additional Information $\ldots \ldots \ldots \ldots \ldots \ldots \ldots \ldots \ldots \ldots \ldots \ldots \ldots \ldots \ldots \ldots \ldots \ldots \ldots \ldots \ldots 14$

6. SUBMISSION OF GRANT APPLICATIONS $\ldots \ldots \ldots \ldots \ldots \ldots \ldots \ldots \ldots \ldots \ldots \ldots \ldots \ldots$ is

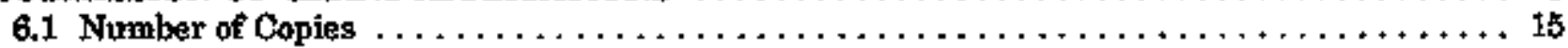

6.2 Deadline for Receipt of Grant Applications $\ldots \ldots \ldots \ldots \ldots \ldots \ldots \ldots \ldots \ldots \ldots \ldots \ldots \ldots \ldots$ IS

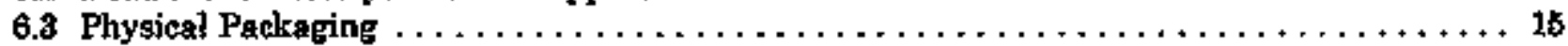

7. SCIENTIFTC AND TECHNICAL INFORMATION SOURCES $\ldots \ldots \ldots \ldots \ldots \ldots \ldots \ldots \ldots \ldots$

7.1 National Technical Information Service $\ldots \ldots \ldots \ldots \ldots \ldots \ldots \ldots \ldots \ldots \ldots \ldots \ldots \ldots$

7.2 DOE Office of Scientific and Technical Information $\ldots \ldots \ldots+\ldots \ldots \ldots \ldots \ldots \ldots+\ldots \ldots$ 


\section{APPENDIXES}

A Grant Application Cover Page $\ldots \ldots \ldots \ldots \ldots \ldots \ldots \ldots \ldots \ldots \ldots \ldots \ldots \ldots \ldots \ldots \ldots 17$

B. Project Summary $\ldots \ldots \ldots \ldots \ldots \ldots \ldots \ldots \ldots \ldots \ldots \ldots \ldots \ldots \ldots \ldots \ldots \ldots \ldots \ldots \ldots \ldots \ldots+19$

C. Sample Project Description $\ldots \ldots \ldots \ldots \ldots \ldots \ldots \ldots \ldots \ldots \ldots \ldots \ldots \ldots \ldots \ldots \ldots \ldots \ldots \ldots \ldots 21$

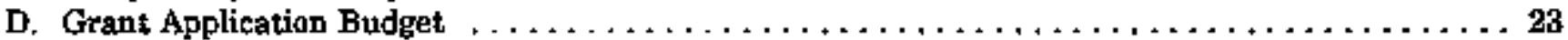

E. Certifications Regarding Lobbying, Debarment, Suspension, and Other

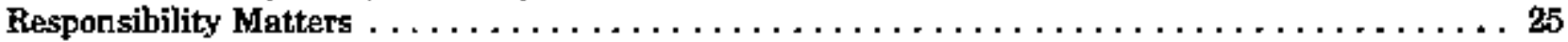

F. Certification Regarding Drug-Free Workplace Requirements $\ldots \ldots \ldots \ldots \ldots \ldots \ldots \ldots \ldots \ldots \ldots 26$

G. Checklist/Statistical Information Forms $\ldots \ldots \ldots \ldots \ldots \ldots \ldots \ldots \ldots \ldots \ldots \ldots \ldots \ldots \ldots \ldots 27$

H. Index for Sections $1-7$ and Appendices A G $\ldots \ldots \ldots \ldots \ldots \ldots \ldots \ldots \ldots \ldots \ldots \ldots \ldots \ldots$

1. Technical Topic Description $\ldots \ldots \ldots \ldots \ldots \ldots \ldots \ldots \ldots \ldots \ldots \ldots \ldots \ldots \ldots \ldots \ldots \ldots \ldots \ldots, \mathbf{9 1}$

1. Novel Materials for Sustainable Energy Development $\ldots \ldots \ldots \ldots \ldots \ldots \ldots \ldots \ldots \ldots$ 31

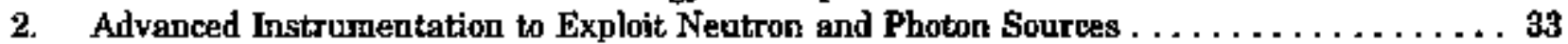

3. Ceramic Fibers and Fiber Coatings for High Temperature Applications . . . . . . 34

4. Chemical Seiences Research $\ldots \ldots \ldots \ldots \ldots \ldots \ldots \ldots \ldots \ldots \ldots \ldots \ldots \ldots \ldots \ldots \ldots \ldots \ldots \ldots, 85$

5. Information Infrastructure for the National Information Initiative $\ldots \ldots \ldots \ldots \ldots \ldots \ldots$. $\ldots 7$

6. High Temperature Superconductivity for Enercy Applications $\ldots \ldots \ldots \ldots \ldots \ldots \ldots, 38$

7. Improved Materials for the Pulp and Paper Industry $\ldots \ldots \ldots \ldots \ldots \ldots \ldots \ldots \ldots$

8. Advanced Drilling Technology $\ldots \ldots \ldots \ldots \ldots \ldots \ldots \ldots \ldots \ldots \ldots \ldots \ldots \ldots \ldots \ldots$ 4I

9. Advanced Environmental Monitoring Technology $\ldots \ldots \ldots \ldots \ldots \ldots \ldots \ldots \ldots \ldots$ 42

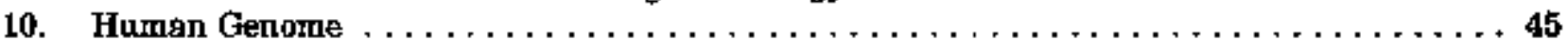

11. Computerized Processing of Biological Date $\ldots \ldots \ldots \ldots \ldots \ldots \ldots \ldots \ldots \ldots \ldots \ldots \ldots+46$

12. Atmospheric Measurement and Sampling Technologies $\ldots \ldots \ldots \ldots \ldots \ldots \ldots \ldots \ldots \ldots$ 48

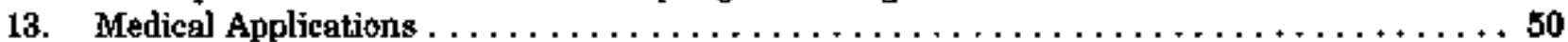

14. High Energy Physies Educetional and Teaching Ajds $\ldots \ldots \ldots \ldots \ldots \ldots \ldots \ldots \ldots \ldots$ 51

15. Technology and Instrumentation for Figh Enersy Accelerators $\ldots \ldots \ldots \ldots \ldots \ldots \ldots \ldots \ldots$, 52

16. High Energy Physics Data Processing and Detector Instrumentation $\ldots \ldots \ldots \ldots \ldots \ldots, 54$

17. Nuclear Physics Instrumentation and Techniques $\ldots \ldots \ldots \ldots \ldots \ldots \ldots \ldots \ldots \ldots \ldots$

18. Nuclear Physics Accelerator Technology $\ldots \ldots \ldots \ldots \ldots \ldots \ldots \ldots \ldots \ldots \ldots \ldots$

19. Plasma Confinement Systems Technology $\ldots \ldots \ldots \ldots \ldots \ldots \ldots \ldots \ldots \ldots \ldots \ldots \ldots$

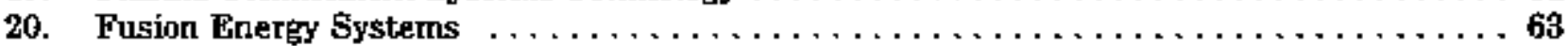

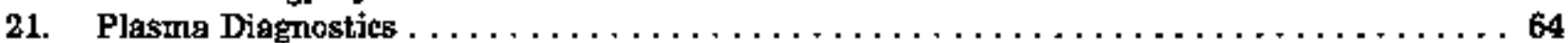

22. Technology and Instrumentation for Heavy Ion Fusion Acelerators $\ldots \ldots \ldots \ldots \ldots \ldots$

23. Cost-Effective Methods for Coating Polymers $\ldots \ldots \ldots \ldots \ldots \ldots \ldots \ldots \ldots+\ldots \ldots \ldots \ldots \ldots 67$

24. Research on the Electronic Exchange of Scientific and Technical

Information Among Organizations $\ldots \ldots \ldots \ldots \ldots \ldots \ldots \ldots \ldots \ldots \ldots \ldots \ldots \ldots \ldots$

25. Elemental Tritiom Collection Technology $\ldots \ldots \ldots \ldots \ldots \ldots \ldots \ldots \ldots \ldots \ldots \ldots \ldots \ldots \ldots 69$

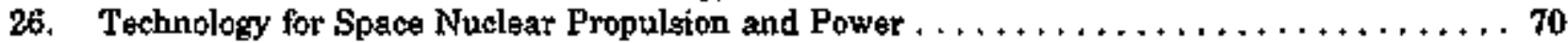

27. Magurement and Characterization of Materials in Civilian Nuclear Reactors $\ldots \ldots \ldots \ldots 72$

28. Characterization, Monitoring, and Sensor Tethnologies for Radioactive

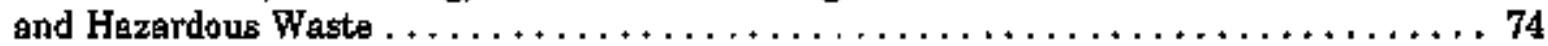

29. In-Situ Treatment of Metal Contaminated Soils and Groundwater $\ldots \ldots \ldots \ldots \ldots \ldots \ldots$

30. Chemical Separation Processes for Waste Treatment $\ldots \ldots \ldots \ldots \ldots \ldots \ldots \ldots \ldots \ldots 78$

81. Computer Storage and Analysis for Nonproliferation Data Collection $\ldots \ldots \ldots \ldots \ldots \ldots 80$

32. Laser Technology for Chemical Analysis for Nonproliferation Activities . . . . . . . . . 81

33. Improved Sensor Technology for Nationa] Security and Nonproliferation of Weapons . . . . 82

34. Environmental Teehnology for Natura] Gas, Oil, and Coal $\ldots \ldots \ldots \ldots \ldots \ldots \ldots \ldots \ldots$

35. Advanced Recovery of $\mathrm{Oil} \ldots \ldots \ldots \ldots \ldots \ldots$ 
36. Natural Gas Supply $\ldots \ldots \ldots \ldots \ldots \ldots \ldots \ldots \ldots \ldots \ldots \ldots \ldots \ldots \ldots \ldots \ldots+\ldots \ldots \ldots$ 87

37. Natural Gas Utilization $\ldots \ldots \ldots \ldots \ldots \ldots \ldots \ldots \ldots \ldots \ldots \ldots \ldots \ldots \ldots \ldots \ldots \ldots$

38. Advanced Coal-Based Power Systems $\ldots \ldots \ldots \ldots \ldots \ldots \ldots \ldots \ldots \ldots \ldots \ldots \ldots \ldots \ldots \ldots \ldots \ldots, 89$

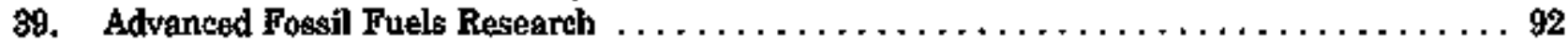

40. Improved Technology for Obtaining Recyclable Materjal from Municipal Solid Waste . . . . 99

41. Ljghtweight Composite Material for Automotive Structures $\ldots \ldots \ldots \ldots \ldots \ldots \ldots \ldots \ldots 94$

42. Hybrid Electric Vehicle Teahnology $\ldots \ldots \ldots \ldots \ldots \ldots \ldots \ldots \ldots \ldots \ldots \ldots \ldots \ldots \ldots \ldots$ 98

43. Modular and Panelized Passive Soler Buildings $\ldots \ldots \ldots \ldots \ldots \ldots \ldots \ldots \ldots \ldots \ldots \ldots$ 96

44. Technical Improvements for Advancing Photovoltaic Applications $\ldots \ldots \ldots \ldots \ldots \ldots \ldots$ 


\section{DOE PROGRAM SOLICITATION FOR SHALL BUSINESS INNOVATION RESEARCH}

\section{PROGRAM DESCRIPTION}

\subsection{INTRODUCTION}

The Department of Energy (DOE) invites small business concerns to submit grant applications under this thirteenth annual solicitation for the Small Business Innovation Research (SBIR) program. Firms with strong research capabilities in science or engineering in any of the topic areas described in Appendix I are encouraged to participate. DOE will support high-ouality research or research and development (R\&D) on advenced concepts concerning important energy related seientitic or engineering problems and opportunities that could lead to significant public benefit if the research is sexccessfive?

Objectives of this progrem inclode increasing private sector commercialization of technology developed through DOE-supported $\mathrm{H} \& \mathrm{D}$, stimulating technologieal innovation in the private sector, strengthening the role of amall business in mesting Federal research and R\&D needs, and improving the return on investrnent from Federally funded research for economic and social benefits to the Nation.

\subsection{THREE-PHASE PROGRAM}

This program solicitation is issued pursuant to the Small Business Research and Development Enhance. ment Act of 1992, Public Law 102-564. Under Phage I, DOE anticipates making approximately 200 grant awards from this solicitation during ffseal year 1995 to small buisinesses in amounts up to $\$ 75,000$ for a project period of abont 6 months. Fhase $I$ is to evaluate, insofar as possible, the scientific or technicgl merit and feasibility of ideas that appear to have commercial potential, submitted under the SBIR program. The grant appilcation should concentrate on research that will contribute to proving scientific or technical feasibility of the approach or concept and would be a prerequisite to further DOE support in Phase U. The successful completion of Phase I objectives will be a prerequisite to a Phase II grant application, and the proposed Phese II studies must be in the same tochnical topic and subtopic as the Phase I studies.
Only those Phase I grantees selected through this solicitation will be eligible to compete for the subsequent Phase II continuation of their Phase I projects.

Phase II awards are expected to be made during fistal year 1996 to firms with approaches that appear sufficiently promising as a result of the Phaze I effort. Phase II grant awards are expeeted to be in amounts up to $\$ 750,000$ and to cover a period of up to 24 months. It is anticipated that one-third to one-half of Phase 1 awardees will receivs Phase II awards, depending on Phase I results and availability of funds. Phase II is the principal R\&D effort. Instructions for the preparation of the Phase II grant application wiI] be provided to all Phase I grantees at the time of the Phase I award.

Under Phase III, it is intended that non-Federal capital be used by the small business concern to pursue commercial applications of the R\&D. Also, under Phase III, Federal agencies may award non-SBIR funded follow-on grants or contracts for (1) products or processes that meet the mission needs of those agencies, or (2) further research or F\&D. This follow* on work results from SBIR projects that were competitively selected in Phases I and II by seientifiel technicgl review criteria. The work proposed for Phases I and II, assuming that it proceeds sucoessfully, should be suitable in nature for subseguent progression to Phase III.

This solicitation is for Phese I grant applications only, but it degcribes some aspects of Phase II grants as reference information. Further information will be provided to Phase I grantees on how to apply for Phase II.

\subsection{FOLLW-ON FUNDING}

An important goal of this program is the commercialization of DOE-supported research or RED. The DOE program includes en incentive for applicants to obtain a contingent commitment prior to $\mathbf{P h a s e}$ II to continue 
the innovation process where the research or R\&D also has commercial potential. (See Phase II Evaluation Criterion $6 c$ in Section 4.3) SBIR funding pays for research or R\&D meeting DOE objectrives (Phsses I and II); private capital provides follow-on developmental funding to meet commercial objectives (Phase III).

Following the start of Phase $I$, applicants whose research or R\&D has identifiable potential to meet market needs should seek commitments from private sector or non-SBIR funding sources for both Phases II and III. (See Evaluation Criterion 6 in Section 4.3.) The commitments should be obtained prior to the Phase II grant application submission. The commitment for Phase ill may be made contingent on the DOE-supported research or R\&D meeting some specific technical objectives in Phase II, which, if met, would justify tunding to pursue further development for commercial purposes in Phase UI.

\subsection{ELIGIBILITY AND LIMITATIONS}

In addition to the instructions given in Section 3 , the following eligibility conditions and limitations apply:

Multiple Applications - Each grant application must be submitted to only one topic and, within it, to only one subtopic described in Appendix I. Duplicate grant applications will be rejected without review. However, there is no limitation on the number of different grant applications that a small business may submit under this solicitation, even to the same subtopic.

Similar Applications-Grant applications that are similar to each other may be submitted, but no more than one such grant application will be funded as a result of this solicitation.

Responsiveness-To be considered responsive, a grant application must fall within the description of the subtopic, and also satisfy any conditions contained in the introductory section of that topic. The language in both the topic introductions and the subtopies should be taken literally. Applieations that do not directly address the subtopic statement will be declined for non-responsiveness.

Choice of Topic and Subtopic-DOE will not assign a topic and/or subtopic to grant applications; this must be done by the applieant. When a grent application has relevance to more than one subtopic, the applicant must decide which subtopic is the most relevant and submit the grant application under that subtopic only.

Grant Applications Being Congidered for Other Funding-If a grant application that is substantially the same as the one submitted in response to this solicitation has been previously funded, or is pending at, or about to be submitted to another Federal agency, or to other DOE programs as a separate action, the applicant must so indicate and provide the information required by Section 3.4.2.j. If an award is made pursuant to a grant application sabmitted under this SBIR solicitation, the Brantee will be required to certify that neither the grantee oreanization nor any of its employees have previously been, nor are currently being paid for essentially equivalent work by an agency of the Federal Government.

Qualifying as a U.S. Small Business ConcernEach concerm submitting a grant application must qualify as a small business for research or R\&D purposes as defined in Section 2.3. Also, for both Phase I and Phase II, the research or R\&D work must be performed in the United States. "United States" means the 50 states, the territories and possessions of the United States, the Commonwealth of Puerto Rice, the Trust Territory of the Pacific Islands, and the District of Columbia.

\subsection{PRINCIPAL INVESTIGATOR}

The Principal Investigator (PI) should be knowledge able in all technical aspects of the grant application and bo capable of leading the research effort.

The PI's primary employment must be with the small business at the time of award and during the conduct of the proposed research. Primary employment means that more than one-half of the PI's time, but no less than 20 hours (avergge) per week, is spent in the employment of the small business during the conduct of the project. Primary employment with 6. small business precludes fill-time employment with another organization. In addition, the PI is expected to devote to the project a considerable part of his or her time, and in no case less than 5 hours (average) per week for the duration of the project. Before the grant is awarded, the PI will be required to sign a statement certifying adherence to all of the above requirements. 
In order to ensurg appropriate technical guidance for the project, only one PI will be accepted per project; co-PIs will not be accepted.

Grant applicetions will be evaluated against $a i l$ of the criteria listed in Section 4.2. Since the qualifications of the PI play an important role in Criterion 3, the following rules shall apply to any substitution in PI after the closing date of the solicitation: (1) After the closing date but prior to the award selection, no substitution in PI will be considered. (2) For grant applications selected for funding, but prior to grant award, any proposed substitution in PI will be viewed as a substantial change in the original grant application, and no award will be issued unless DOE expressly approves the substitution. (3) During the tarm of the grant, any change in the PI will require prior written approval by DOE.

\subsection{CONTACT WITH DOE}

Questions about the DOE SBIR program may be addreased to Mrs. Kay Etzler, Prosram Spokesperson, to SBIR Program Manager, ER-16, U.S. Department of Einergy, Washington, D.C. 20585, telephone (301) 908-5867. Requests for eopies of the solicitation may be addressed to the SBIR Program Office at the above address [telephone (301) 903-5707], For reasons of competitive fairness, communications with any Federal Government personnel regarding this solicitation are limited to non-technical matters during the grant application preparation period. Interpretations of the technical topics in Appendix I will not be given. However, the staff of DOE national lahoratories or ather contractor-operated laboratories may provide assistence, or may even enter jnto an agreement to participate in a grant application, as described in Section 1,7 below.

The selection of grant applications for awards will be completed approximately four months after the closing date of the solicitation. Grant awards will be completed appraximately two months thereafter. No information on grant application status will be available until the final selections have been made. However, if a grant application acknowledgement with an assigned grant application number is not recoived from $D O E$ within three weeks of the closing date, the applicant should telephone (301) 908-5867.

\subsection{SUPPORT FROM NATIONAL LABORATORIES AND UNIVERSITIES}

In the last few years, more than half of the successfit applicants to the DOE SBIR program have arranged for support from a DOE national laboratory or a university in their SBIR project.

The DOE national laboratories' technical expertise and equjpment may be available to you urder existing DOE approved mechanisms for providing services and materials to non-Federal entities. Your compary must have the necessary expertise to direct the entire project, because a laboratory will not perform tasks beyond your technical understanding. If you are not cognizant of the appropriate person or departonent at, a laboratory, you may telephone the FLC Locator of the Federal Laboratory Consortium for Technology Tranefer on 206-683-1005 to obtain the name of an appropriate contact, or write to Dr. Andrew Cowan, Manager, FLC Locater, P.O. Box 545, Sequim, WA 98382.

A minimum of two-thirds of the funded resegrch or analytical effort during Phase I (or one-half during Phase II) must be performed by the applicant organization (see Section 5.5). Work done by a national laboratory will be considered as external to the applicant organization.

Similar support may be obtained from a university. Inquiries can be made at one nearby, or at a local library, to locats the supporting expertise or facilities needed for your project. 


\section{DEFINITIONS}

The following definitions apply for purposes of this solicitation:

\subsection{RESEARCH OR RESEARCH AND DEVELOPMENT}

Research or R\&D is any scientific or engineering activity which is (1) a systematic, intensive study directed toward greater knowledge or understanding of the subject; (2) \& systematic study directed specifically toward applyting new knowledge to meet a recognized need; and/or (3) a systematic application of knowledge tow ard the production of usefu] materials, devices, and systems or methods, including design, development, and improvement of prototypes and new processes to meet specific requirements.

\subsection{INNOVATION}

Innovation is the process of introducing new ideas into use, or the process of introducing novel uses of existing ideas.

\subsection{SMALL. BUSINESS CONCERN}

A suall business concern is one that at the time of award of Phase I (and of Phase II, if awarded):

a. is independently owned and operated, is not dominant in the field of operation in which it is proposing, has its principal place of business located in the United States (as defined in Section 1.4), and is orgenized for profit;

b. is at least 51 percent owned, or in the case of a publicly opned business has at lesst 51 percent of its voting stock owned, by United States citizens or lawfully admitted permanent resident akiens; and

c. has, including its affiliates, a number of employees not exceeding 500 and meets the other regulatory requirements found in 13 CFR Part 121. Business concerns, other than licensed investment companies or state development companies qualifying under the Small Business Investment Act of 1958, 15 U.S.C. 661 at seq., are affiliates of one another when either, directly or indirectly, (1) one concern controls or has the power to control the other, or (2) third parties (or party) control or have the power to control both. Control tan be exercised through common ownership, confrion management, and contractoal relationship. The term "gffiltiates" is defined in greater detail in $\mathbf{1 3}$ CFR 121.3-2(a). The term "number of employees" is defined in $13 \mathrm{CFR} 121 . \mathrm{a} 2(\mathrm{t})$. Business concerns include, but are not limited to, any indjvidual, partnership, corporation, joint venture, association, or cooperative.

\subsection{SOCIALLY AND ECONOMICALLY DISADVANTAGED SMALL BUSINESS CONCERN}

A socially and economically disadvantaged small business concern is one:

a. that is at least 51 percent owned by (i) an Indian tribe or a native Hawaiian organization, or (ij) one or more socially end economically disadvantaged individuals; and;

b. whose management and daily businesg operations are controlled by one or more socially and economically disadvantaged individuals. A socially and economically disadvantaged individual is defined as a member of any of the following groups: Black Americans, Hispanic Americans, Native Americans, Asian-Pacific Americans, Subcontinent Asian Amer* icans, other groups designated from time to time by the Small Business Administration (SBA) to be socially disadvantaged, or any other individual found to be socially and economically disadvantaged by SBA pursuant to section \&(a) of the Small Business Act, 15 U.S.C. $6 \$ 7(a)$.

\section{WOMEN-OWNED SMALL BUSINESS CONCERN}

A women-owned small business concern is a small business that is at least 51 percent owned by a woman or women who also control and operate it. "Control" in this context means exercising the power to make policy decisions. "Operate" in this context means being actively involved in the day-to-day management. 


\subsection{SUBCONTRACT}

A subcontract is any agreement, other than one involving an employer-employes relationship, entered into by the primary recipient, of a Federal Government grant, calling for supplies or services required solely for the performance of the original grant award.

\subsection{JOINT VENTURE}

A joint venture is an association bstween two or more firms to participate jointly in a single business enterprise. There must be a community of interests, a sharing of profits and losses, and, for the purposes of this solicitation, the new entity must qualify as a smal] business concern as defined in Section 2.8 .

\section{APPLICATION PREPARATION INSTRUCTIONS AND REQUIREMENTS}

\subsection{GRANT APPLICATION REQUIREMENTS}

The purpose of a grant application to DOE under the SBIR program is to provide sufficient information to convince DOF, and members of the research community who review the grant appliantion, that it. is responsive to the subtopic under which it is submitted, that the proposed work represents a sound approach to the investigation of an importiant scientitic or engineering question, and that it is worthy of support under the stated criterie. Experts at institutions such as colleges, universities, and DOE contractor operated national laboratories may be consulted during the preparation of the grant epplicetion. The grant application should concentrate on research that will contribute to proving scientific or technical feasibility of the approach or concept and would be a prerequisite to further DOE support in Phase II. Where the scientific or technical merit of the innovation or its essential feasibility has already been established, the work will not be considered for SBIR funding.

The quality of the scientific or technical content of the erant application will be the principal basis on which applications will be evaluated. The work propesed tor Phese I, assuming that it proceeds successfully, should be suitable in nature for subsequent progression to Phases II and III. A grant application should be self-contained and written with the care and thoroughness accorded papers for publication. Each Phase I grant, application should be reviewed carefully by the applicant - to ensure inclusion of data essential for evaluation using the checklist provided in Appendix $G$.

Appendix $!$ lists 44 technical topics, in an arbitrary order, numbered 1 through 44, Each technical topic is subdivided into no more than 4 subtopies; each is designated by a letter a, b, c, or d. A grant application must respond to only one technical topic and, within it, to only one Bubtopic. (See the limitations given in Section 1.4.). Both the topic number and the subtopic letter must be entered in the appropriate spaces on the cover page (Appendix A). Failure to identify both the topic and subtopic, or failure to respond, in the subject matter of the grant application, to the subtopic (within a topic) identifed on the cover page by the applicant, will cause the grant application to be declined without further review.

The proposed research must be responsive to the DOE program objectives, and should also serve as the base for technological innovation and new commercial products, processes, or services. Grant applications must be confined to advanced concepts in energyrelated scientific or engineering research which may be carried out through fabrication and evaluation of a laboratory prototype where necessary. Phase I research can include innovative design of hardware or software, and the evaluation or optimization of such design, where this is specifically invited under the subtopic description. Specifically excluded from this solicitation are exant applications principally for literature surveys, for compilations of the work of others, for technical assessments, or for technical status surveys. Grant applications primerily for the development of already proven concepts should not be submitted, because such efforts are considered the responsibility of the private sector. Commercialization is the ohjective of Phase III, where the research or R\&DD supported by DOE under Phases I and II can be continued using non-SBIR funding.

All consultants, instrumentation, and physicgl facilities identified in the crant application must be available for the research or R\&D project. The consultants who are identified in the grant application must have 
agreed to serve in the manner and to the extent described in the application, and the application must contain a specific statement to that effect (see Section 3.4.2.i.). If the instrumentation, equipment, and physical facilities to be used are not the property of the applicant, and are not to be purchased or leased for this project, their source must be identified and their availability specifically confirmed in the grant application (see Bection 3.4.2.h.) Statements certifying to consultant avajlability and salary, and national laboratory (or other source) faeilities or instrumentation and rental terms, must be signed by a principal and submitted with the grant application. If the grant application is selected for an award, the grant may not be awarded unless all of the above are available.

\subsection{PROTECTION OF GRANT APPLICATION INFORMATION}

DOE's policy is to use data included in grant, applications for evaluation purposes only and to protect such information from unauthorized use or disclosure. Protection of trade secrets or other information that is commercial or financial and confidential or privileged is discussed in Section \$.4.a.

In addition to government personnel, scientists and engineers from outside the Governtent may be used in the grant appliteation evaluation process. The decision to obtgin outside evaluation will take into consideration requirements for the avoidance of organizational conflicts of interest and the competitive relationship, if any, between the applicant and the prospective outside evaluator. The evaluation will be performed under an agroement with the evaluator that the data contained in the grant application will be used only for evaluntion purposes and will not be further disclosed.

\subsection{GENERAL CONTENT}

This solicitation is designed to reduce the investment of time and cost to small firms in preparing a formal grant application. Those who wish to respond should submit a research grant application of no more than 25 conaecutively numbered pages stapled together, including cover page, project summary pege, main text, references, resumes, budget, and any other enclosures or attachments. The pages must be of standard $81 / 2 " \times 11^{\prime \prime}$ size $(21.6 \mathrm{~cm} \times 27.9 \mathrm{~cm})$. For proportionally-spaced fonts, the type can be no smaller than 12 point, and for nonproportionally-spaced fonts, the type can be no smaller than 12 characters per inch (elite). Exceptions will be permitted for legends on reduced drawings but not tables. Margins are not to be less than 1 inch $(2.5 \mathrm{~cm})$. Video tapes or computer disks will not be aceepted.

The grant application should be ditect, concise, and jnformative. Promotional and nonproject-related discussion is discouraged. To meet DOE requirements, all items listed in Section 3.4 are to be covered fully and in the order set forth, but the space allocated to each will depend on the research project chosen and the Principal Investiggtor's approach. All information required by Section 3.4 must be included in the 25 pages except for the listing of multiple Phase II awards which may be required by Section 3.4.4. Appendices $\mathrm{E}$ and $F$ are for information only, and should not be submitted with a grant application. By signing the grant application cover page and marking $Y$ in the thisd certification, the applicant agrees to the conditions in Appendices E and F. Grant applications containing more than 25 pages will not be considered for review or award.

\subsection{PHASE I GRANT APPLICATION FORMAT}

\subsubsection{Introductory Pages}

a. Cover Page-Complete the form identified as Appendix A in the solicitation. Detailed instrutctions are provided on the back of the form. This is to be the cover page on each of the required 8 copies of your grant application. No other cover page is permitted. For multiple applications, photocopy the cover page form before using it.

b. Project Summary-Complete the project summary form identified as Appendix B. Detailed instructions are on the back of the form. This form is page 2 of your grant, application. The project summary should include a briaf description of the research that will be performed in Phase $\mathrm{L}$ Three additional photocopies of the completed Appendix $B$ should be included seperately with your complete submission. For multiple applications, photocopy the project summary form before using it. The project summary 
pagte (Appendix B) mugt not contain proprietary information.

\subsubsection{Primary Content}

a. Identiflcation and Significance of the Problem or Opportunity-(Begin on page 3 of your Erant application.) Define the speciftc technica] problem or opportunity addrassed by your application and ita importance.

\section{b. Background, Technical Approach, and Potential Uses}

1. Indicate the overall background and technical approach to the problem or opportunity and the part that the proposed reseerch plays in providing needed resalts.

2. State the anticlpated results of the approach, with epecial emphasis on commercial potential, if the project is successful and is carried over into Phases II and III. This should addregs the technical, economic, or other benefits to the Nation. Identify any specific groups in the commercial sector, the Federal Government, or other individuals that might be expected to use the profected results. Please bear in mind that Phase III must address either the development of commercial applications, the development of products or processes for use by the Federal Government, or non-SBIR Federally-funded research or R\&-D for concepts developed under Phases I and II. Therefore, in Phase II, it is important to show that the approach will bring the product, process, research, or RAD to suitable readiness for Phase III.

8. Discuse the gignificance of the Phase I effort in providing a foundation for the Phase II research or R\&D effort.

c. Phase I Technical Objectives-State the apecific objectives of the Phase I effort, including the questions it will by to answer to detereaine the feasibitity of the proposed approach.

d. Phase I Work Plan-Provide an explicit, detailed description of the Phase I research approach and work to be performed. The plan should indicate not only what is planned but how the work will be carried ont. The Phase I effort should attempt to determine the technical feasibility of the proposed concept, and if successtial should provide a firm besis for the Phase If grant application.

The work plan should be linked with the objectives and the questions that the Phase I effort is designed to answer. The methods planned to achieve each objective or task should be discussed explicitly and in detail. This section should be a substantial portion of the total grant application.

e. Phase I Project Description-The Project Deseription must summerize items $c$. and $d$. above by very briefly stiating the principal project objective(s), jdentifying the tasks to be performed, and listing the performance schedule. It also should identify the finel report as the only deliverable under Phase I. A sample Project Destription is included as Appendix C. In Phase II the project description will cover the principal regearch or R\&D necessery to prepare the product or process for a Phase III effort.

f. Related Research or R\&D-Degcribe gignificant research that is directly related to the grant apphication, inchuding any conducted by the Prinipal Investigator or by the applicant organization. Describe how it relates to the proposed effort and any planned coordination with outside soverces. The applicant must convince reviewers of his or her awareness of key recent work conducted by others in the specific area of the proposed project.

g. Key Personuel and Bibliography of Directly Related Work-Identify the Principal Investigator and other key personnel involved in Phase I, including their directly related education, experience, and bibliographic information. When vitae are extensive, summaries that focus on the most relevant experience or publications are desired, and such brevity may be necessary to meet the grant application size limitation (see Bection 8.9). It is important that the requirements described in Section 1.5 concerning the Principal Investigator be met explicitly.

h. Facilitiea/Equipment-Describe available instrumentation and physical facilities necessary to carry out the Phase I effort. Items of equipment to be purchased or leased (as detailed in Appendix D) must be justified under this Section, If the equipment, instrumentation, and facilities are not the property of 
the applicant and are not to be purchased or leased, the source must be identified and their avallability spectftcally conflrmed in this section. A principal of the organization, such as a nationa] iaboratory or university, that owns or operates the facilities/equipment must certify regarding the availability and cost of facilities/equipment and any associated technician cost; a copy of this certification must be submitted as part of the grant application.

Only American-made equipment and products should be purchased with finantial assistance provided under both Phase I and Phase II awards to the extent possible in keeping with the overall purposes of the program.

i. Consultants and Subcontractors-Involvement of university or other consultants in the planning and research stagess of the project is permitted subject, to Section 5.5 limitations. If such involvement is intended, it should be described in detail and included in Appendix $\mathrm{D}$ (if appropriate). If consultants or subcontractors are to be used and are identified, this section must contain a specific statement that they have agreed to serve in the manner and to the extent described in the grant application. A statement signed by the consultant certifying hisher availability and salary must be submitted as part of the orant application.

j. Stmflar Grant Applications, Proposals, or Awards-If a proposal or grant application, whether SBIR or not, is substantially the same as the one submitted in response to this solicitation and has been previously funded or is either funded, pending, or about to be submitted to another Federal agency or to the DOE in a separate action, the applicant must provide the following information:

1. The name and address of the egency(s) to which a proposal or grant application was submitted, ar will be submitted, or from which an award is expected or has been received.

2. The date of submission or the date of award.

3. The title of the grant application.

4. The name and title of the project maneger or Principal Investigetor for each proposal or grant application submitted or award received.
5. The number and date of the solicitation under which the application or award was received.

6. The title of the specific research topic to which the application or award was submitted.

\subsubsection{Budget}

Complete the SBIR Grant Application Budget form, Appendix D, for the Phase I effort only. (For maltipls applications photocopy the budget form before using it.) Incorporate the copy of the budget form that bears the ortginal signature inte the copy of the grant application that bears the original signatures on the cover page. No other budget form is permitted.

Under Phase I, a minimum of two-thirds of the funded research or analytical effort must be performed by the proposing firm. Under Phase II, a minimum of onehalf of the funded research or analytical effort must be performed by the proposing firm. To satisfy this criterion for Phase I, at least two-thirds of the funding requested int the grant application budget (line L of Appendix D), excluding any purchased or leased equipment, materials, and supphes, must be allocated to the proposing small business. On a separate "Budget Explanation Page", identify costs for purchased and leased equipment, materials, and sapplies for each subcontractor using the following table:

\begin{tabular}{||l|c|c||}
\hline \multicolumn{2}{c|}{ Cost (in dollars) } \\
\hline & $\begin{array}{c}\text { Subcontractor } \\
\# 1\end{array}$ & $\begin{array}{c}\text { Subcontractor } \\
\text { \#2 }\end{array}$ \\
\hline $\begin{array}{l}\text { Purchased } \\
\text { Equipment }\end{array}$ & & \\
\hline $\begin{array}{l}\text { Leased } \\
\text { Equipment }\end{array}$ & & \\
\hline $\begin{array}{l}\text { Materials } \\
\text { and Supplies }\end{array}$ & & \\
\hline Total & & \\
\hline
\end{tabular}

Other budget considerations are as follows:

a. In Section F, include only items which are to be acquired from outside the small business. On line F5, 
identify the amount of suboontract work necessary for the proposed project. The detailed budget for each subcontract should be described on a separate "Budget Explanation Page".

b. Phase I (and Phase II) grants mey include a profit or fae for the applicant (line $J$ of Appendix D). A profit or fee may also be paid to a subcontractor, that provides goods or services under a subeontract with a granted.

c. If the total cost of the project (Line I plus Line J) exceede the amount requested on the cover page, the grant application must contain information on who will contribute the difference. This difference should be reported on Line $K$ as cost sharing. Line L must match the amount requested on the cover page.

d. Equipment budgets may be included under Phase I (and Phase II). The inclusion of equipment will be carefully reviewed relative to need and appropriateness for the research or R\&D proposed. Equipment is defined as an article of tangible personal property having a useful life of more than two years and an accuisition cost of $\$ 500$ or more. Title to equipment will be vested with the grantes.

e. Budgets for travel funds must be justified and related to the needs of the project.

\subsubsection{Addendum; Documentation of Multiple Phase II Awards}

A small business concern that submits a Phase I grant application and has received mote than 15 Phase II SBIR awards, as totaled from all Federal agencies with SBIR programs, doring the preceding five tiscal years, must document the extent to which it was able to secure Phase II funding to develop concepts resulting from previous Phase II awards. Acoordingly, such small business concerns shall submit, for each Phase II award, the name of the awarding agency, the date of the award, the funding agreement number, the funding amount, the topic or subtopic title, the gmount of follow-on funding, the source and the date that the follow on funding was provided, and the current commercialization staturs. This required intormation will not be counted toward the grant application limitation of 25 pages, and should be prepared on a separate page with the heading
"Addendum-Phase II History." Only one copy is necessary, and it should be attached to the origina] application.

\subsubsection{Certifications}

a. Regarding Lobbying, Debarment, Suspension, and Other Responsibility MattersAppendix $\mathrm{s}$, By signing the grant application cover paye and marking $Y$ in the third eertification, the applicant agrees to these conditions, so Appendix E should not be signed or submitted with the appliantion.

b. Certification Regarding Drug-Free Workplace Requirements-Appendix F. By signing the grant epplication cover page and marking $Y$ in the third certification, the applicant agrees to thess conditions, so Appendix F should not be signed or submitted with the application.

\subsubsection{Checklist}

Complete the Checkliat in Appendix $\mathrm{G}$ and submit one copy with the grant application. The Checklist wi]] not be counted in the 25-page linitistion of the grant application.

\subsubsection{Statistical Information}

Complete the statistical information form (bottom of Appendix G) and submit one completed form with your grant application. This information is required by the Smal] Bustmess Administration for statistical perposes, will not be revealed to the reviewers, and will play no role in the erant application award process. This form will not be coursted in the 25-page limitation of the grant application. 


\section{METHOD OF SELECTION AND EVALUATION CRITERIA}

\subsection{INTRODUCTION}

Phase I grant applications will be judged on a competitive basis in several stages. All will be streened initially by DOE to onsure that they (1) meet stated solicitation requirements, (2) are responsive to the topic and subtopic entered on the cover page (see definition of responsiveness in section 1.4), (3) contain sufficient information for a megningful technical review, (4) are for research or for research and developenent, (5) do not duplicate other previous or current work. Grest applications found to be in compliance with those requirements will be evaluated technically by scientists or engineers to determine the most promising technical and scientific approaches. In the evaluation and handling of grant applications, every effort will be made to protect the confidentiality of the grant application and any evaluations. Each grant application will be judged competitively agejnst the Phase I evaluation criteria (ses Section 4.2) on its own merit. Final decisions will be mede by DOE based on the evaluation criteria and consideration of other factors, such as (1) the amount of Phase III funding received for previous DOE SBIR Phase II projects, and (2) progran balence and needs.

If a written request for a debriefing is received by the SBIR Program Manager within 30 days after the announcement of the tinal selections, an oral debriefing of the grant application will be provided to the small business concern. Neither the identity of reviewers nor their vertatim comments will be disclosed.

Phase If grane applications will be subject to a technical review process similar to Phase I. Grant applications will be judged against Phase II criteria on a competitive basis. Final decisions will be made by DOE based on the evaluation criteria (ses Section 4.3) and consideration of program balance and needs.

\subsection{EVALUATION CRITERIA-PHASE I}

DOE plans to select for award those grant applications judged to be of the highest overall merit, with approximately equal consideration given to each of the following criteris:

1. The eientific/technical quality of the research in the Phase I grant application.
2. The degree of innovation demonstrated by the grant application. Innovation is defined as the process of introducing new ideas into use, or the process of introducing novel nses of existing idess.

3. The qualificationg of the Principal Investigator, other key stafi, and consultants, if any, and the level of adequacy of available or obtaingble instrumentation and facilities.

4. The anticipated benefits, technical and/or economic, of the proposed research (Phase I and Phase II), if successful, with special emphasis on the likelihood that the project will attract further funding for product or process development after the SBIR support expires.

5. The soundness and level of adequacy of the Phase I proposed work plan to show progress toward proving the feasibility of the concept.

In preparing rant applications, applicants should present sufficient evidence to ensure that each criterion is well addressed. Technical reviewers will base their evaluations only on information contafned in the grant application. It cannot be assumed that reviewers are acquainted with the firch or key individuals or any experiments referred to, but not described, in refereed professional journals (i.e., those in which the articles have been subjected to peer review). Relevent journal articles should be identified in the grant application.

\subsection{EVALUATION CRITERIA-PHASE II}

Detailed ingtructions regarding Phase II grant application submission will be sent by $\mathrm{DOE}$ to all Phase I award winners. Listed below are some of the principles on which those instructions can be expected to be based.

A Phase II grant application can be submitted only by a DOE Phase I awardee. It must contain enough information on progress accomplished under Phase I by the time of Phase II grant application submission to enable an evaluation of the project's promise if continued into Phase II. The Phase II erant application will be evaluated for scientific and technical merit and commercial potential based on the 
criteria below. Each item will receive approximately equal woight, except for item one, which will recive twice the value of any other jtem:

1. The scientific/technical quality of the proposed research or $R \& D$ with special emphasis on its degree of innovation.

2. The qualifications of the Principal Investigator and other key personnel to carry out the proposed work and the level of adequacy of available or obtainable instrumentation and facilities.

3. The antiefpated benefits, technical and/or economic, of the proposed research, with special emphasis on the likelihood that the project will attract further funding for product or process development after the SBIR support expires.

4. The degree to which the Phase I objectives were met at the time of Phase II grant application submission.

5. The soundness and level of adequacy of the Phase II proposed work plan to meet the problem or opportunity.

6. The commercial potential of the proposed research or $R \& D$ as evidenced by (a) the small bussiness concern's record of commercializing SBIR or othar resedich, (b) the existence of Phase II funding commitments from private sector or nonSBIR funding sources, (c) the existence of Phase II follow-on funding commitments for the subject of the research, and (d) the presence of other indicators of commercial potential of the idea.
If the small business concern submits a Phase II funding commitment, the commitment should be an additional 20 percent or more of the Phase II funding requested from the DOE in order to receive full credit for criterion 6b. Smaller commitments will receive partial credit. The commitment must be provided either to or by the small business concern during the Phase II project period.

The Phase III follow-on funding commitment mast provide that a specific amount of Phaze HI funds, comparable to that requested from DOT for Phase II, will be made avajlable to or by the small business concern. Smaller commitments will receive partial credit. Commitments must indicate the dates the funds will be made available and contain specific technical objectives which, if achieved in Phase II, will make the commitment exerolsable by the small buginesg concern. The terms cannot be contingent on obtaining a patent because of the length of time this process requires. Both the Phase II and Phase III commiturents must be submitted with the Phase II crant applicetion.

Indicators of commercial potential in evaluation criterion $6 d$ above include evidence that a market exists tor the proposed product or process and the extent to which the proposed product or process would exceed the capabilities or value of other products or processes on the market.

Evaluation of the Phase II grant application may include on-site evaluations of the Phase I effort. The reasonableness of the proposed costs, vis-a-vis the effort to be performed, will be examined.

\section{CONSIDERATIONS}

\subsection{AWARDS}

From this solicitation, $D O E$ expects to award approximately 200 firm, fixed-price Phase I research grants ranging up to $\$ 75,000$ to smal business concerns in fiscal year 1995. Awards are expected to be made no later than September 1, 1995. DOE will announce the names of those firms receiving awards, and successful applicants will then have about six months gfter award to carry out their proposed Phase I effiort.

This solicitation does not obligate DOF to make any awards under either Phase I or Phase II. Awards under the program are subject to the availability of funds. For those grant applications chosen for awards, recipients may incur pre-award costs up to ninety days prior to the effective date of the award; but any pre- 
award expenditures are made at the recipient's risk. Approval of pre-award costs by the Contracting Officer or incurrence by the recipient does not impose any obligation on DOE if an award is not subsequently made, or if an award is made for a lesser amount than the recipient expected.

It is anticipated that one-third to one-half of the Phase I awardees will recejve Phase II awards, depending on the results of the Phase I effort and the availability of funds. The total amount requested must not exceed $\$ 75,000$ for Phase I and $\$ 750,000$ for Phase II.

Phase II is to further develop jdeas originated under Phase I. Specific instructions for the preparation of Phase II grant applications will be sent to Phase I awardees by the DOE at the time of award. Those Phase II applictants who wish to maintain project continuity must submit grant applications no later than 45 days prior to the expiration of the Phase I grant. Buxcessful Phase II applicant may then be issued a srant modification covering a four-month interim period of performance while the Phase II effort. is being negotiated. This modification can be expected to become effective at the completion of Phase I or as soon thereafter as possible. Funding for this interim period is intended to cover the start-up costs of the Phase II effort, and will not exceed a proration of the Phase II effort as determined by the SBIR Program Manager.

Phase II applicants will be requested to provide an estimate of the amount of funding required to cover this interim perjod as part of their Phase II grant application. Should the two parties fail to agree on terms covering the Phase II eftort, allowable costs experienced during the four-month interim pexiod will be paid in accordance with Federal and DOE commercial cost principles. (See FAR, Part 31, and DEAR, Subpart 931,)

The final date for receipt of Phase If grant applications will be May 1, 1996. The period of performance under Phase II will depend on the stope of the effort, but normally will not exceed 24 months. Phase II award decisions will be based on the Phase II grant application and on the evaluation of progress attained under Phase E.

Phase II awards will be in amounts up to $\$ 750,000$, depending on the scope of research or R\&D. Prior to Phase $\mathrm{H}$, the DOE Contracting Officer may request certain organizational, management, and financial information for administrative purposes to assure that the applicant adheres to certain standards applicable to Federal research grants.

\subsection{REPORTS AND PAYMENTS}

Three copies of a fingl report on the Phase I project must be submitted to DOE within 90 days after completion of the Phase 1 effort. The fina] report should include a single-pase project summary as the first page (use form, Appendix B) identifying the purpose of the research, a brief description of the research carried out, the research findings, and the anticipated results/potential commercial applications of the research in a final paragraph. The summary may be published by $\mathrm{DOE}$ and should not conteita proprietery information. The remainder of the report should indicate in detail the project objectives, work carried out, results obtained, and estimates of technica] feasibility.

To avoid duplication of effort, language incorporated in a Phase $\Pi$ grant application to report Phase I progress may be used verbatim in the final report, with changes only to accommodate restits obtained after the Phase If application submission and modifications required to integrate the final report into a self-contgined, comprehensive, and logically structured document.

Details of payment procedures will be disseminated by the DOE Contracting Officer if a grant is issued.

\subsection{RESEARCH INVOLVING SPECIAL CONSIDERATIONS}

If the proposed research activities will involve human subjects at risk or vertebrate animals, the following regalations become effective. Thus, additional information will be required from the applicant.

a. Human Subjects-Guidelines to be used in safeguarding the rights and welfare of human subjects used in research supported by the Department of Energy are contained in $\mathrm{Ch}$. 10, Part 745 of the Code of Federal Regulations (CFR).

b. Animal Welfare-Research work funded by the Department of Energy must be in compliance with the Animal Welfare Aat of 1966, as amended (7 U.S.C. 2131 et seq), (9 CFR Part 1, 2, and 3). 
Additionsl information and certification forms are required if the proposed scientific research involves human subjects or vertebrate animals. You must contact the SBIR Program Oftice, BR-16, U.S. Department of Energy, Wastington, D.C. 20585 [tolephone (301) 908-5867] by February 1, 1995, to request these forma.

\subsection{INNOVATTONS, INVENTIONS, AND PATENTS}

a. Proprietary Information. Information contained in unsuctessful grant applications will remain the property of the applicant. The Government will retain one file copy of each grant application and destroy the remainder. Grant application copies will not be returned to the applicant but they will be destroyed. Public release of information in any grant applieation submitted will be subject to existing statutory and regulatory requirements.

If propriatary information is provided by an applicant in a grant application that constitutes a trade secret. confidential personnel information, or proprietary commercial or financial information, it will be treated in confidence, to the extent permitted by lew, provided this information is clearly marked by the applicant with the term "Confidential Proprietary Information" and provided appropriate page numbers are inserted into the legend printed at the bottom of the cover page (Appendix A), The Government will limit dissemination of such information to within official channels. Any other legend may be unacceptable to the Government and may constitute erounds for removing the grant application from further consideration and without assuming any liability for inadvertent disclosure.

Submisgiong incorporating data affecting the national eccurity will not be accepted for evaluation.

b. Rights in Data Developed Under SBIR Funding Agreements. Rights in technical data, including software developed under the terms of any funding agreement resulting from grant applications subreitted in response to this solicitation, shell remain with the grantee, except that the Oovernment shall have the limited right to use such data for Government purposes and shall not telease such proprietary data outside the Government without permigsion of the grante for a period of not legs than four years from complation of the project from which the data were generated. However, effective at the conclusion of the four-year period, the Govermment shall retain a royelty-free license for Government use of any technical data delivered under an SBIR award whether petented or not and shell be relieved of all diselosure prohibitions.

c. Copyrights. With prior written permission of the Contracting Officer, the ewardee may copyright and publish (consistent with appropriate national security considerations, if any) material developed with DOE support. DOE receives a royalty-free license for the Federal Goverament and requires that each publication contain an appropriate acknowledgement and disclajmer statement.

d. Patents. Sman business concerns may ratain the principal worldwide patent rights to any invention developed with Federal eupport. The Govermment receives a royalty-free license for Federal use, reserves the ritht to require the patentholder to license others in certain circumstances, and requires that anyone exclusively licensed to sell must normally manufacture it domestically. Information regarding patent rights in inventions made with Federal funding by smal] business concerns cen be found in the Code of Federal Regulations, 37 CFR Part 401.

\subsection{COST SHARING, JOINT VENTURES, AND IN-HOUSE WORK}

Cost sharing is permitted for grant applications under this solicitation; however, cost sharing is not required nor will it be an evaluetion factor in the consideration of a Phase I grant application. Federal funding will not exceed $\$ 75,000$ or $\$ 750,000$ for Phase I and Phase II projects, respectively. The amount listed on line L of the butget summary (Appendix D) cannot exceed these amounts, If the cost of the project (lines I+J) exceedg these limits, the applicant must explain who will contribute the difference indicated on line $K$.

Joint ventures are permitted, provided the entity created qualifies as a small business concern in accordance with the definition included in this solicitation (Section 2.3). 
During Phase 1, a minimum of two-thirds of the funded research or analytical effort must be performed by the applicant orcanization. During Phase $\mathrm{H}_{1}$ a minimum of one-half of the funded research or analytical effort must be performed by the apphicant organization.

For both Phases I and II, funded research or analytical effort is defined as the tatal amount of funding designated in the grant application budget (line $\mathrm{L}$ of Appendix D) excluding any purchased or leased equipment, materials, and supplies procured by the small business and its subcontractors.

\subsection{NONDISCRIMINATION IN FEDERALLY ASSISTED PROGRAMS}

In accordance with Title VI of the Civil Rights Act of 1964, P.L, 88-352, the applicant organization responding to thats solicitation must agree to ensure that no person in the United States shali, on the grounds of race, color, national origin, sex, gee, or handicap, be excluded from participation in, be denied the benefits of, or be otherwise subjected to discrimination under any program or aetivity in which the applicant receives Federal assistance from the Department of Energy.

\subsection{GRANTEE COMMITMENTS}

On award of a erant, the grantee will be required to make certain lepal commitments through acceptance of numerous provisions in the Phase I grant. The outline that follows is illustrative of the provisions that will be included in the Phase I grant. This is not a complete list of provisions to be included nor does it contain specific wording of these clauses.

a. Standards of Work. Work performed under the grant must conform to high professional standards.

b. Inspection. Work performed under the grant is subject to Government inspection and evaluation at all remsonable times.

c. Examination of Records. The U.S. Comptroller General (or a duly authorized representative) shall have the right to any directly pertinent records of the grantee involving transactions related to this grant.

d. Suspension and Termination. The Government may suspend or terminate a grant for ceuse on the basis of noncompliance or debarment of the awardee. e. Disputes and Appeals. Any dispute concerning the grant which cannat be resolved informally shall be decided by the Contracting Officer with right of appeal.

f. Affirmative Action for Veterans. The erantes will not discriminate against any employee or applicant for employment because he or she is a disabled vetergn.

g. Offieials Not to Benefit. No member of or delegate to Congress shall benefit from the grant.

h. Covenant Against Contingent Fees. No person or asency has been employed to soljeit or secure the grant upon an understanding for compensation except bona fide emplayees or commercial agencies maintained by the grantee for the purpose of secming business.

i. Gratuities. The grant may be terminated by the Government if any gratuity has been offered to any representative of the Government to secure the grant.

\subsection{ADDITIONAL INFORMATION}

a. This solicitation is intended for informational purposes and reflects current planning. If there is any inconsistency between the information contained herein and the terms of any resulting SBIR award, the termg of the award shall control.

b. Before issuing an SBIR award, the Government may request the applicant to submit certain organizational, management, personnel, and financia] information to assure responsibility of the applicant.

c. Unsolicited grant applications will not be accepted under the SBIR program in either Phase I or Phase II. 


\section{SUBMISSION OF GRANT APPLICATIONS}

\subsection{NUMBER OF COPIES}

The following must be submitted:

I original application which includes:

a. Cover Sheet (Appendix A),

b. Pruject Summary (Appendix B),

c. Main Text as required in Section 3.4.2,

d. Budget Form (Appendix D),

Note: Signatures are required on the Cover Page (Appendix A) and the Budget Form (Appendix D).

7 additional copies of the application

8 additional copies of the Project Summary (Appendix B)

1 completed Check]ist and Statistical Information form (Appendix G)

1 addendum, "Documentation of Multiple Phase II Awards" (if appropriata)

Grant applications submitted as First Class, Registered Majl, Certffied Mall, or Two-Day Priokity Mall through the U.S. Postal Service, must be addressed to:

SBIR PROGRAM MANAGER (ER-16)

U.S. DEPARTMENT OF ENERGY

WASHINGTON, D.C. 20585

Please use the following address when submitting grant applications by any other method including Overnight Postal Service:

SBIR PROGRAM MANAGER (ER-16)

U.S. DEPARTMENT OF ENERGY

INTERSTATE 270 AND ROUTE 118

19901 GFRMANTOWN ROAD

GERMANTOWN, MD 20874

(301) 908.5867

Phase I grant applications hand carried by the applieant may be delivered to: U.S. Department of Bnergy, 19901 Germantown Road, Germantown, MD.

Applications will not be accepted by the Department at its Independence Avenue SW, Waskington, D.C. address.

If a grant application ackmowledgement with the grant application number endorsed on it is not received from
DOE within three weeks following the closing date of this solicitation, the applicant should telephone the SBIR Program Office promptly at (90) 909-5867.

\subsection{DEADLNE FOR RECEIPT OF GRANT APPLICATIONS}

a. Any grant application received after 5:00 p.m. BST on Wednesday, March 1, 1995, will be considered late unless it was sent by the U.S. Postal Service's regiatered ox certified mail not later than February 22, 1995. Since the postmark will be the evidence on which the decision is made, it is incumbent on applieants to assure themselves that the postmark is clear and easily legible; hand cancellation is suggested. All other methods of delivery of grant applieations will be constidered late if they are received after $5: 00 \mathrm{p}$-m. EST on Wednesday, March 1, 1995. Late grant applictations will not be eligible for award and will be declined without a review. Applications may not be subristed by telefax.

b. Modifications to grant applications that are intended to be incorporated in the review/award process will be accepted only if received by the deadifine, and are clearly marked as modifieations.

c. Modifications by suecessful applicants during the process of negotiation will be considered only if it is determined that they make the grant application more favorable to the Government.

d. Grant applications may be withdrawn by a written notice received at any time prior to award. The Government will retain one file copy.

\subsection{PHYSICAL PACKAGING}

Do not use special bindings or covers. Staple the pages in the upper left hand coraer of each grant application. Secure packaging is mandatory. The Department cannot be responsible for the processing of grant applications damaged in transit. 


\section{SCIENTIFIC AND TECHNICAL INFORMATION SOURCES}

Applicants may want to obtain scientific and technical information related to their proposed effort as background or for other purposes. Sources of this information are listed in the bibliographies of each topic in Appendix 1.

\subsection{NATIONAL TECHNICAL INFORMATION SERVICE}

Reports resulting from Federal research and those received from exchange agreements with foreign countries and international agencies are available to the public in both paper opy and microfiche through the National Technical Information Service (NTIS). They may be ordered by telephone for dispatch through regular mail for a nominal fee from:

NTTS

U.S. Depertment of Commerce

6285 Port Royal Road

Springfield, VA 22161

(708) $487-4650$

For expedited servite, call toll-free 1-800-\$53-6847. Rush service (dispatched within 24 hours by First Class Mail), second day air, and express sarvice are each available for an additional cost.

Alterratively, microfichs of unclessified, unlimited DOE reports is available for use by the public free of charge in Government Printing Office depository collections. More than 1,400 public, college, and university libraries around the country are designated as U.S. Depository Libreries. Check with a local public library. Most libraries participate in on inter-library loan service whereby one may request copies of an unavalable publication from another library.

\subsection{DOE OFFICE OF SCIENTIFIC AND TECHNICAL INFORMATION}

DOE maintains an Office of Scientific and Technical Information (OSTI) which collects and disseminates both DOE-originated and worldwide scientific and technical literature in subjects of interest to DOE researchers. This information is available to the general public.
The Energy Data Base, containing over 2 mitlion scientific and technical references, is available from:

DIALOG Information Services, Inc. $1-800-334-2564$

STN International

$1-800-753-4227$

In addition, OSTI has developed an on-line Superconductivity Information System (SIS) which includes a bulletin board and three date bases Preprints Database, Work-in-Progress Database, and Energy Database. SIS provides information and realtime communications for government program offices, researchers, industry, and academia on a dajly basis. SIS is accessible through:

U.S. Department of Enersy

Office of Seientific and Technical Information

P.0. Box 62

Oak Ridge, TN 37881

\subsection{OTHER SOURCES}

Literature and database sesrches for abstracts, publications, patents, lists of Federal research in progress (the FEDRIP databese), and names of potential constutants in the specific research area can be obtained at good technical libraries \{especially those of universities), from some state organizations, and from the organizations listed below.

Rural Enterprises, Inc.

$1-800-658-2823$

Mid Atlantic Technology Applications Center 1.800 .257 .2725

NASAFar Weat Rogional Technology

Transfer Center

1.890-642-2872 in California

1-800-872-7477 outside California

Southerm Technology Applications Center

$1-800-472-6785$ in Floride

1-800-225-0308 putside Florida 


\section{U.S. DEPARTMENT OF ENERGY \\ SMALL BUSINESS INNOVATION RESEARCH SOLICITATION NO. DOEIER-0629 \\ COVER PAGE}

APPENDX A

DOE USE ONLY

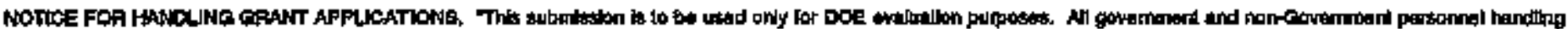

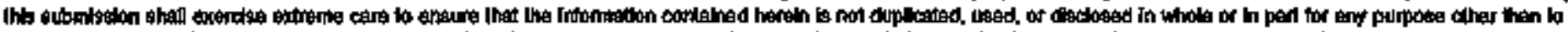

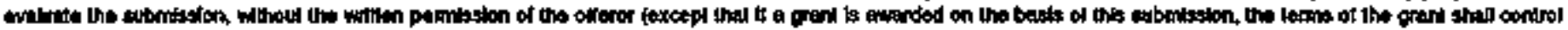

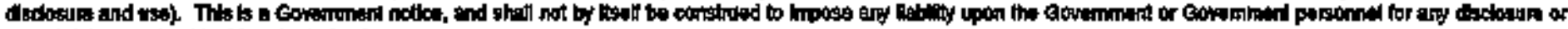

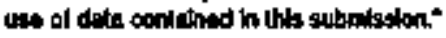

Topie No. (1-44)

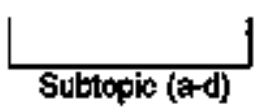

PROJECT TITLE:

FIFU NAME:

MALING ADORESS:

ciTr:

STATE:

ZIP:

(Finas provide extenderd ap oode.)

AMOUNT RECUESTED:

(Not to expoed $\$ 75,000)$

ANSWER

$Y$ Presi ORN Wh

GERTIFICATONS AMD QUESTIONS

The above applieant organization certifies that it is $\mathbf{1}$ smeil business and mebts the defisition stated in Section 2.3.

A minimum of two-thirds of the funded research or anabytcal etfort wal be performed by the appllcant organlzation (see Section 5.5).

The applicant small busimess wilh comply with the provisions regarding* (1) lobbying, (2) debarment, suspension, and oiher responsiblity matters, and (3) drug-tree werkplace requirements, (See Appendx $E$ and Appendix $F$.) Inability to certily to any or all statements requires explanation.

The applicant small business has provided the necessary information requested in Section 3.4 .4 it has received more tran 15 Phase II SBIR awards in the preseding five fiscal years.

The applicant small busmess has sent or plans to send this application or a similar one to another Federal agency. If "yes", the applicetion includes the required Iniomation requesiled in Sigction \$,4.2.J.

If the proposed project does not result in an award, the applicant organizetion pamits the govemmand to disclose the like and techrical ebstract of the applicalion, and the name, address, and telephone number of the business official to any inqulring perties.

Principal Investgaior (See Reculiemento in Sec. 1.5)

TYPE NAWE, Indicate Mr., Mrs., Ms.., Dr.

Thto:

Telephorie No.

Signature of Principe: Imvestigetor

\section{Corporake Busineos Certifying Ofitelel}

TYPE NAMEE, Indicate H., Mrs., Ms., Dr.

Trite:

Tolophomino.

Silgnifine of Corporater Business Certifying Official Dato:

PROPAIETAPY NOTHE (OF APPLICABLE, EES EETION $\$$.A

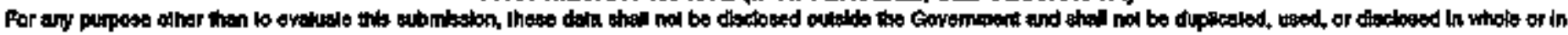

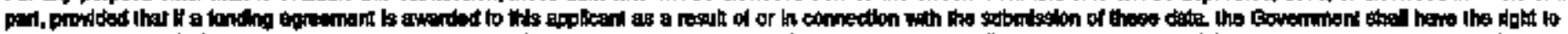

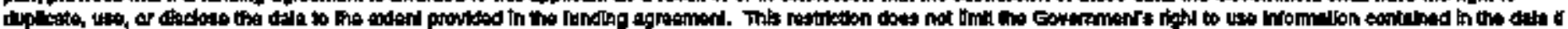

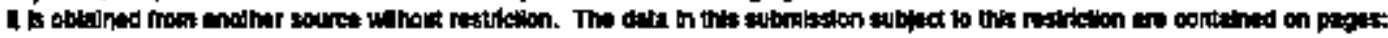




\section{INSTRUCTIONS FOR COMPLETING APPENDIX A}

1. Topic Number--Provide the appropriate numerical designator of the technical topic (one of the 44 listed in Appendix $\mathrm{H}$ ) to which you are submitting your grant application.

2. Subtopic-Provide the appropriate alphabeticaI character designating the subtopic, within the technical topic, to which you are submitting your crant application.

3. Amount-Must not exceed $\$ 75,000$. Grant applictions requesting more than $\$ 75,000$ will be declined without further review.

4. Project Title-Should reflect the substance of the project and must be limited to 120 characters and spaces. Do not use the solicitation's topic or subtopic title.

5. Firm Name-Enter the name of the company or individual submitting the grant applicafion. If a joint venture, enter the ngme of the company chosen to negotjate and receive the grant. If the name exceeds the space provided, please abbreviate it.

6. Mailing Address-Enter mailing addregs.

7. State-Enter two-letter state abbreviation.

8. Zip Code-Enter nine-digit code.

9. Certifications and Questiong-Enter $Y$ for yes and $N$ for no in response to each of the statements or questions on the cover page.

10. Fndorsements-Must be completed and signed by both the Principal Investigator and the Corporate/Business Official empowered to make contractual commitment on behalf of the firm. Both entries must be completed and signed even if the functions of the Principal Investigator and the Corporate/Business Official are performed by the same individual. Desigmate one copy of the grant application as the original and have original signatures appear on the cover page (Appendix A) and the budget summary (Appendix D) of that copy.

11. Proprietary Notice (hottom of cover page)-Should be completed, if applicable. 


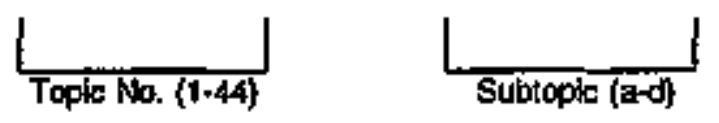

FIRM NAAE, ADDAESS, TELEPHONE NUHABER:

TITLE OF PAOJECT:

NAME AND TITLE OF PRINCIPAL INVESTKBATOR:

TECHNICAL ABSTHACT (Lmik to space provided.)

KEY WORDS:

ANTICIPATEO RESULTSIPOTENTIAL COMHERCIAL APPLICATIONS as described by the applicant. (Limit to space provided). 


\section{INSTRUCTIONS FOR COMPLETING APPENDIX B}

1. Name, Address, and Telephone Number of Applicant-- Enter the firm ngme, the mailing address, and the telephone number as entered on the grant application cover page, Appendix A.

2. Title of Project-Finter the same title as entered on the grant application cover page, Appendix A.

3. Name and Title of Principal Investigator-Enter the same name and title as shown on the grant application cover page, Appendix A.

4. Technical Abstract-Provide a summary of your proposed project. It should be a concise statement of the proposed effort for Phase I. limited to the space provided.

5. Key Words-Provide key words descriptive of the project and useful in ideatifying the subject matter of the technology, research thrust, or potential uses of the proposed effort.

6. Anticipated ResultsPotential Commereial Applications-Summarize the results and commercial applications that can be anticipated if the project is carried over into Phase II and beyond. Limit to the space provided. 


\section{APPENDIX C}

\section{SAMPLE PROJECT DESCRIPTION}

\section{Project Objective}

The applicant shall investigate the electrocatalytic production of styrene from ethylbenzene in solid electrolyte fue] cells. The effort is directed toward defining optimal operating conditions for achieving high yields of styrene with simnltaneous electric energy generation.

\section{Project Description}

The work to be performed consists of the following tasks:

2.1 Construction of tubular zirconia fusl cells with a platinum cathode and an iron oxide or platinum anode. Both anode materials are quite promising and a decision between the two will be made after preliminary rens.

2.2 Measurament of the styrene cell activity and yields as a function of velocity, temperature, and injet concentration of ethylbenzene and external resistive load.

2.3 Measurement of the cell electric power output and overpotential as a function of the operating parameters described in 2.2.

2.4 Preliminary engineering and economic analysis according to the results of 2.2 and 2.3 .

2.6 Final Rejort Preparation

\section{Performence Schedule}

Task 2.1 completed two monthe after start of work.

Task 2.2 and 2.3 completed four months after start of work.

Task 2.4 completed five months after start of work.

Task 2.5 completed six months after start of work.

\section{Reporting Requirement}

The applicant shall provide a Final Report containing the data from the experiments performed according to Tasks 2.2 and 2.3 along with analyses and conclesions based on these data. 


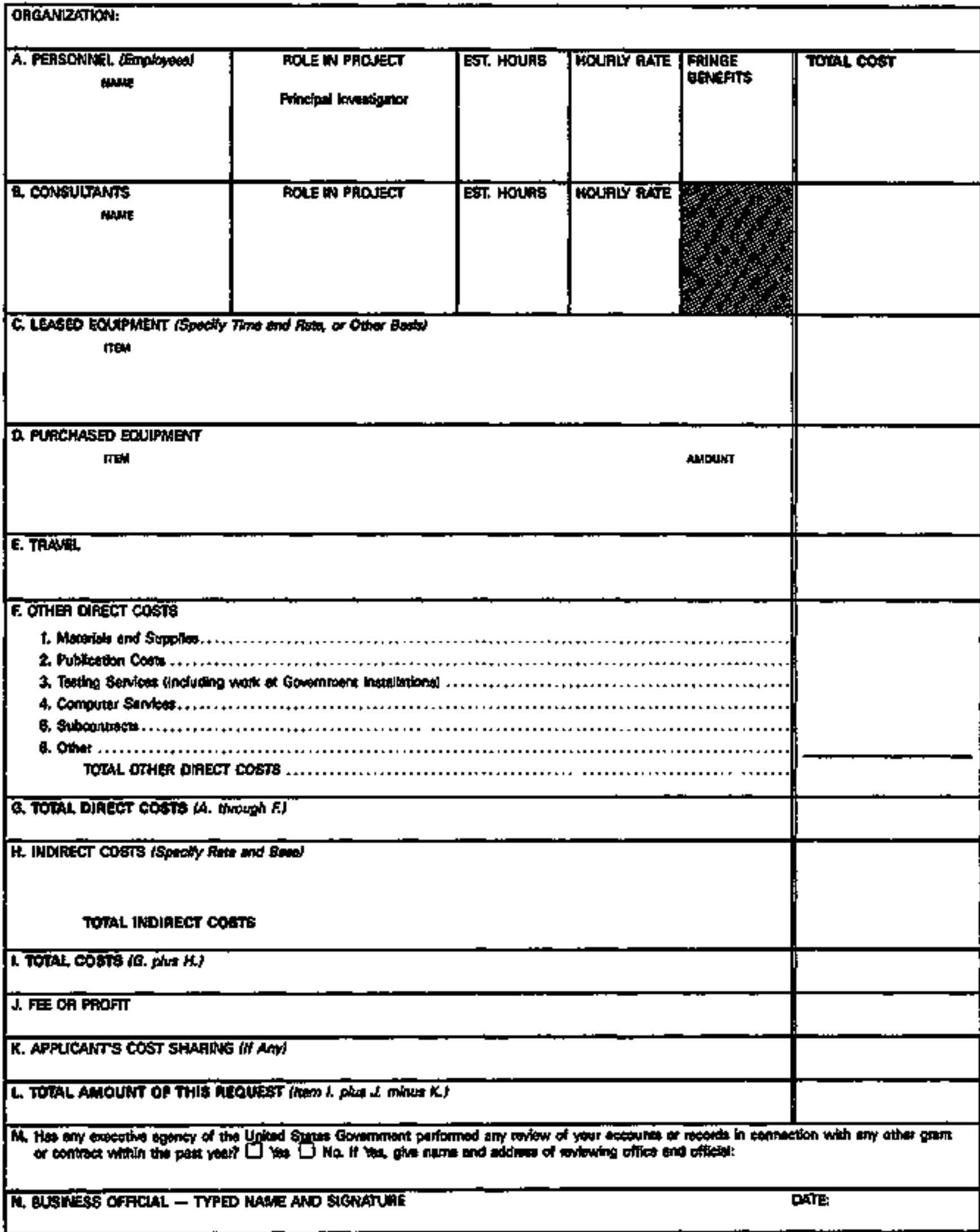




\section{INSTRUCTIONS FOR SBIR GRANT APPLICATION BUDGET}

\section{General}

a. Each grant application must contain a completed and signed budget form.

b. If the information requested does not, fit in the spaces provided, use an additional page and give it the heading "Budget Fiplanation Page".

\section{Budget Line Items}

The following is a brief outline of the information required:

Lines A and B, Labor: List the key personnel and consultants by name and function ar role in the project. Other direct personnel need not be naned, but their role, sueh as "technician", and total hours should be entered. Support personnel should be included in line H. Fringe benefits should be cakculated to cover all direct labor overhead costs, including Social Security, pensions, and insurance, and entered as a total dollar amount. You can use an established labor owerhead rate if you have one.

Lines C and D, Equipment: Items costing over $\$ 500$ and exceeding 2 years of useful bife should be listed. Lesser items can be shown in line F.1.

Line F, Travel: Itemize by destination, type, period, and cost for both steff and consultants.

Line F, Other Direct Costs* Entries exceeding \$500, and other items requining an explanation, should be detailed on a "Budget Explanation Page". If a subcontract includes costs for equipment, materials, or supplies, these should also be noted on a "Budget Explanation Page." (See Section 3.4.3.)

Line G, Total Direct Costs: Enter the sum of lines A throngh F.

Line H, Indirect Costs: If you have an established G\&A (General and Administrative) rate you may cite it. Otherwise you should include all indirect costs such as facilitjes, shared equipment, utilities, property taxes, and support staff for the period of the project.

Line I: Enter the total amount of the proposed project.

Line J: Self-explanatory.

Line K: Enter the amount which the applicant or other private sector or non-\$BIf sources are committing to the project. For Phase $\Pi_{2}$ this amount, if any, will be used to evaluate criterion $6 \mathrm{~b}$ in Section 4.3 of the solicitation.

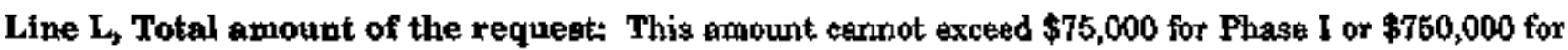
Phase II.

Line M, Federal Audit: If DCAA or another Federal agent has audited your accounts in connection with a Federa] grant or contract, please enter the information requested, and use the established rates in lines A. and $\mathbf{H}$.

Line N, Business Official: A signature of someone with the authority to commit the company must, be given.

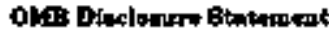

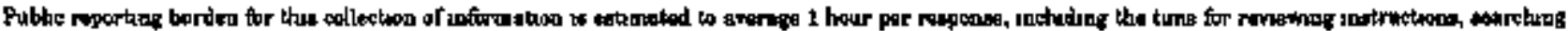

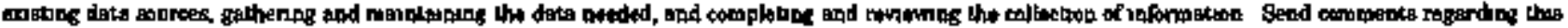

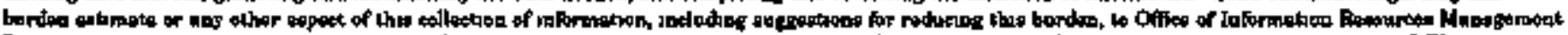

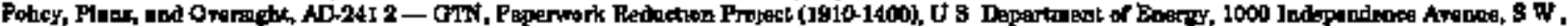

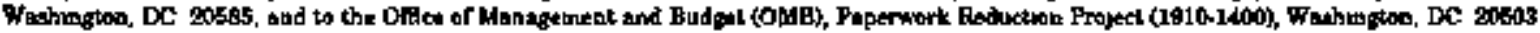




\section{CERTIFICATION REGARDING LOBBYING}

By signing and submitting this application the organizational applicant certifies to the best of its knowledge and belief, that it and its principalo believe that:

1) No Pederal appropriated funds have been peid or vill be peid, by or on behalf of the underejgned, to any person for influtencing or attempting to influence an officer or employes of any agency, a Member of Congress, an offloer or employes of Congrese, or an employee of a Member of Congress in connection with the awarding of any Federal contract, the making of any Federal grant, the making of any Federal loan, the entering into of any copperative agreement, and the extenston, continuation, renewal, annenduent, or modiffeation of any Federal contract, Erant, loan, or cooperative ogreement.

2) If any funds other than Federal approptiated funds have been paid or will be patid to eny person for influencing or attempting to influence an officer or employes of any agency, a Member of Congress, an offeer ar employee of Congress, or an employee of a Member of Congress in connection with this Fedieral contract, grant, loan, or copperative agreement, the organizational applicant shall complete and submit Standard Form-L,LL, "Diaciosure Form to Report Lobbying" in accordance with jte inetructions.

3) The organizational applicant ghall require that the language of this certification be included in the award dacuments for all sulbawards at all tiers (tncluding subcontracts, gubgrants, and contracts onder grants, loens, and cooperative agreements) and that all subrecipients shall certify and disclose accordingdy.

This ortification is a matertal reprentation of fact upon which reliance was placed when this traneaction was made or entered into. Submission of this certification is a prerecpuitite for making or entering into this transaction imposed by section 1352, títle 31, U.S. Colle. Any person who fails to fils the required certivication ehalt be subject to a civil penalty of zot less thas $\$ 10,000$ and not mare than $\$ 100,000$ for each such failure.

\section{CERTIFICATION REGARDING DEBARMENT, SUSPENSION, AND OTHER RESPONSIBILTY MATTERS - PRIMARY COVERED TRANSACTIONS}

By signing and submitting this application-

1) The organizational applicant certifies to the best of its bowpledge and belief, that it and its principalg:

a. Are not presently debarred, suepended, proposed for debarment, declared tneligible, or volnntarily excladed fiom covered transaction by any Federal department or agency;

b. Have not within a three-year pariod preceding this application been convicted or had a civil judgenent repdered againat them for commiseion of frand or a criminal offense in connection with abtaining, attempting to obtain, or perforrning a public (Federal, State, or local) trangaction or contract under a pnblic tranescetion; violation of Federal or State anti-trust statues or commissajon of emberzlement, theft, forgery, butbery, faleffication or destruetion of recorde, makng false statements, or recoiving atolen property;

c. Are not presently indicted or otherwise criminally or ctvilly charged by a government entity (Federal, State, or local) with commisston of any of the offenses enumerated in paragraph 1.b. of thie certification; and

d. Have not within a three-year period preceding this application had one or more public traneactions (Federal, State, or local) terminated for cause or default.

2. Where the Prospective primary participant is unable to certify to any of the statements in this certification, such proepective participant shall attach an explanation to this application. (The explanatory attachment will not be counted in the 25-page linitation.) 


\section{CERTIFICATION REGARDING DRUG-FREE WORKPLACE REQUIREMENTS}

This certification is required by the Drug-Free Workplace Act of 1988 (Pab. L. 100-690, Title V, Subtitle D) and is implemented through additions to the Debarment and Suspension regulations, published in the Federal Register on Japrary 31, 1989.

By signing and submitting this application the organizetional applicant certifles that ft will provide a drugfree workplace by:

(a) Publishing a statement notifying employees that the untawftl manufacture, tiatribution, dispensing, possession, or use of a controlled substance is prohibited in the granteg's workplace and specifying the actions that will be taken agajnst employees for violation of sach prohibition;

(b) Establishing a drug-free awarenese program to inform employese about-

(1) the dangers of drug abuge in the workplace;

(3) the granted's policy of mainteining a drug-free workplecs;

(3) any available drug counseling, rehabilitation, employes assigtance programs; and

(4) the penalties that may be imposed upan employees for drug abuse violations occurring in the workplace;

(c) Making it a requirement that each employee to be engaged in the performance of the grant be given a copy of the etatement required by paragraph (a);

(d) Notifying the employe in the statement required by paragraph (a) that, as a condition of employment under the grant, the employes will-

(1) abtde by the terms of the statement; and

(2) notify the employer of any criminal drag atatute conviction for a violation occurring in the workplece not later than tive days after such convicion;

(d) Notjfying the agency withto ten days after receiving notice under subparagraph (d)(2) from an employee or otherwise receiving actual notice of such convietion;

(f) Taking one of the following actions, within go days of recesving notice under eubparagraph (d)(2), with respect to any empioyee who is so convicted-

(1) taking appropriate personnel action againgt such on euployee, up to and including terwination; or

(2) requiring euch employes to participate satisfactorily in a drug abuse aesistance or rehabilitetion progrem approved for sucb purposes by a Federal, State, or local health, lew enforcoment, or other appropriate agency;

(g) Meking a good faith effort to maintain a drug-free workplace through implementation of paragraphe (a), (b), (c), (d), (a), and (f).

An applicant who is an individual certifies that, as a condition of the grant, he or she will not engage in the unlawful manufacture, distribution, dispensing, posisession, or nos of a controlled substance in conducting any activity with the grant. 


\section{CHECKLIST}

Applicant:

Project:

Please complete the checklist and peper clip (one copy only) to the cover sheet of the priginal (signed) copy of the grant application.

\section{DOES THE APPLICATION SATISFY THE FOLLOWDNG REQUIREMTNTS:}

$\checkmark \quad$ One, and only one, topic from Appendix I identified on the cover poge.

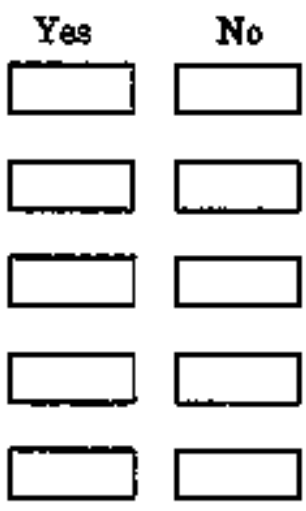
in Appendix $\mathrm{D}$ exceeds $\$ 76,000$, the application must explain who will contribute the difference.

$\checkmark \quad$ Abstract contains no proprietary information and does not exceed space provided on the Project Summary Page (Appendix B).

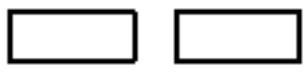

$\checkmark$ Main text (technical content) is included as requested in Section 3.4.2.

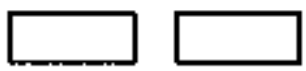

- Application, including all enclosures, not more than 25 pages. Hovrever, Appendix $G$ and the Documentation of Multiple

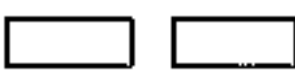
Phase II Awards (Section 8.4.4) will not be included in the 25-page count.

No pages other than $81 / 2 " \times 11^{\prime \prime}$.

No type smaller than (1) 12 point for proportionally spaced fonts and (2) 12 characters per inch (elite) for non-proportionally spaced fonts (except as legends on rectuced drawings, but not tables).
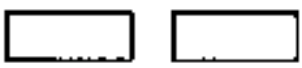

$\checkmark$

$\checkmark$ A minimum of $2 / 3$ of the research or analytical effort will be performed by the small business. (See Sections 3.4.3 and 6.5).

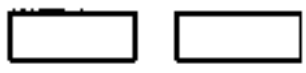

ATHENTION: GRANT APPLICATIONS NOT MRETNG ALL OF THE ABOVE REQUTREMKNITS WLL BE DECLINED WTTHOUT PORTHER ACTION.

\section{STATISTICAL INFORMATION}

The proposing firm certsfies that it is a socially and economfcally disadvantaged small business concern. (See Section 2.4)

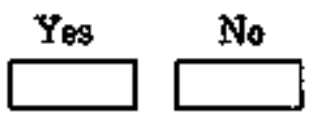

The proposing firm certifies that it is a woman-owned organization small business concern. (Bee Section 2.5.) 


\section{SUBJECT INDEX FOR SECTIONS 1-7 AND APPENDICES A-G}

Eubiect

Acknowledgement of Receipt of Application . . . 1.6, 6.1

Administrative Requirements . . . . . . . 3.3,6.1, Appendix $G$

Anjmal Weifare $\ldots \ldots \ldots \ldots \ldots \ldots \ldots \ldots \ldots .3 . b$

Awards, Phase I (amounts and duration) . . . 1.2, 5.1

Awards, Phase II (amounts and duration) $\ldots \ldots, 1,2,5.1$

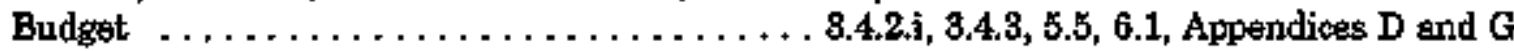

Certifications $\ldots \ldots \ldots \ldots \ldots \ldots \ldots \ldots \ldots$ 3.3, 3.4.5, 5.3, Appendjces A, E, F, and G

Civil Pights Act $\ldots \ldots \ldots \ldots \ldots \ldots \ldots \ldots \ldots .6$

Classitied Information $\ldots \ldots \ldots \ldots \ldots \ldots \ldots \ldots .4$

Commercial Potential $\ldots \ldots \ldots \ldots \ldots \ldots \ldots$ 3.4.2.b.2, 4.3.6

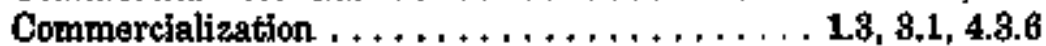

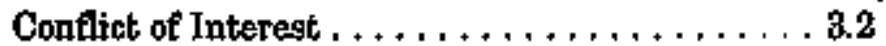

Consaltants . . . . $\ldots \ldots \ldots \ldots \ldots \ldots \ldots \ldots$ 3.1, 3.4.2.i, Appendix D

Contact with DOE . . . . . . . . .

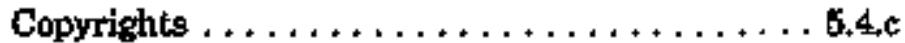

Cost Sharing $\ldots \ldots \ldots \ldots \ldots \ldots \ldots \ldots \ldots$ 5.5, Appendix D

Cover Page . . . . . . . . . . . . Appendix A

Deadlines for Submission . . . . . . . . . . 6.2

Debriefings $\ldots \ldots \ldots \ldots \ldots \ldots \ldots \ldots \ldots \ldots, 4.1$

Declination of Application $\ldots \ldots \ldots \ldots \ldots \ldots, 14,8,1$

Disclosure of Grant Application Information ... 3.2, 5.4, Appendix A

Duplicate Applications $\ldots \ldots \ldots \ldots \ldots \ldots \ldots$ 1.4, 4.1

Eligibility $\ldots \ldots \ldots \ldots \ldots \ldots \ldots \ldots \ldots \ldots 1.4$

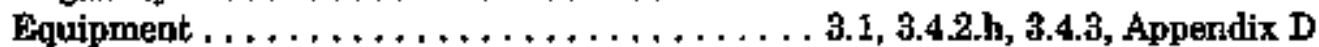

Evaluation of Grant Application $\ldots \ldots \ldots \ldots \ldots$. 3.1, 3,2

Evaluetion Criteria ............... 1.3, 1.5, 3.1,4

Facilities . . . . . . . . . . . . . .4.2.h

Feasibility of Proposed Work $\ldots \ldots \ldots \ldots \ldots .1$

Fee $\ldots \ldots \ldots \ldots \ldots \ldots \ldots \ldots \ldots \ldots \ldots \ldots \ldots$ 3.4.3.b, Appendix $\mathbf{D}$

FLC Locator $\ldots \ldots \ldots \ldots \ldots \ldots \ldots \ldots$

Foreign Involvement $\ldots \ldots \ldots \ldots \ldots \ldots \ldots \ldots \ldots$. $\ldots \ldots$

Format of Grant Application $\ldots \ldots \ldots \ldots \ldots .4$

Human Subjects $\ldots \ldots \ldots \ldots \ldots \ldots \ldots \ldots \ldots$ 5.3.a

Innovation $\ldots \ldots \ldots \ldots \ldots \ldots \ldots \ldots \ldots \ldots .2 .3 .1,4.2 .2$

Instructions--Application Preparation $\ldots \ldots \ldots, 3$

Inventions . . . . . . . . . . .

Joint Venture $\ldots \ldots \ldots \ldots \ldots \ldots \ldots \ldots \ldots \ldots 2.7,5.5$

Literature Surveys . . . . . . . . . . . . . 3.1

Location of Work to be Performed ......... 1.4

Mailing and Address Information ... . . . . 6.I, 6.2

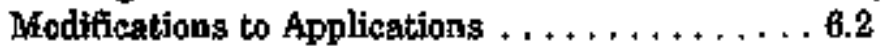

Multiple Applications . $\ldots \ldots \ldots \ldots \ldots \ldots \ldots \ldots$ 1.4, 3.4.1.a, 3.4.1.b, 3.4.3

NTIS $\ldots \ldots \ldots \ldots \ldots \ldots \ldots \ldots \ldots \ldots .1$ 
Objectives of \$BLR program $\ldots \ldots \ldots \ldots \ldots \ldots 1.1,1.3$

Objectives of Phase $1 \ldots \ldots \ldots \ldots \ldots \ldots$

Objectives of Phase II $\ldots \ldots \ldots \ldots \ldots \ldots \ldots$..2

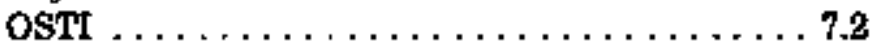

Packaging of Applications . . . . . . . . . 6.3

Page Requirements $\ldots \ldots \ldots \ldots \ldots \ldots \ldots \ldots$ 3.3, 3.4.6, 3.4.7, Appendix $G$

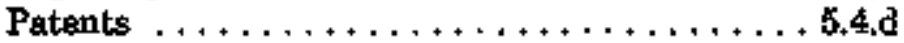

Phase I Awards (amounts \& duration) $\ldots \ldots \ldots 1.2,5.1$

Phase II Awards (amounts \& duration) . . . . 1.2, 5.1

Pre-Award Expenditures . . . . . . . . . . 5.1

Previously Funded or Pending Applications . . . 1.4, 8.4.2.j

Principal Investjgator $\ldots \ldots \ldots \ldots \ldots \ldots \ldots$ 1.5, 3.4.2.g, 4.2.3, 4.3.2, Appendjces A and B

Profit $\ldots \ldots \ldots \ldots \ldots \ldots \ldots \ldots \ldots \ldots \ldots \ldots$ 3.4.8, Appendix D

Project Description $\ldots \ldots \ldots \ldots \ldots \ldots \ldots \ldots$ 8.4.2.e, Appendix $C$

Project Summary . . . . . . . . . . . . . . . . 3.4.1.b, 5.2, 6.1, Appendjees $B$ and $G$

Proprietary Protection ............. 3.2, 3.4.1.b, 5.4, Appendices A, B, and G

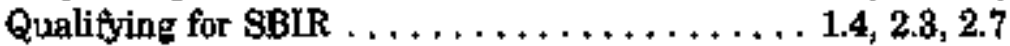

Requirements of Grant Application $\ldots \ldots \ldots, 3$

Research and Development $\ldots \ldots \ldots \ldots \ldots \ldots 2.1$

Responsiveness to Topic . . . . . .

Review of Grant Application $\ldots \ldots \ldots \ldots \ldots 3.2,4,2,4.3$

Selection of Awards $\ldots \ldots \ldots \ldots \ldots \ldots \ldots 1.6,4,5.1$

Signatures $\ldots \ldots \ldots \ldots \ldots \ldots \ldots \ldots \ldots \ldots \ldots+3.4 .3,3.4 .5$, Appendices A, D and $G$

Similar Submissions $\ldots \ldots \ldots \ldots \ldots \ldots \ldots \ldots, 3.4 .2 . \mathrm{j}$

Small Business Concern $\ldots \ldots \ldots \ldots \ldots \ldots 1.4,2.3,2.4,2.5,2.7,5.5$, Appendices $A$ and $G$

Small Business Certifying Official . . . . . . Appendices A and D

Statistical Information Form $\ldots \ldots \ldots \ldots \ldots$ 3.4.7, Appendix $G$

Subcontracts $\ldots \ldots \ldots \ldots \ldots \ldots \ldots \ldots \ldots .6 \ldots \ldots .4 .2 .1$, Appendix D

Technical Content of Application $\ldots \ldots \ldots \ldots .3 .1,3.4 .2,4.1,4.2,4.8 .1$, Appendix $G$

Topic and Subtopic $\ldots \ldots \ldots \ldots \ldots \ldots \ldots \ldots$ 1.4, Appendices $A, B$, and $G$

Type Size Requirements $\ldots \ldots \ldots \ldots \ldots \ldots$ 3.3. Appendix $G$

Unsolicited Applications $\ldots \ldots \ldots \ldots \ldots \ldots \ldots \ldots .5 .6$

Withdrawals $\ldots \ldots \ldots \ldots \ldots \ldots \ldots \ldots \ldots \ldots .2 . d$ 
APPENDIX 1

\section{TECHNICAL TOPIC DESCRIPTION}

The technical topic degcriptions for this solicitation are given below. The text in the first section of each topic eives general and backsround information for the topic. Within a topic, where there are subtopics, a grant application must respond specifically to the description given in one subtoptc and not just to the general description at the beginning of the topic; it must comply, however, with any restrictions and exclusions contained within that general description.

\section{NOVEL MATERIALS FOR SUSTAINABLE ENERGY DEVELOPMENT}

This topic provides small businesses with an opporturity to propose substantially novel research in edvanced materials for use in two areas that could drectly influence the Nation's enercy resources and utilization. DOE is interested in novel, energy-related ideas that are substantiated by proven scientific principles, and that indicate clearly that the jdea has a reasonable chanee of success either in demonstrating the validity of a pre-commercialization technology or in succeeding as a commercielly viable commodity or process. The jdea must be environmentally acceptable. Before submitting a grant application nuder this topic, applicants should consider other technical topie degeriptions, such as those under Chemical Soiences Research, Improved Materials for the Pulp and Paper Industry, Measurement and Characterization of Materials in Civilian Nuclear Reactors, Improved Technology for Obtaining Recyclable Materials from Municipal Solid Waste, High Temperature Supereonductivity for Energy Applteations, and Lishtwetght Compostte Materials for Automotive Struchures, to assure that the application is submitted to the most appropriate technical topic.

Grant applications are invited only in the following gubtopics: a. Novel Materiale for Direct Energy Applica. tions or for Replacement Produots or Components-Materials regearch is rapidly producing new materials, such as sophisticated thoranal manegement materials, catelysts, or membrane technology for direct methanol fuel cells, as well as new approaches to synthesizing and processing materiaks, and designing single or composite materials with characteristics tailored to specific energy-related applications. Such methods open up an arens for inmovation and discovery for new energy-efticient synthesis and processing and for novel ideas to fabricete new or substitute products or components for eneroy applications such as for enerey storage or conversion. Some novel materials can be derived from renewable resources. Reference 3 describes a broad survey of needs and opportunities for innovation, including materials directly epplied to enerey generation, storage, conversion, delivery, and use. This subtopic focuses only on materials for direct energy-related applications.

Grant applications are solicited for novel approaches to create: (1) materials or surfaces applied to specific replacement parts or tomponents that demonstrably and significantly inprove energy efficiencies or reduce environmental impacts in the generation, conversion, delivery, and use of energy; and (2) symthesis, processing, or fabrication methods for the production of such energy-related materials or components for which the method would increase the energy efficiencies significantly or demonstrably reduce environmenta] impacts. Grant applications should explicitly focus on the design or processing of materials or components for a particular application to replace a specified process, product, or component that presents a limiting factor in current processes or technology. For example, new thermoelectric materials could be fabricated in ruultilayered arrangements for significantly enhanced figures of merit and applied to a cooling component or unit; or superplastic forming could drastically reduce energy and time costs of a speciffe fabrication method of energy-related parts or components. Grant applications that fall within the description of topic 6 , Ifigh Temperature Superconductivity for Energy 
Applications, should be submitted ander that topic. Grant applications involving high temperature superconductors in other ways should be considered for submission under this suptopic.

Applications that are oriented toward research that would yield sumall or incremental improvements will not be constdered under this subtopic, regardless of their inherent technical or sejentific merit. Grant applications must clearly define and document, where possible: (a) the energy advantages; (b) the novelty as well as realization potential, and (c) a favorable outlook for economio benefit by the year 2000 . The grant application must be based on normally-accepted laws of nature or sound engineering principles.

b. Deaigning Novel Nanogcale Electronics Capability-Grant applications for novel research are sought on advances in electronic signal processing, based on electronic properties of nanoscale size electronic materia]s, such as clusters, quantum dots, or single molecules. The objective is to develop new approaches for electronic switches, connections, transmission pathways, and other signal processing aspects for further miniaturization of electronics beyond the current mierochip scale. Approaches of interest include application of new knowledge in nanocrystelline solids; monolayer films (e.g., selfassembled monolayers); and organic, orgenometaltic, molecular, and bio-based processes for designing electronic signal processing elements or components.

Grant applications are sought to discover and develop molecule-based electronic mechanisms for efficiently processing ultra-low energy signals on a dimensional scale in which the bulk material properties, on which semiconductor technology is based, are no longer valid. Grant epplications are elso invited to create new electronics technology, using scientific advances in the following areas: electronic polymers, biosensors, quentum dots, fabrication of nonostructures, nanometer molecular lithography, and ultrathto filus. Also of interest is the design of new signal processing devices that assemble elemental nanoscale electronic processes. One issue in this subject area is the need to develop mechanisms to interconnect possible new molecular switches or other nanoseale electronic discoveries. Hence, hybrid technologies that integrate such novel electronic device materials with more traditional electronic systerns are also sought.
Hinfaturization of tradftional semiconductor technology and computer modeling are excluded from this subtople. The novelty must be in the generation or application of new electronie materials, components, or mechanisms, at nanoseale or molecular dimensions, for the ultimate purpose of designing new communications and signal processing. The results at the end of Phase II should indicate a novel molecular or nanoscale electronic signal processing mechanism. Grant applications submitted to this subtopic must present a novel idea for an slectronic component or a novel method of integrating newly-developed components into a larger circuit system. Projecte are not expected to yield a marketable product in the near term. However, a reasonable plan for developing a marketable product or other follow-on funding should be included in the Phase II graut application.

\section{Bíbliography}

1. Carter, F. L., et al, edb., Molecular Electronic Devloes Proctedings of the 3rd International Symposium on Molecular Btectronic Devices, Arlingtom, VA, Octaber 6. 8, 1986, New York: Elseviar Sejence Publighers, 1988 (ISPN 0-444-70547-3).*

2. Horton, L. L., ed., Innovation in Materials Processing and Monufacture: Explaritory Concepts for Energy Applications, Dak Ridge, TN, March 11-12, 1983, Oak Ridge National Laboratory, 1993 (NTIS Ordar No. DE93017674).**

3. O'Neil, M. P., et al, "Picosacend Optical Switehing Besed on Biphotonic Excitation of an Electron DonorAcceptor.Donor Molecule," Scienes 257(506B):63-66, July 3, 1993 (IESN 0036-8075).

4. Waildeak, D. H. and D. N. Beratran, "Molectujer Electronica - Oberrvation of Molecular Reetiffeation," Scionce, 261(5121) $576-577$, July 30, 1993 (IBSN 00968075).

6. "Advanced Energy Projecto FY 1994 Research Suminaries," U.S. Dopartment of Enargy, Eeptember 1994, Report No. DOERR-0617.***

\footnotetext{
* Avaflable from Elagvier Science Publishing Co, Inc. P.O. Box B82, Madizon Square, New Yok, NY 10159

** See Section 7.1

ww Avalable from U.S. Department of Energy, Diviaion of Advanced Enersy Projecta, BR-16, Wabhington, D.C. $20 \$ 95$
} 


\section{ADVANCED INSTRUMENTATION TO EXPLOIT NEUTRON AND PHOTON SOURCES}

DOE supports a number of large-sule user facilitios that provide intense beams of neutrons or photons. Almost every experiment could use a greater flux of neutrons or photons to arry out experiments more quickly and with greater resolution in energy or momentum in order to make measurements more precisely. The development of improved instrumentation, sach as monochromators, high heat load mirrors, microfocussing optics, more efficient $x$-ray and neutron detectors, and beam guide tubes, will multiply the effective strength of every source in a most costeffective manner. Grant applleations are invited only in the following subtoples:

a. High Heat Load Optlcal Elements-Grant applications are sought for the development of mitrors to focus and crystals to monochromatize the very intense $x \cdot r a y$ beams, generated by new synchrotron sources, that can maintain their shape (focus) under conditions of extreme power loads of up to 150 watts per mm $^{3}$. These x-ray begms are very small (approximately $0.2 \mathrm{~mm}^{2}$ ) and have an extremely high energy density. The following should be considered: the reflectivity and thermal conductivity of the surface materia) (a g.t silicon carbide, silicon crystals, jsotopically pure diamond, or multilayers), the means of cooling the mirror or crystal surface (e.e., liquid gallium or ltquid nitrogen), whether to use laminar flow or turbulent flow in cooling, and the geometry of the optical systems. Other factors to consider are the mechanical and thermal stability: vibrations and thermal gradients should be minimized.

b. Mlerofocussing Opties for Nentrons and X-Rays-Grant applications are sought for the development of improved microf feussing optics for both neutron and x-ray bearns. Recent experiments have shown that it is possible to increase substantially the focussing of neutron and $x$-ray beams using tapered class tubes so that the beam of netutyons or $x$-rays does not exceed the critical angle. This has been done with glass pipettes drawn out under hegt to create a very narrow apertare that can be directed at an experimental sample. Such devices would be extremely useful in the analysis of very small parts of a sample which could be scanned across the begrn. For other applications, there is a need to make these tapered glass tubes in a reproducible way so that when severat of them are bundled together, there is a uniform output from ench tube. This is especially important in imaging. There is also the possibility of using $\mathrm{Ni}^{\mathrm{sg}}$ on the interior of such glass tubes for nentron microfocessing applications.

c. High Count Rate Detectors-Grant applicatons are sought for the development of improved highefficiency neutron and $x$-ray detectors and of the electronic components that process the raw signals. It is very cost-effective to inerease the rate at which data can be abtained through the development of detectors that are more eficient. The limiting factors in handling such large wount rates often appear to he in the electronics that processes the raw signals. Improvements in the state-of-the-art in this area might include, for example: parallel processing of detector signals, even to the extent of each pixel in a two dimensional detector having its own memory; materials which respond to neutrons or tr-tays with an improved fast recovery; and two-dimensional detectors with increased spatial resolution.

\section{Bibliography}

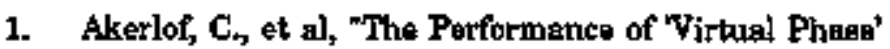
CCDe as Detectors of Minimum-Ionizing Particles", Nucleer Instruments and Mothoda in Physics Rasonarch. VAS200N1(B0-100), October 1, 1987 (ISSN 01168-9002).

2. Fround, A.K. and D. M. Mille, "Summary of Satellito Workshop on Thermal Problems of Synchrotron Radistion Optäes," Review of Seientific Inotruments, V68:N1Pt.11B(1628-1624), January 1992 (ISSN 00846748).

8. Gruner, Sol M., "Time-Reeolved X-Ray Diffraction of Biological Materials," Science, V238:N4825(305-312) (ISSN 0086-8075).

4. Hynecek, J., "Vrrual Phase Technology: A New Approach to Fabrication of Large Area CCD (Imager Applications)," IFEE Trapgactigng on. Electron Devicen, Va8:No(4a8-489), May 1991 (ISSN 0018-9883)**

5. Lander, G. H. and V. J. Entery, de, Seientific Opportunities with Aduanced Facitities for Neutron Scattering Workehop, Sheller Island, NY, October 23. 2984, 170-186, CONF-641026 (NIIS Order Na, DE85012123).**

6. Marrander, A. T., at al, "High Heat Load Performance of an Inclined-Crystel Monochromator with Liquid Galliom Cooling on the CHESS-ANL Undulator," Nuclear Instruments and Methode in Fhysics Reeearch, (Bection A-Accelerators, Spectrometore, Dotectors and

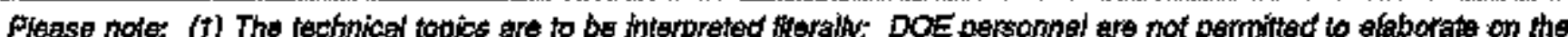

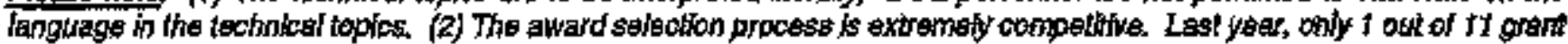

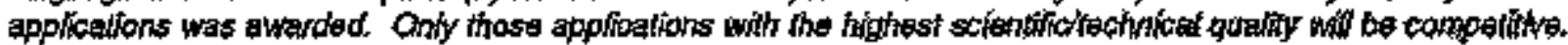

\footnotetext{
-
} 
Aesociated Equipment) Seventh Nationt Conference on Synchrotron Radiation Instrumentation, Baton Rouge, LA, October 28-31, 199I, VA819:N1-\$(188-196) (ISSN $0168-9002)$.

7. McBre, M. R., at al, ed., Proceodings of the Oak Ridge National Labaratory/Brookhaten Nitional Lahoratory Workshop on Neutron Scattering Instrumentation at High Flux Reactors, Oak Ridge, TN, Jtine 5-7, 1989, CONF-8906811 (NTIS Order No. DE9100100\$), **

8. MeGrath, R. D., "Radiation Effects in a Virtual Phase CCD Imeger," EEE Trankactions on Nuclear Bcience, V28:N614028-4032), December 1981, (ISSN 0018-9499).

9. 'Neutron Sources for Americe's Future: Report of the Basic Energy Sciencer Advisoly Committes Panel on Neutron Sources,- January, 1983, Report No. DOEER0576P (NTIS O)der $\mathrm{No}_{0}$ DE9900798B)..**

\footnotetext{
* Available from IEEE Service Center, 445 Hoes Lane, Pisçateway, NJ 08854 (Telephone 800-678-4933)

** See Section 7.1
}

\section{CERAMIC FIBERS AND FIBER COATINGS FOR HIGH TEMPERATURE APPLICATIONS}

This topic provides small businesses with an opportunity to carry out substantially novel resesrch in synthesis and processing of fỉbers for advanced ceramic composites. Fiber reinforced ceramic matrix composite materials offer desirable properties for high temperature environments including high strength, corrosion resistance, and low density. Their use in engine components such as heat exchangers, combustion liners, turbine tip shrouds, and other structural elements could potentially lead to reduced energy usage and cost, and lower nitrogen oxide and carbon dioxide emissions. Limitations in the current technology include high cost, thermal instability, and fabrication complexity of the fibers used as reinforcing agents. A grant appitication should be submitted for consideration under this topic only if the research represents significant advances in materials or in processing that will lead ultimately to higher quality fibers than those currently available. Grant applications limited to a simple incremental improvement will be declined. Grant applications for a study that would yield results limited to a single commercial material will be declined. Grant applications are invited only in the following subtopies: a. Fiber Synthesis and Processing-Grant applications are invited on new synthesis and processing schemes for the production of oxide or siticon carbide ceramic fibers for advenced continuous ceramic matrix composites that will have the properties of high strength, thermal stabl]ity, oxidation resistance, and creep resistance. Especially needed are fabrication routes that would lead to reduced cost (less than $\$ 200 \mathrm{Jb}$ ) and would deliver reproducible and reliable fiber products in quantities suitable for new applications.

b. Fiber Costing Development-Grant applications are invited on new synthesis and processing sthemes for fiber coatings that will provide good debonding behavior and low sliding resistance to the fiber in a ceramic matrix composite. The coating should also prevent strentsth degradation of the fiber. The issues of fiber reliability, reproducibility, and costaffectiveness are germane to the development of processing routes, and must be discussed in the grant application.

\section{Blblfography}

1. Becher, P. F., et al, ed., Aduanced Structural Ceramics, Symposilum, Boston, MA, December 1-3, 1986, Matoriala Research Socjety, Pitteburgh, PA, 1987 V78 (ISBN $093185743 X$.

2. Davis, J. B., et al, "Fiber Coating Concepts for BrittloMatrix Compogites," Journal of the Arnerican Coramic Bociety, V76:N5(1249-1257), 1993 (IS8N 0002-7020).

3. Mazdiyaeni, K B., ed, "Fiber Reinforcod Ceremic Composites: Materiale, Proceseing, and Technology," Park Ridge, NJ, Noyes Publications, Materiale Seience and Process Technology Series, 1900.

4. Rhine, W. E, et al, ed, Synthesis and Processing of Ceramics: Scientific Issues, Symposium held December 2-6, 1991, Boston, MA, Materials Research Society, Pittsburtigh, PA, 1992 (ISBN 1558991438).

5. Sacks, Miche] D., ed., -Advanced Compoeite Materiala: Processing, Microstructures, Bulk, and Interfacial Properties, Characterization Methode, and Applicatione," Symposium on Composites: Processing, Microstructure, and Properties, V19, The Amertcan Ceramic Society, 1991 (ISBN 0944904\$94). 


\section{CHEMICAL SCIENCES RESEARCH}

Research in the chernical sciences can contribute to the advancement of virtually all sectors of the economy through new developments important to arees of energy generation, conversion, and storage, and to environmental remediation and waste minimization. This topic singles out and is limited to four specific subtopies in this broad field: analyticel sensors, membrane separations, catelytic conversions, and advanced battery research and development. Before oubmitting a grant applfeation to this topic, applicants should consider other technical topic descriptions, such as those under topic number 1, Novel Materials for Sustainable Energy Development; and topic number 28, Charactert. zation, Honitoring, and Sensor Technologies for Radloactive and Faztardous Waste, to assure that the application is submitted to the most appropriate techntcal topic. Crant applications are Invited only in the following subtopleg:

a. Advanced Sensors for Analytical Chemleal Heagurements-Determination of chemical composition is being done jncreasingly on the, in real time, without removal of samples of a material for aubsequent, analysis. The components of interest may be unstable, or immediate feedback on changes in composition may be required to keep manufacturing or waste streams under control. Progress has been made in developing a variety of optsteal and electrochemical sensing devices for analytical purposes. However, these allow measurement of only a small number of chemical species and often are limited to a restricted range of operating conditions. In the context of this subtopic, a sensor is defined as a miniature, insitu probe which, by ftself, indicates the presence and/or concentration of one or more chemical mpecies. Specifically, it does not include an offline epectroscopic device which, by itself, is ueed to indicate the presence of the chemical specied. Additionally, fiber-optic materials by themelves are not considered sensors and thus are excluded.

Grant applications are sought on advanced sensors that will provide one or more of the following capabilities: highly localized sensing (micron-size scale, if possible), operation in extreme temperature and/or pressure environments, and rapid response. In all of the above cases, the interest is in the sensiog or analysis of chemical species. While such devices will undoubtedly have applications in energy technologies, the proposed research should not be targeted to a specific application, but should seek understanding of princjples of operation and the broadest possible range of operating capabilities. The interest is in novel types of sensors, and not in research leading to incremental improvements in existing devices.

b. New Materials for Enhanced Selectivity and Efficiency in Hembrane Separations-Membranes currently in use incorporate a variety of suhstances for separation of raw materials or waste streams into their chemical components. Grant applications are sought on substances that emplay novel concepts for obtaining greater selectivity and/or higher fluxes than can presently be achieved for the isolation of valuable components from complex mixtures. This subtopic is limited to new chemical compositions and/or new macro- or micro-structures for membranes. Plans for testing the new materials for selectivity and efflciency should be incorporated ints the grant application. Grant applications should not emphasize a spectific separation, but should describe fundamental research into the relationship between the novel chemical or physicgl structures and their separation properties, leading to potential applications in the separations field, possibly in Phases II or III.

c. Catalytic Reduction of Nitrogen Oxiden under Oxidizing Conditiong-While catalysts have contributed substantially to the reduction of pollutants from antomobsile exhaust, existing catalyst technology will not meet future environmental requirements. A persistent problem in the use of the intemal combustion engine is the formation of nitrogen oxides froms nitxogen in the air. Catalytic reduction for the removal of oxides of nitrogen, as opposed to redesign of the engine to prevent their formation, is a desirabla stratesy.

Grant applications are sought for the characterization of heterogeneous redox catalytic processes at tompera. tures relevant to the problem of nitrocen oxide emissions from interral combustion engines. Applications should clearly demonstrate the feasibility and means of achieving $\mathrm{NO}_{x}$ reduction and should result in an improved understanding of the relationship between the adsorbate reactions and any oxidgtion and reduction reactions of the surface.

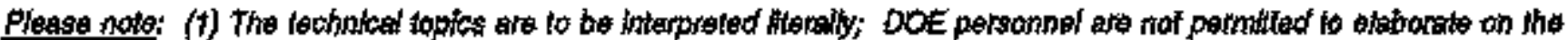


d. Advanced Battery Researeh and Development-Batteries are a mainstay of contemporary electronic and information industries. The performance of batteries is often the limiting factor that hinders the development of improved portable devices such as cellular telephones, laptop computers, handheld tools, and other eonsumer products. Stringent environmental requirements impose restrictions on the use of battery materials and components deemed to be harmful to the ervironment or human well-being.

Grant applications are invited for research related to the development of new or significantly improved battery technology for a wide range of applications, with particular emphasis on improvement in battery size, weight, life, and recharge cycles for nonautomotive applications. Batteries for transportation and fuel cells are specifically excluded from consideration. Appropriate topios for research include: electrode research including investigations of graphitized and composite electrodes for lithium ion cells, metal hydrides, bifunctional air electrodes, composite electrode structures, failure and degradation of active electrode materials, and thin-film electrodes. Electrolyte studies could include ionje conducting polymers and room temperature molten salt. Consideration will atso be given to research on the problems of overcharge/overdischarge, power eapability , and cyclability of anoiles in hithium ceils, oxidative degradation of electrolytes by high voltage eathodes, and highly conductive thin-film ceramic electrodes. Appropriate topics in the ares of characterization and methodologies include problems of electrode morphology, corrosion, separator/electsolyte stability, and stable microslectrodes. Other topics of interest include novel battery systems, separators, and transport properties of electrade and electrolyte materials. The intersist is in novel research and technology development, and not in research leading to increntental improvements in existing devices.

\section{Bibliography}

1. Baker, R. W, et al, Membrane Separation Systems - A Research and Development Needs Assessment,- U.S. Department of Energy, Office of Energy Regearch. Washíngton, D.C., Report Nog. DOE/ER/30133-H1-Vol.1 and DOEFR30133-H1-Vol.2 March 1991 and April I991 (NTIS Vol. 1, DE90011770, Vol. 2, DE90011771).*

2. Bravo, J. $\mathrm{L}_{\mathrm{r}}$, et al, Assesoment of Potential Energy Savings in Filsid Separation Teahnologies: Technalogy Review and Recommended Researet Areast Final
Report, U. S. Department of Energy, Waghington, D.C.. Report No. DOE/1D/12473-1, Deceriber 31, 1904 (NTIS DE85018s99/XAB),"

3. Parrauta, R. J., et al, "Enviranmentel Catalyoto," Chemical and Enpinering News 70(36):34-38, 40, 42. 44, September 7, 1992 (ISSN 0006-2\$47).

4. Gardiner. K. W. "Autoutation: Instrumentation lor Process Monitoring," Theatise on Ancilytical Chemistry, 2nd ed., P. J. Elving, ed. (pt. 1, Theory and Practice): 487-540, New York: John Wiley and Bone, Inc., 1984. Vol. 4, Section E, Principles of Instrumentation for Analysis (ISBN 0-47101- -336 ).

5. Hirschifeld, T., "Inetrumentation in the Next Decade," Bcience, 230(4723): 286-81, Oetober 18, 1985 (ISSN 0036-8075).

6. Lloyd, D. R, ed., Materials Science of Synthetio Membranes, ACS Symposium Series No. 269, Washington, D.C.: American Chemical Society, 1984 (IBBN 0-8412-0887-5).

7. McLarnon, F. R. and E. J. Cairns, "Energy Storage," Anmual Review of Energy, 14:241-272, 1969 (ISSN 08921626).

8. Seiyama, T., et al, ede., Procesdings of the International Meeting on Chemical Sensorg, Fukuobz, Japan, Septembar 19-22, 1983, Analytical Bympoeis Beriob, Vol. 17, New York: Elgevier Science Publibhing Co, Inc, 1984 (ISBN 0-444-99638-9) (Publisher Order No. I895$83)_{*}^{* * *}$

9. Truex, T. J., et all, "Catalysta for Nittragen Oxidue Control Under Lean Burn Conditions," Flatínum Metals Review, 86(1):2, Jenuary 1992 (ISSN 0082-1400).

10. U.S. Department of Energy, "Workshop on Advanced Battery Technology Research and Development," Ontice of Basic Energy Sciences, Chemical Seiences Divieion, Weahington, D.C., June, 1992.****

\footnotetext{
* See Section 7.1

* Avallable from the American Chemical Soctety, 1165 16th Stroot N.W, Washington, D.C. 20086

*r* Avallable from Elsevier Sxience Publishing Co., inc. P.O. Box 882, Madiaon Squere, New York, NY 10159

*** Available from the US. Department of Energy, Orges of Basic Enerey Bciences, Chemical Sciences Division, ER-14, Washington, D.C. 20596
} 
5. INFORMATION

INFRASTRUCTURE

FOR THE NATIONAL

INFORMATION INITIATIVE

Historically, communication and eomputing technology. j.e., leading edge information technology, has been a powerful instrument of change in our society. The civilian National Information Infrastructure (NII) program will help transform the Department of Energy and present $\mathrm{a}$ new and more open $\mathrm{DOE}$ interface to the public. It will create new collaborative environments by integrating the Department's diverse components, academia, and industrial partners. It can also provide new and innovative capabilities for performing the Department's technieal missions. Through the development of information infrastructure, DOE will transform itself, especially with respect to its ability to operate in an open, collaborative, and efficient fashion, by uging leading edge digital communication and computation to serve the public interest and accomplish its missions. For the development of this new information infrastructure, grant applications axe invited only in the following subtopics:

a. Wide Area Network (WAN) Based Hierarchical, Distributed Database and Data Storage Technologles and Techniques-The advances in hish performance computing and communiteations, combined with the enhanced sophistication of both Grand and National Challenge applications, have accelergted the need for distributed, fast, interoperable, and scaleable technotegies and techniques for storing, manjpulating, and querying large data sets. Grant applications are sought for the development and inplementation of tochnologies and techniques for managing large datasets using WAN based storage and database tools and protocols. Applicants are expected to demonstrate familiarity with the current state of the art in these areas.

b. Wide Area Network (WAN) Based Collaboration Technology and Applieation DevelopmentThe need to efficiently share information and unique facilities remotely, in addition to the growing requirement for telepresence and telecommuting capabilities, demands enhanced collaborative technologios and techniques suck as packetized video/audio streams and nultimedia conferencing, shared whiteboards, and concurrent edjting/uarkup cepebilities.
Grant applications are sought for the development and implementation of WAN based technologies and techniques for providing real-time and interactive voice, vide0, and data exchenge across the Internet and other large distributed, heterogeneous networks. Applicants are expected to demonstrate familierity with the current state of the art in these areas.

c. Wide Area Network (WAN) Authentioation and Security-The srowth of networking, as evidenced by the increased useage of the Internet and the attention devoted to the NI, will continue at its current rapid pace. The components of large, interconnected networks (local networks, hosts, computers, information, data, applications and users) all require some level of security. As the number of individuals, businesses, schools, and other entities using networks grows, so does the need for more sophisticated authentication and security tools. Grant applications are sought for the development and implementation of WAN based security tools, systems, metrics, and protocols in the areas of application and user interfaces, information search and retrieval, and data storage and transmission that can operate across the Internet and other large distributed, heterogengous networks. Applicants are expected to demonstrate familiarity with the current state of the art, in these areas.

d. Wide Area and Distributed Network Based Technologies to Support Enersy Demand and Supply Management-The electric and power utijlities are using and deploying telecommunications to support their principal business of managing and providing energy to their customers. However, the evolving nature of the corporate utility business defmands the development of novel distributed network technologies to enhance the existing capabilities of utilities in the area of real-time energy demand and supply management. The technologies and infrastructures that support energy utility consumers and providers may be leveraged to accommodate other utilities and service providers. Grant applications are sought for the development and implementation of both wide area based and distributed network tools and protocols that enable enerry utilities to jmprove efficiency, conservation, billing, and customer service. Applicants are expected to demonstrete familiarity with the current state of the art in these areas, especially with regard to how the consumer interfaces and connects to both the utility and the NII.

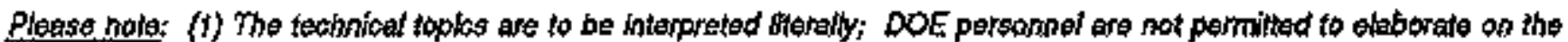

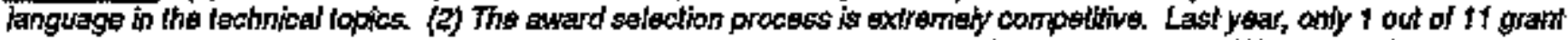
applications was awarded. Only those epplications with the highesk selentifictochnioal qually wis be compoiltive. 


\section{Bibliography}

1. "FY 1995 High Performance Computing and Communications Implementation Plan," National Library of Medicine, April 1994.*

2. High Performance Computing and Communications: Technology for the National Information Infrastructuret Supplement to the President's Fiecal Year 1995 Budget," National Science and Technoloby Council, 1994."**

3. "Realizing the Information Future," National Researeh Council, Computer Science and Teleconamunications Board, 1894.**

4. Vernon, Mary $K$, et al, eda, "RaD for the NII: Technical Challenges," Interunivereity Communications Countil, Inc. (EDUCOM), 1994.*****

5. A Vizion for Government Information Technology Services and the Nationel Information Infrastractures: Implomenting the National Performance Review's Information Technology Recommendations, "Govermment Information Technology Services (GITS) Working Group of the Information Infrastrueture Task Force Cammitteo on Applications and Technolegy, September 1994. $\dagger$

\footnotetext{
* Ayaileble frotn the National Library of Medicine, National Coordination Oflice for High Performance Computing and Commumicatione, 8600 Rockville Pike, Bethesda, MD 20894

* Available fropn the Office of Science and Technology Policy, Executive Office of the President, 2100 Pennaylvania Avenue, NW, Wakhington, D.C. 20500

mu* Available from Computer Stience and Telecommunicetona Board, National Acaderny of Sciences Press, 2101 Congtitution Avenut, NW, Waghington, D.C. 20418

**** Available from EDUCOM, ATTN: NII-Forum, 1112 16th Street, NW, Suite 800, Washington, DC 20096

$\dagger \quad$ AYailable from U.S. Department of the Treasury, Offite of Telecommunicatione Management, 1425 New York Avenue, NW, Suite 2150, Wsehington, D.C. 20220
}

\section{HIGH TEMPERATURE SUPERCONDUCTIVITY FOR ENERGY APPLICATIONS}

High temperature superconductivity (HTS) for energy applications is classed as a critical technology by the 1991 National Critical Technologies Panel. In addition, the Energy Policy Act of 1992 has assigned DOE the responsibility for the development of HTS electric power equipment technologies. Research and developuent on this topic therefore supports national and DOE goals.
HrS was discovered recently, in the late $1980 \mathrm{~s}$, and major berriers stall remain to its practical use. For example, while HTS wires are now available that satisfy basic applicetion performance needs, costg must be lowered and performance raised before use becomes widesptead. For example, HTS wires mugt be econonitally manufactared in kilomater lengths, with the ability to carry large currents in magnetic fields greater than 2 Tesla. This would allow the manufecture of useful components such as motor coils and transmission cables. These components can then enable a new era of advanced electric power equipment. that can lower the cost and pollution associated with electricity generation, delivery, and use.

A world-wide market of several billion dollars per year for superconductivity products has been predicted for the year 2000 , with wire-using products comprising the largest market share. Continued innovation is needed to overcome the existing technical and econotnic barriers to exploiting this tremendous commercial potential. Incremental advances to current HTS technology will not be considered. Grant applice. tions are invited only in the following gubtopics:

a. IISS Wire and Coil Manufacture--Grant applications are sought for the development of innovative processes and process quality management technologies for manufacturing FTS wires that will (1) lead to manufactaring costs comparable to that of low temperature superconducting wire (presently around $\$ 90 / k A m p-m e t e r$ for $\mathrm{Nb}_{g} \mathrm{Sn}$ composite conductors), or (2) improve HTS wire performance in areas such as: uniformity of long wires, current carrying ability (above $100 \mathrm{~A} / \mathrm{sq} \mathrm{mm}$ ), operating temperature ability, operating magnetic field ability, flexibility, and durability. Grant applicatonons are also sought for the development of innovative HTS coil manufacturing processes and process guality management technologies that will lower costs or improve HTS coil performance in aress such gs: durability, operating magnetic field ability, and efficient alternating current operation.

b. HTS Electrical Device Development-Grant applications are sought for development of HTS electrical devices, with presently achievable HTS performance, that cen improve the efficiency and economits of electrical generation, delivery, or use. These may be innovative designs for familiar electrical devices such as generators and motors, or proposed new inventions which are enabled by HTS. Grant 
applications for device-associated coil protection mensures are also sought.

\section{Bibliography}

1. Dirks, A. A, ot al, "High-Temperature Stperconducting Traneformer Performance, Cast, and Market Evaluatian," "September 1998, Repert No. PNL-7318/UC221, (NTIS Order No. DE94005494/XAB)**

2. "Energy Applications of High-Temperature Suporconductors," Flactric Power Research Institute, Palo Aito, CA, July 1992 (EPRI Ordor $\mathrm{Na}$. TR-101695)**

8. Farges, Jean-Pierre, ed., "Thallium-Baged High- $\mathbf{T}_{c}$ Superconducting Oxides-A Summary," Organic Conductors: Fundamentals and Applications, Applied Phyics, Vol, 4, 1994 (ISBN 0-8247-9216-5).

4. Hickn, S. C. and L. T. Newman, etds., "Electric Energy Systome: Supwreonduntivity Applications, " U.S. Department of Energy, Report No. DOEJESS 94/2(PB94938502), March-April 1994 (ISSN 1073-855X).

5. Hall, J. R., "Hieh-Temperatere Spperconducting Current Leads," Proceedings of the 1992 Applied Superconductivity Confenence, Chicaso, IL, Atgust 23-28, 1992, IEAEE Trapkactiong on Applied Saperconductivity V8:N1:Pt.72(B69-875), March 1998 (ISSiN 1051-822a).

6. Kitanura, T., et al, "Design and Fabrication of Bi-Based Superconducting Coil," Praceedings of the 1992 Applied Superconductlutsy Conferances, Chioxgo, IL, Aughuse 23-28, 1992, IFEe Trandactions on Applied Smperconductivity V3:N1:Pt,3(939-941) Warch 1963 (ISSN 1051-8228).

7. Larbalestier, D., "Crittcal Curronts and Magnet Applitcations of High-T, Superconductors," Physics Thday, V44(74-B1), June 1991 (ISSN 0081-9228).

8. Lerbalektier, D. C. and M. P. Maley, "Conductors from Superconductore: Conventional Low-Temperature and New High-Temperature Supercondueting Conductors," MRS Bulletin, V18:N8(60-56), August 1993 (ISSN 08837894).

9. Malozemoff, A. P., "Advanced Technology/Electromegnetigm-\$uperconducting Wire Cote Hotter," IEEE Spectrum V80:N12(26-80), December 1998 (ISSN 001E. 92956).

10. Mchichael, C. K., et al, Practical Adaptation in Bulk Superconducting Magnetic Beating Applications," Applied Phratcs Letkers V60:N15(1898-1895), April 1S, 1992 (135s 0003-6951).

11. "National Critical Technologlea Pantel Raport," National Critical Technologies Panei, March 1992 (NTIS Order Na. PB91-156869/XA1).*

12. Ries, G., "Magnet Tectunology and Conductor Design with High Temperature Supercondnctors," Cryogenjes, VaS:Ne(609-614), 1993 (ISSN 0011-2275).
13. Tixador, $P$., et al, "Supercanducting Permanent Magnet Motor Design and Firat Teats," Proceedings of the 1992 Applied Supercondzetiuity Confenence, Chicago, $I$, Autgust 28-28, 1992, IFGE Trangactions on Applisd Superconductivity, V3:N1:Pt.2(881-884), March 1993 (ISSN 1051-8223).

14. Verhaege, T., et al, "Experimental $7.2 \mathrm{kV}_{\mathrm{mos}} / 1 \mathrm{kA} / \mathrm{sms}$ $\mathrm{kA}_{\text {peok }}$ Corront Limiter System," Proceedings of the 1902 Applied Superconductivity Conference, Chieago, IL, August 23-28, 1992, IFEF Transactions on Applied Superconductivity, Va:N1:P2(574577), March 1998 (ISSN 1051-8228).

16. Yarn, Philip, "Trends in Superconductivity-Current Events," Scientific Anerien V269:14(2), November 1993 (ISSN 0036-8733).

\section{* See Section 7.1 (Telephone 415-855-2411) \\ 7. IMPROVED MATERIALS FOR THE PULP AND PAPER INDUSTRY}

** Available from Electric Power Research Institute (EPRI) Order Services, P.O. Box 50490, Palo Alto, CA 94308

DOE is supporting research on materials technologies that can have significant impact on increasing energy effieiency, productivity, and environmental compliance in the pulp and paper industry. In pulp and paper processes, nearly every form of wear may be encountered, inctuding abrasive and erosive wear, wear by slumies, cavitation wear (in pumps), sliding wear. and impact wear. Corrosion issues are also encountered in the processing of wood fiber to make pulp end pulp to make paper, and in the management of wasta streams at the source. Corrosion problems will probably increase as facilities move towerd the "closed mill" cycle concept.

The focus of this topic is the developtnent of improved or new materials applicable to the unit operation processes involving pulping and bleaching, papermaking, and chemical recovery. Consideration will be given to suitability for potential applications, including improved materials properties and performance, cost-effectiveness, and the ability to manufacture parts of requisite sizes and shapes. Grant applicatious are invited only in the following spbtopiost

Please nots: (1) The technical topits are to be interpreted iffenally; DOE parsonoal ane not permitted fo elaborate on the

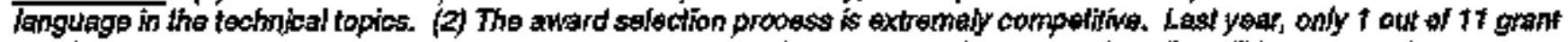

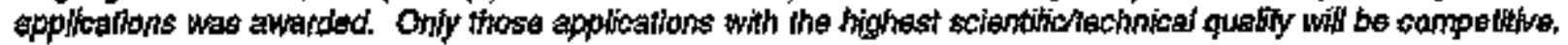


a. Materials for Inproved Pulping and Bleaching-The objective of the pulping process is to separate cellulose fibers from the other components of wond. The processes include methanical grinding, mechanical refiner pulping, thermomechanical pulping, and chemical pulping. Improved meterials needs vary with the type of pulping addressed. Mechanical or refiner pulping includes wear from abrasion and erosion of components, whereas chemical pulping can result in exposure of materials to corrosive and erosive wear from solutions/g]urries. For mechanical grinding, wear resistance is the main property in need of improvement. Grant applications are solicited for materials with at least $50 \%$ increased wesr resistance for use as the rotating grindstones used to reduce the size of logs for further processing.

For mecharical refiner pulping, pulp quality and process efficiency are affected by cortosion associated primarily with presteaming, by condensates containing sulfur-bearing atids and chlorides, and by wear of refiner plates. Rounding of refiner plate bar edges results in lessening the refining capability of the system. Pitting of the bars by cavitation erosion infuences a materials response in refiners. Dashing of plates, which occasionally come in contact doe to minimal clearances, is also a significant issue. Grant appitications are solicited for lighter, stronger refiner materials suitable for high speed operation, and for surface treatment or new materiais to improve wear resistance, cavitation resistance, and toughness of reftner plates.

There are various methods for chemical pulping; the predominant process in the U. S. is the Kraft process, which includes the digestor, the evaporator, and the chemical recovery system. The design of the digester can cause significant changes in materials behavior and requirements. Corrosion and erosion of metallic components, including pipos, valves, and pumps, by sodium/sulfite slurries also occur. Grant applications are solicited for development of materials to minimize caustic stress corrosion in digesters; preferably, development should be coupled with modeling to optimize design operating parameters.

b. Materials for Improved Papermaking-In the papermaking unit process, pulp fibers in suspension are concentrated to the desired level and routed through the papermaking machine to form a dry paper sheet at the dry end of the machine. Materials problems involve corrosion and erosion/abrasion, ss the solution carrying cellulose fibers still containg some chloride or other oxidant. Grant applications are solicited for materials improvements in papermaking machines, spectifically and only for improved metallic alloys for suction rolls and granite rolls, and for improved ceramic coatings for rotls having similar sticking and release characteristics as granite.

c. Materials for Chemical Recovery Syetem8Chemical recovery processes vary with the type of pulping process used. In the Kraft process, a boiler is used to incinerate black liquor while providing steam for cogeneration and plant processes. Black liquor gasification is a new process, whereby the black liquor is pyrolyzed and reacted with stean to form fuel gas and inorganic salts. Valuable fuel gases are formed, and inorganic chemicals are recovered in solid form. Materials problems in chemical recovery systems are primarily related to corrosion, especially in the boiler, where high temperatures are involved and black liquor combustion takes place. It is critical that boiler tube materials not leak any water coolant as water reacts with the molten smelt in the boiler. Grant applications are solicited for materials with improved resistance to oulfidation and/or alkali corrosion/erosion for tubes, including materials and inexpensive coatings for enhancement of operational lifetimes at tenperatures of about $1500^{\circ} \mathrm{F}$.

\section{Bibliography}

1. Colwell J. A, "Ertimation of the Effect of Changing Boiler Operating Parametera on Fireside Corrosion in the Lower Furnace of a Kraft Recorery Boiler, "Final Report for the American Paper Institute (APD), October 1992.*

2. Colwell, J. A, "On the Mechantsm of Corrostion of Composite Tubes at Porte in Kraft Recovery Boilors," Proceedings of the Seuthth International Symposium on Corrosion Pulp and Paper Indtstry, Institute of Papar Science and Technology (IPST), Tappi Press, Orlando, Florida, Nowember 16.20, 1992, N440(231-242), May 1992.**

8. O'Brien, M, "Paper induetry and U.S. Department of Energy (DOE) Labe Address Reeearch Priorities," Conference entilled The Pulp and Paper Mill of the Fufurean Information Exchange, PaperAge V109:N1 (22), November 1993 (ISSN 0081-1081).

4. Sherp, W. B. A. "Overview of Recovery Botler Corrofion," Proceedings of the Seventh International Symposium on Corrosion Putp and Paper Induatry, Institute of Paper Sciance and Tecknology (IPST), Tappi 
Press, Orlando, Flordda, Nowember 16-20, 1992, N440(23-82),***

5. Sobezyneki, S. F., Peper Mill of the Future: [the Year] 2020 tand beyondi", U.S. Department of Energy Workshop, The Pulp and Paper Mill of the Future,

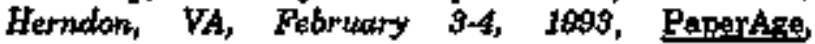
V109:N4(21-22), Apri] 1993 (ISSN 0031-1081).

6. Thompoon $R$, et al, "Corrosion of Generating-Bank Tubes at the Mod Drum Interiace in Kraft Recovery Boilers," Proceedings of the Seventh Intemazional Sympositum on Corrosion Pulp and Paper Industry. Instiftte of Paper Sctence and Technology (IPST), Tappt Prest, Orlando, Forida, November 16-20. 1992, N440(309-318),**

7. Young, I. K. and Fowler, R. A., "Overview of the Government/Induetry Workehop on Opportunities for New Materials in Palp and Paper Procesging," Pacizic Northurest Laboratory Workshop, Partland, OR, August 12-18, 19\%8, DOERL-94-66 (NTIS Order No. DE94013670), ****

* Atrailable from the Arrerican Forast and Paper Assocjation, 260 Madison Avenus, New York, AY 10016

* Araileble from the Inktitute of Paper Sciepce and Technoloty (IPST), 575 14th Strest, N.W., Atlante, GA (Tejephone 404-658-9500)

*** Seo Seetion 7.1

\section{ADVANCED DRILLING TECHNOLOGY}

Drilling technology has evolved during this century into a complex set of processes for breaking and removing rock to provide access to a target region in the subsurface. The United States has been a leader in worldwide drilling technology; however, to remain competitive, it will be necessary to develop new advanted systems to reduce both drilling time and costs. The National Research Council of the Nationai Academy of Sciences (NAS) recently completed a stody of "Advanced Drilling and Excavation Technologies for the Futurs" which identified promising areas for major technical improvements. The NAS study recommends estahlishment of a national research and development program that focusses on a smatt drilling system. This system will be capable of sensing and optimizing drilling operating parameters as wall as evaluating and adapting to formation parameters in order to reach desired targets. Devejopment of a smart drilling system will depend upon major advances in several key elements of the drilling process. Four of these key elements are degcribed below. Research and deve]. optent projects in grent applications should be designed to ultimately lead to drilling hardware that could be incorporated into a smart drilling system. Grant applications are fuvited only in the following subtopics

a. Drill Bit Bensing and Evaluation-Measurements of limited drilling parameters are typically made at the surface during drilling. Current statb-of-the-art downhole technology supports measurement of some drilling parameters at the bit-rock interface. Included are rate of penetegtion, wejeght on bit, torque, and rotation rate. Grant applications are sought to expand these downhole measurements to include either: (1) sensing bit wear in order to warn of impenting failure or other need for replacement, or (2) sensors that measure drilling mud properties at the bit to improve borehole qusisty and mud onditioning. Downhole sensors should be compatible with existing or advanced techniques for trangmitting data to the surface.

b. Formation Properties Senging and Evaluation-Downhole measurement of formation properties during drilling is an active, expanding field. Significant new advances bave been made during the past ten years. Grant epplications are sought for the development of improved capabilities to make measurements around and ehead of the bit. At least one of the following three areas must be addressed: (1) fracture detection away from the bit based on electromagnetic, acoustic, or other innovative methods, (2) advanced formation evaluation based on sensor measurements, or (8) high-resolution imaging capabilities.

c. Drill Bit Postitioning and Bteering-Position and steering systems are commercially available based on gyro, accelerometer, magnetic, and electromagnetic technology. Development of the smart drilling system will reguire advances in current positioning and steering systems. Grant applications are invited for the development of new sensing systems capabie of determining bit position in three-dimensionel space within an acenracy of one foot and/or determining bit direction and the resultant forces to optimize steering.

d. Borehole Stabilization-Stabilization of the borehole while drilling is impertant to prevent loss of drilling fluid or caving of the wellbore wall. Grant applications are invited for new downhole sensing systems that ean determine borehole stability during

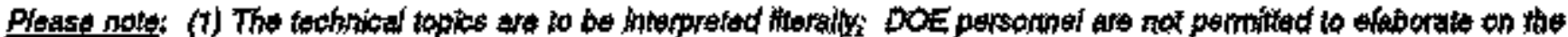

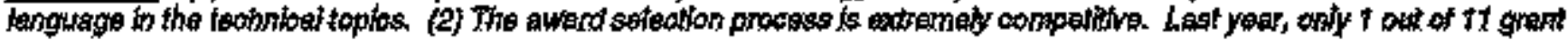

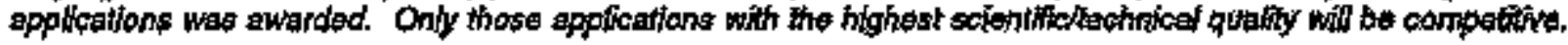


drjlline. Examples of stability-related parameters include measurements of friction between the drill string and the formation, stress state in the wall rock, and loss of drilling fluid near the bit.

\section{Bibliography}

1. Burkman, Jeff and Nic Nickels, "Dírectional, Navigational and Horizontal Drilling Techniques," Geothermal Rasources Council Bulletin V19:N4, pp. 106-112 April 1990 (ISSN 0160-7782).

2. "Drilling and Bxeavation "Technologies for the Future," Nationai Research Coundil, p. 161, Washington, D.C, National Academy Press, I994 (ISBN 0309050766).

3. Honeybume, Will, "Future Measurement-White-Drilling Technolagy Will Foeue on Two Lavels," Oil and Gas Journal, V. 23:9;71.75, March 1985.

4. Miaurer, Williarn $C_{1}$ Advanced Drilling Techniques, Tulsa, OK, Petroleum Publishing Company, p. 698, 1980 (ISBN 0878141170).

5. Maurer, William C., at al, "Deep Drilling Basic Regearch," V1:Final Report, pp. 60, Gas Rezearch Instituts Report, June 1990 (Report No. GRI-6088-2801731).

6. Maurar, William C., "Novel Driling Techniques," International Journal of Rack Mechanicg and_Mining Sctences p. 114, Oxford, Now York, Pergaman Press, 1968 .

7. Millheim, K.K., "Advances in Drilling Technology (1981-1986) and Where Drilling Technology is Heading," Procesdings of the International Meeting on Petroleum Engineritg, Beijing, China, March i7.20, 1986, Soclety of Petroleum Engineers, Richardenn, TX., pp. 493-506 ICONF No. 860844).*

B. Mock, J.E, et a), "The National Advanced Drilling and Excavation Technologies (NADET) Program: A New Collaborative Research and Development Initjatbve," Proceedings of the 1994 IADC / SPE Drilting Conference, February 1994, pp. 693-701, Society of Patroloum Engineert, Report No. PDCOE6.*

9. Murphy, David Patriek, "What's New in MWD and Formation Evaluation," World Oil V214:47-60,52, May 1993 (ISSN 0043-B790).

* Araileble from The Soctety of Petroleum Engineers, Richardaon, TX 27505 (Telephone 214-952-9893)

\section{ADVANCED ENVIRONMENTAL MONITORING TECHNOLOGY}

Characterization of subsurface, atmospheric, and oceanic environments is a key element of several DOE ressearch efforts designed to analyze the transport, fate, and human and ervironmental health effects of energy materials and wastes. This topic concerns innovative technologies to advance environmental monitoring capabilities. Monitoring in this context means longterm measurement of biological and physicochemical properties of natural systems with low-maintenance or eutanomous sensors and equipment. Monitoring will be a critical assessment and control activity in designing for sustsinable development, as well as for future, pollution-free, zero-discharge, environmentally benign energy systems. Subtopics $a$ and b relate specifically to the monitoring and remediation of the subsurface environment, while subtopics $c$ and $d$ concern environmental monitoring in genera].

Grant applications must include bench tests of critical technologies. Critical tichnologies are those components, materials, equipment, or processes that significantly limit current capabilities in the specific subtopic area. Applications that propose only incremental improvements or enhancements to existing technologies will not be considered. Grant applications in all subtopies must describe in the technickl approach or work plan the purpose and benefits of any proposed teaming arrangernents with government laboratories or universities. Applications for all subtopies should provide information supporting claims of commertial potential for proposed technologies (e.g., endorsements from relevant industrial sectors, market analysis, or identification of potential spin-offs). Grant applications are invited only in the following subtopica:

a. Supereritical Fluid Extraction-\$npercritical fivids (SCFs) are fluids that are at a state above the critical temperature and critical pressure of that fluid. Several SCFs have dessirable physicochemical properties at moderate pressures and temperatures that make them well suited for environmental monitoring and remediation applications. Supercritical carbon dioxide $\left(\mathrm{CO}_{2}\right)$, for example, is an environ-toentally beniga solvent that dissolves nonpolar species and can be substituted for solvents in the synthesis of polymers and other organic materials. Addition of small anounts of an entrajner allows polar molecules to dissolve in the supercritical $\mathrm{CO}_{2}$ as well. Therefore, 
supercritical $\mathrm{CO}_{2}$ can be used in a hast of chemical processes, repiacing or reducing the amoumts of organic solvents used. Supercritical fluid extraction (SFE) (the use of supercritical fludds in an extraction process) can be used to remove inorganic and organic compounds and contaminants from subsurface matrices and glso as a solvent substitute in chemical processing of wastes. SFE is being used in epplications ranging from the analysis of phospholipid fatty acids (PLFA) (which are short-lived molecules found only in living cells) to the separation of metal ions from soils and groundwater.

Grant applications are sought in one of the following three areas: (1) Development of extraction methods, processes, materials, ar equipment for removing inorganic or organic compounds from complex subsurface matrices using SFE. Fxamples of critical technologies include, but are not limited to, extractors, recirculation pumps, compressors, and adsorbent beds. (2) Development of components, materials, systems, and sabsystems for field-portable analytjcal instrumentation that uses SFE in conjunction with a suitable detection systern including (but not limited to) spectroscopic and/or chronuetographic detectors. The primary interest is in simple and rapid field-anrvey instrumentation that provides universal detection for a wide rance of pollutants at ppm to ppb sensitivitjes. (3) Development of methods, materials, or equipment that anbstítute supercritical flutids for organic solvents leading to a more environmentally benign process. All technologies proposed for this subtopic must rely primarily on the use of supercritical fluids, reduce the use of organic solvents, be significantly faster than standard extraction methods, and be schievable at moderate pressures and temperatures. Critical technologies proposed for this subtopic must be novel with regard to \$CF, semple handling, or extraction control, and functionally indispensable for an SFE operation. Minor adaptations of readily avallable hardware for use in an SFE system are not responsive to this subtopic.

b. Remediation Analysir - Substurface remediation tochnologies have expanded steadily and improved over the last decade. Soil washing, solvent extraction, bioremediation, vapor extraction, chemical treatiment, and forms of thermal treatment have grown by 44 percent at Suparfund sites sinee 1982, However, the effectiveness of these technologias often cannot be assessed in a timely manner because of inadequate site analysis prior to remediation, lack of sensing and process-control technifques, and difficulty in obtaining uncompromised samples from remediation sites, especially subsurface ones. Grant applieations are sought to develop: (1) Innovative methods, processes, materials, andor equipment for assessing the efficacy of remediation actions. The proposed tachnologies should indicate the effectiveness of remedial activities in relation to natural recovery processes occurring at untreated sites with comparable environmental insults.

(2) Process control systems, materials, components, or equipment that will improve temediation effectiveness. The proposed tochnologies must significantly reduce remediation duration and/or costs through advancements in the methodologies used to monitor, analyze, or control the remediation process. (8) Novel methods, field-data display techniques, three-dimensional imag. ing equipment, and softwere, to precisely determine, display, and/or track operations to allow dismimination between elosely spsced but eeologically dissimitar samples.

Techniques proposed for this subtopic should not require regulatory epproval for implementation. Minor adaptations of readily available materials or hardware for such use not responsive to this subtopic.

c. Biosensors and Genetic Probes-There is a need for sensitive, accurate, and real-time monitoring of bjological organisms and processes and physicochemical parameters in the environment. Uses for such environmental measurement capabilities range from bioremediation of subsurface hazardous waste sites to waste-water analysis. Many new technologies in biomoleculer and gene probe based assessment have been created in the laboratory; yet, beyond the clinical environment, few bave reached the standardized, instrumented, or sutomated state required for environmental applicetions. Grent applications are sought to develop: (1) Robust but sensitive biosensor devices (devices employing biological molecules or syrstems in the sensing elemente), or eritical technologies for them, that can be used for field-monitoring of environmental processes or parameters. Also of interest are integrated biosensing and controller/signal processing systems for antonomous or unattended mesgurement applications. Sensore and systems proposed must bo able to detect geological, bjological, chemical, or physica] processes that trensport, disperse, and transform energy-related materials in the atmosphere or the terrestrial or marine encosystems. Grent applications should addrass the environmental signifieance of the parameter to be

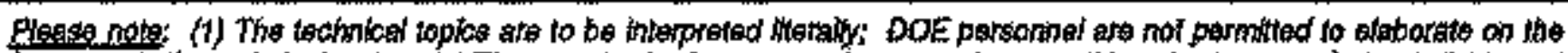

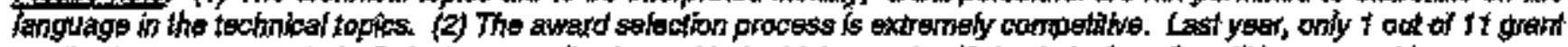

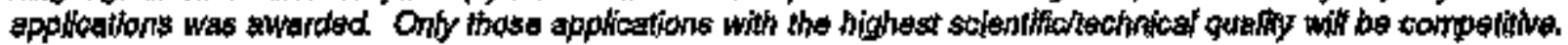


monitored by the biosensing system. Biasensing systems may incorporate (but are not limited to) whole cell biosensors (chemoluminescent or bioluminescent systems), enzyme or immunologicel linked detection systems, membrane lipids, or DNA RNA probe technology with enzyme amplification of target signals. (2) Enhanced sample purification methods/techniques for biomolecules which will minimize the required sample size and permit in-situ detection. Examples of purification processes currantly used are centrifugation, precipitation, and agarose gel electrophoresis, depending on the intended test. (3) New gene probes for speciftc environmental bacterial species. The cloned DNA sequences should be developed with closely loceted markers to prevent separation. In addition, the gene selected for the probe must discriminate between species but not be so specific that minor base pair mutations will cause bacteria to be overlooked. Minor adaptations of readily available materials or hardware for such use are not responsive to this subtopic.

d. Fiber Optic, Solid-State Chemical, and Silicon Sensors-Fiber optic sensors (classified as intensity-based, wavelength-based, or phase-based sensors) offer several advantages over conventional sensors incluzding inkerently high sensitivity, large dynamic range, intrinsic immunity to electromagnetic interference, geometric flexibility, and light weight. Solid-state chernteal sensors and silicon mieromachined sensors also offer several advantages over conventional sensors due to their small size, relatively low cost in production quantities, linearity, and rapid response time. The benefits of small-scale monitoring devices include simpler deployment in remote locations, potential cost. advantages, and enhanced access to the monitoring site. Sensors and systems proposed must be able to detect geological, biological, chemical, or physical procosses that transport, disperse, and transform energy-related materials in the atmosphere or the terrestrial or marine ecosystems.

Grant applications must address the environmental significance of the parameter to be monitored by the proposed sensing devices. Grant applications are sought to develop: (1) robust but sensitive fiber optic, solid-state chemical, or silicon micro-machined sensors, or critical technologies for them, for field-monitoring of environmental processes or parameters (atmospheric, oceanographic, or terrestrial), or (2) integrated sensing and ricroprocessor/signal processing systems for autonomous or unattended measurement applications which utilize fiber optic, soljd-state chemical, or silicon micro-machined sensors (either a single sensor or a seite of sensors). Innovative integration of components such as micro-machined pumps, valves, and mierosensors into a complete sensor package is considered responsive to this subtopic. Minor adaptations of readily available materials or hardware for such use are not. responstve to this subtopic.

\section{Bibliography}

1. Colwell, F. S., et al, "Innovative Techniques for Coliection of Saturated and Unsaturated Basalts and Sediments for Microbiological Characterization," Journal of Microbiological Methode, 15(4):279-292, 1992 (ISSN 0167-7012).

2. Dandridge, A and G. B. Cogde]!, "Fjber Optie Sensore Performance, Reliability, Bmalineas," Sea Technalory Văs:N5(31), May 1994 (ISSN 0098-3661).

a. Findlay, R. H., et al, "Quantitative Determination of Microbjal Activity and Community Nutritional Status in Estuarine Sedimenta; Evidence for a Disturbence

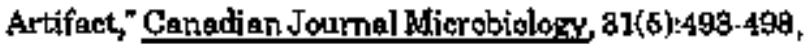
1985 (ISSN 0008 4166 ).

4. Hedrick, D. B, et al, Disturbance, Starvation, and Dvarfeeding Stragess Detected by Mierobial Lipid Biomarkers in High-Solids, High-Yield Methanogenuc Reactors," Joumal of Incusetrial Microbiolory a(2):9199, 1991 (ISSN 0189-4148).

5. MeCurley, M. F. and W. R. Seitz, "Fiberoptic Seneor for Salt Concentration Baped an Polymer Swelling Coupled to Optical Displacennent," Analyticn Chimica Aeta V249:N2(373-980) 1991.

6. Moir, Stephen, "Chemfet Beneore. in Induetrial Procers Control," Seneore, V5:N7(39-44), July 1988 (ISSN 0746. 9464).

7. Phelps, T. H., et al, "Methods for Recovery of Desp Terregtrial Subzurface Sediments for Mierobiologica] Studies", Journal of Microbiolagical Methode, 9(4):267. 279,1989 (ISSN O167-7012).

8. Phelps, T. J., et al, "Utility of Radiotracer Aetivity Meesurements for Subsurface Mimrobiology Studies," Jommal of Miarobiological Methodg 9(1):15-27, 1989 (ISSN 0167-7012).

9. Rivęra H., et al, "A Microensor to Mtasure Nanomolar Coneentrations of Nitric Oxide," Sensora, V11:N2(7273), February 1994 (ISSN 0746-9482).

10. Rutuell, B. F. et al, "Protedure for Sempling Deep Subsurface Microbial Communities in Unconoolidated Sediments". Ground Water Monitoning Reviess 12(1):96. 104, Winter 1992 (ISSN 0273-1926). 


\section{HUMAN GENOME}

DOE supports research to stimulate the acquisition of knowledge regarding the molectlar structure of the human genome and to make this information and related biological, chemical, and physical resources readily available to interested users. Such knowledge will (1) markedly improve the ability to estimate risks to humans exposed to low levels of radiation and cheznicals by clarifying the basis for variation in human susceptibility to such exposure, (2) form the basis for individualizing radiation protection and monitoring needs, and (3) facilitate the identification and isolation of genes mvolved in human diseases and disorders. There is alas the potential of diagnosing early disease correlates years before clinical symptoms appear, Areas of interest include developing more efficient DNA-sequencing technologies, improving computational capabilities for acguiring, storing, and analyzing human chromosone DNA-sequence data, and disseminating new information with appropriate learning gids. Close interactions with one of the $\mathrm{DOE}$ laboratories can be beneficial in the development of a grant application.

Grant applications are invited only in the following subtopice;

a. Development of Improved DNA Sequencing Technologies-Increaged use is being made of DNA sequencing in biotechnology, cancer research, gentic toxicology, and molecular genetics. Data derived by DNA sequencing have wide application in a variety of research areas including: design of improved vectors for gene cloning and expression, analysis of the genetic organization of eukaryotic chromosomes, and assessment of envirorimentally induced DNA darage. Grant applications are sought for improvements in techniques and instrumentation to substantially guxgment present capabilities in DNA sequencing technologies. Innovative new approaches to increasing the speed of sequeneing by orders of magnitude, error-free performance, and low cost per base are of interest. Developments might include: (1) new automated instrumentation for DNA preparation and amplification; (2) improved and novel sets of labels and/or complementary instrumentation for quantifying and distinguishing co-resolved labels in seçuencing instruments; and (3) new approaches to sequencing (chernical, enzymatic, or physical). b. Improved Systems for Management and Interrogation of DNA Clone Libraries-Grant applications are sought for innovative approaches for the maintenance and interrogation of librarios of DNA clones for the discrimination between, and isolation of, sought library members. Applications must propose technologies or approsches that will enhance the capacties of small laboratories to process large libraries, or to enable much more cost effective library processing services by private sector organizations. Coupled improvements are sought, for exgmple, in the massively parallel growth of clones andor amplification of clonal DNAs, automation of pooling strategies for polymerase chain reaction screening, or miniaturization of DNA dot blots for subseguent interrogations with DNA probes.

c. Rapid and Automated Methods for Polymorphiam Screening-Grant applications ere sought for innovative approaches thet could repidly sereen for the presence of mutations or polymorphisms in selected genes of a large number of individuals. Applications should propose technology that can quickly and officiently process many DNA samples. Also, applications should use technologies that can be autometed. The proposed approach should address screening of multiple menes simultaneously from one DNA sample. Approaches that are amenable to the integration of several complementary techniques are encouraged. Issues that should be considered must include one or more of the followinge (1) heterozygosity (detecting only one mutant copy of a eene or polymorphism of a heterozygote is important); (2) sample heterogeneity (biological samples, e.g., tomor biopsies, may contein cell subpopulations with different somatic mutations, and it is important to detect alterations in only a fraction of the DNA in the sample); (3) small DNA sequence changes, e.p., point mutations and small deletions (techniques are also needed to accurately determine the exact DNA sequence of the variants); or (4) gene amplifications and deletions (techniques are needed to detect more rapidly and efficiently these larger alterations in DNA).

d. Educational Materials and Information Technologies-Information from the Human Genoms Project is expanding rapidly and has the potential to affect our everyday lives in many ways. Educational materials are necessary to aid and facilitate nse of this expanding knowledge resource. Grant applitations are sought for the development of innovative materials or

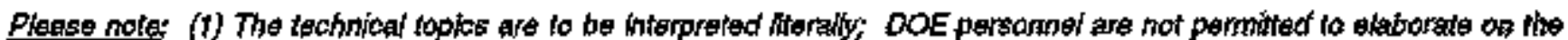
48 banguage in the iechnioal topics. (2) The award selection process is extremely conpotitive. Last year, ondy I out of ti grant

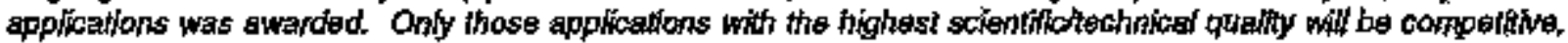


information dissemination techniques that will help to inform the public abont the benefits and challenges arising from this progrem. Applicents should have sufficient knowledge and expertise to allow them to communicate with scientists working on the project and to rapidly and efficiently research the appropriate literature sources needed to forth the basis for developing high quality commonication vehicles. The materials and techniques to be developed by these projects in Phase II could be designed for use at the high school, undergreduats college, or graduate level (d.g., biological, physical, and social sciences), or by the lay public, including politicians and the legal and medical professions. The products, to be commercialized in Phase III, would smpport the dissemination and use of the information arising from the project and would include all types of educational media (e.g. printed, audio and video tapes, films, and computerized tutorials). Areas of interest include molecular biology, human gentios, computational biology, automation, and robotizetion. Also of interest are topies involving ethicel, lestal, and social issues, espectially thase dealing with the privacy and confidentiality of genetic information.

\section{Bibliography}

1. Adams, M. D., et al. "A Model for High-Throughput Autourated DNA Sequencing and Analysis Core Facilities," Nature, 868:474-475, March 31, 1994 (ISBN 94181028).

2. Collins, F. C. and D. G. Galas, "A Naw Fyve-Year Plan for the U.S. Human Genone Project," Eelence, 262:43-46, Otober 1, 1993 (ISSN 0086-8075).

3. Cotton, R. G. $\mathrm{H}_{+}$"Dotection of Mutatione in DNA," Gurrent Opinion in Biatechnology, $\$(1): 24-30,1998$ (ISSN 94039661).

4. Edmond, C. G., ot al, Procedings of the Relevance of Mass Spectrontetry to DNA Seqtence Determination: Research Neads for the Human Genome Pragram, CONF-9004251-\$UMM, Report No. PNL-3A-18979, U.S. Department of Energy, Washington D.C. 1890 (N'TIS Order No. DE91004117/. $\mathrm{AB}$ ).*

5 Goad, W. B., "Computational Analyais of Genetic Sequences," Annuel Roview of Biophysics and Biophyeical Chemietry, 16:79-96, 1986 (ISSN 0888. 9182).

6. "Humar Genome 1991.92 Program Report" U.S. Department of Energy, (NTIS Order No. DE92040485).*

2. Hunkepillar, $\mathbf{M}_{+}$ef el, "Large Scale and Automated Sequente Determination," Stience, 254:69-67, 1991 (ISSN 0086-8075).
8. Kautman, D. L. et al, Detection of Point Mutatione Aasociated with Genetic Diseases by an Exan Scanning Technque," Genomice, 8(4):656-663, December 1990 (ISSN $91115 \$ 22)$ ).

9. Korenberz, J. R. et al, "Jieing Fluorescence In-situ Hybridization (FIEH) in Genome Mapping," Trenda in Biotechnolory, 10(1-2):27-32, 1992 (ISSN 0167-9430).

10. Lander, E. S. and N. J. Schork, "Genetic Dhesection of Complex Traitz," \$eience, 265:20\$7-2048, \$eptember 30. 1994 (I8SN 0083-8075).

11. The Michie Cor "Pratection of Human Subjects," Code of Fedoral Rerulationg, Lavel 2:1oi2a, Title 10, Chaptor III745, 10 CFR 745.101, 1994.**

12. Murakami, Y., et al, "Detection of Aberrationa of the p5s Alleles and the Gene Tranteript in Human Tunor Cell Lines by Single-Strand Conformation Polymorphiem Analysio," Cancer Regaarch, 61(19);8960. 3361 July 1, 1991 (ISSN 0000-5472).

18. Murray, J. C., at al, "A Comprehensive Hurason Linkage Map with Centimorgan Density," Sciences 265+2049. 2054, September 30, 1994 (ISSN 0036-8075).

14. Trainor, G. L., DNA Sequencing, Automation, and the Human Genoms, Analyticel Chemistry, 62(5):410-426, March 1, 1990 (IsSN 0009-2700).

15. White, M. B., at sl, "Dotecting Single Bane Substitutions as Heteroduplex Polymorphiems," Genomicg, 12(2):30I-\$06. Felruary 1992 (ISSN 08800. $7643)$.

\footnotetext{
* Ses Bection 7.1

* Avallable from Superintendent of Dacuments, U.S. Government Printing Offiee, Washington, D.C. 20402
}

\section{COMPUTERIZED PROCESSING OF BIOLOGICAL DATA}

DOE supports biological research programs and research infrastructure that require the application of innoyative database and software engineering to problems of biological date and computational biology. These programs involve human genome research, health effects of radiation and environmental agents, structisral biology infrastructure and researth, bioinformation infrastructure, and the development of advanced biomedical technologies. Research and development in these areas will require software tools for the management of laboratory systems and information, data analysis, and information retrieval and nevigation. In addition, improved seientific databases and associated resources will be required. These tools should address the major chaltenges facing 
bjology today, particularly in the analysis of structure and function of genomic DNA sequences and proteins.

\section{Grant applisations are invited only in the following subtopics:}

a. Development of Improved DNA Sequence Data Acquisition, Analyajs, and Procegsing -As detailed in the goals for the human genome program, advances in DNA sequencing tochnolopios are increasing the volume of data generated from DNA sequencing systemg. After these DNA sequencing technologies are implemented at genome research sites, it is anticjpated that these sequencing technologies will also be widely adepted for use at other sites in routine medieal diagnostics, biotethnological applications, and biomedical research. Increasingly automated procedures and integration of steps in handling data and materials will be needed. Grent applications are sought for innovative design, evaluation, or optimization of sofowere and related developrents that will signifieantly improve, integrate, and eutomate two or more processes associated with large-scale DNA sequencing efforts. Such processes include: determination of appropriate sequencing templates from the physical map of a genomic region; (2) automation of handling and processing of sequencing templates; (3) autoration of handling and processing of the results from the DNA sequencing instruments; (4) prediction of meaningtul sequence simitarities between newly discovered gequences and the sequences of previously characterized genes; (6) altomation of sequence data analysis and annotation; and (6) submission of sequence and associated data to community databases. Applicants must describe the user community that will be the initial target for these innovations and how they will interact with members of that community to determine users' needs.

b. Software to Facilitate Accegs to Public Databases-Large, complex public databases and data resources now play an increasingly important role in biological research, and access to these databases is important for human genome research, structura] biology research, environmental research, and many other fields. Exemples of these public data resources include the Genome Sequence Data Base (GSDB), the Genome Data Base (GDB), and the Protein Data Bank (PDB). The public databases are, for the most part, available on-line over the Internet via documented application programming interfaces. Software tools are needed thet can facilitate access to distributed, heterogenous data bases; extract data for use by local desktop-based or remote compute server-based analytical tools; maintain connectivity and interoperability in the face of diverse software, hardware, and data schemes at different sites; and buffer against the effects of local system modifications and upgrades. Recently, generic Intermet client-server software such as Mosaic and World Wide Web that access text and other file-based information through the Internet have proven very useful.

Grant applications are sought for innovative design, evaluation, of optimization of sottware to facilitate the analysis and handling of data held in public biological data resources. This includes: (1) vector graphics displays of genomic maps and other biological data; (2) improved ebility to direct ad hoc structured cueries against underlying public biological databases; (3) improved ability to execute queries that are the equivalent of true and outer joins against data distributed at multiple sites; (4) integration of lotal laboratory data with data from networked public databeses; and (5) optimization of improved data annotation, data curatorship, and data subrisission tools to one or more of these public databases. Applications must: be based on the use of Internet (the only exceptions are CD-ROM-based applications, assuming that use of the latter mode of distribution is justified and the issue of semi-annual updates to the date is adequately addressed), demonstrate familiarity with previous and current work in the area, develop interactions with one or more sites already active in computational biology or biological data resources, describe the user community that will be the injtial target for their innovations, and communicate with members of that community to determine the users' needs.

c. Software for Acquisition and Anplysis of $X$-ray Spectroscopy Data-X-ray spectroscopy is playing an increasing role in providing key data about metal jons in molecules of biological importence. Information on structural parameters as well as on the oxidation state of these ions can be abtained with x-ray spectroscopy, and such data are often not accessible by other techniques. An obstacle to the widespread use of this technique is the difficulty in obtaining consistent, reproducible analyses of the spectral data collected. Grant applications are solicited for the development of software that will facilitate accurate, reproducible interpretation of electronic structure dats from $x$-ray spectroseopy experiments on biologital molecules and

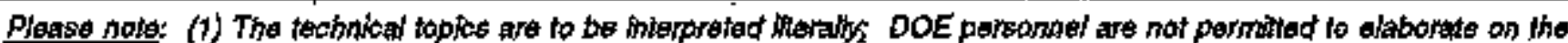

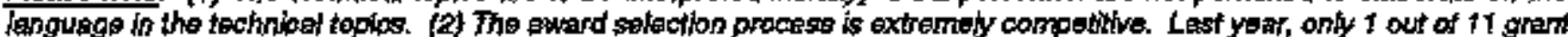

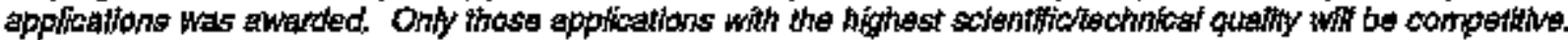


environmental contaminants. The software must address integration of data collection and data analysis.

\section{Bibliography}

1. Collins, F, and D. Gaias, "Revised Fve.Year Plan for the U. S. Human Genome Projact," October 1, 1908 to September 30, 1998; Science, Octabor 1, 1998, V262(43).

2. Cuticchia A. J., et al, "The GDB Human Genone Data Base Arno 1998," Nucleic Acids Research, July 1, 1998, V21:N13(3003-3006) (ISSN 0805-1048).

a. "DOE Expands LANL Sequence Date Management," Human Genome News, November 1998, VbtN4(4)."

4. "Genome Centers Promote Collaboration," Humen Genome News, March 1998, V4:N6(1-9).*

5. "Hatking the Genone", ScientiBc American April 1992, 266:128-137 (ISSN 0036-3793).

6. "Human Genome 1991-1992 Program Report", U.S. Depertment of Energy, June 1992, 248 pp., Report No. DOEJER-0544P (NTIS Order No. DE 2040465) *-

7. "Human Genome 1993 Program Report", U.S. Department of Energy, March 1994, 24 pp., Report No. DOERR-0611P (NTTS Order DE94009457)**

8. Uherbscher, E. "ORNL Announcea genQuest and XGRA卫, "Human GenomeNews, January 1994, V5:N6r 7 . 8),*

9. "Structural Biology and Synchrotron Radiation: ABsegsment of Resources and Needs", Reports Spanaored by Blosync, July 1991, *1**

10. "Trebnologies for the Future: Opportunities and Neede in Structurs Biology and Molecular Medicine", Bethegda, MD, National Institutes of Health.****

Available from Kumen Genome Management Information System, Oak Rỉge National Laboratory, 1060 Commerce Park, MS-6480, Oak Ridge, TN 37831 (Telephone 613-s76-6669)

** See Section 7.1

*at Available from the Structural Biology Synchrotron Users Organization, Department of Biological Sciences, Purdup University, West Lafayetts, IN 47907

**** Available from the Office of Scisnce and Health Reports, NCRRNIH, Westwood Building, Room 860, Bethe日da, MD 20892 (Telephene 301-594-7988)

\section{ATMOSPHERIC MEASUREMENT AND SAMPLING TECHNOLOGIES}

World-wide energy production is modifying the chemical composition of the atcoosphere and is linked with environmental degradation and humen health problems. The radiative transfer properties of the atmosphere may be chariging as well. Various technological developments are needed for the longterm monitoring of these changes to support a strategy of sustainable and pollution-fiee energy development, for the fature. The following four subtopies focus on these needs. Subtopic a concerns gas-phase absorption measurement in the 8- to 14-micron bend. Subtopic b concerns the development of jmproved radiometric instruments, and subtopics $\mathrm{c}$ and d concern the application of ummanned aerial vehjcles (UAVs) for highaltitude measurement and sempling.

Grant applications must propose Phase I bench tests of critical technologies. Critical technologies are those components, materials, equipment, or processes that significantly limit current capabilitjes in the spectific subtopic area. For example, gxant applications proposing only computer modeling without physical testing will be considered non-responsive. Grant applications should also describe the purpose and benefits of any proposed teaming arrangements with government laboratories or aniversities in the technical approach or work plan. Applications for ell subtopics should support claims of commercial potential for proposed technologies, (e.g., endorsements from relevant industrial sectors, market analysis, or identifieation of potential spin-offs). Grant applications are invited only in the following aubtopica:

a. Mid-Infrared Range Absorption-Grant applications are sought to develop sensitive methods of measuring absalute absorption losses in gas phase samples in the infrared region, specifically the 8- to 14 micron repion. The proposed technolopies should have sigrificantly improved performance characteristjes over existing field transportable monitoring devices. The method must be absolute and eannot rely on a calibration measurement because operations at a remote site may limit access to the instrumentation. Applin cations should discuss how the tochnology can be adapted for autonomous operation at remote sites on battery power. Phase I must experimentally demonstrate a capability to meet all the above requirements, address potential sources of instrument error associated with self-calibration, and develop design features to enable operation at a remote site for as long as one year. In Phase 11, the proposed apparatus must be constracted, and its capabilities must be demonetrated. Applications that make only incremental advances to existing technologies will be declined. 
b. Radiometric Instrumentation-Measurements of columin-integrated shortwave solar radiation $(0.3$ to 3.0 micrometers) and thermal radiation (3 to 100 mierometers) provide valngble information about the chemical and physical state of the atmosphere as well as the skin temperature and reflectivity of the earth surface. Both direct and diffuse components of incident solar radiation are measured. Current instrumentation for broad-band solar radiation include pyranometers, pyrheliometers, and rotating-shadowband radiometers. Spectral measurementis are typically made with scanning-filter photometers, rotatingshadowband spectrometers, and spectroradiometers. Broad-band precision infrared radiometers, interferometers, and grating instruments are used for measuring the thermal radiation from the earth surface and atmosphere. Grant applications are solicited for the developonent of novel radiometric instramentation or radiometer somponents that (1) improve current performance (e.g., eliminate angle of incidence, temperature, pressure, and humidity effects on detectors, precision optical components, and windows), (2) reduce drift or caljbratton requirements, (3) significently reduce the cost of ancillary equipment such sis solar seekers and trackers without degrading performance, or (4) extend the range of low-cost spectsal instrumentetion into the ultraviolet $-B(0.28$ to 0.32 micrometers) and near infraced (2 to 50 micrometers) regions. Appliennts may focus on critical components and ancillary equipment for radiometers including: detectors, radiation standards and calibration methods, filter systems and monochromators, and solar tracker/seekers. Applications that make only incremental improvements to existing radiometric devices will be declined.

c. Unmanned Aerial Vehicles Performance Enhancement-Significant advances in unmanned aerial vehicle (UAV) performance are required to achieve sugtained flight at altitudes of up to $20 \mathrm{~km}$. Grant applications are sought for novel technologies that enhance current flight duration and/or altitode capabilities of UAVs, improve in-flight safety and/or reliability, or reduce operating and/or construction costs. Also of interest are de-icing methods for UAVs that work at mid-altitude or in cirrus clouds with signifiegnt amounts of super-cooled water vapor. For de-jeing methods, applications must include an analysis to determine where icing is likely to occur and tochniques to detect the presence of ice in flight.
Proposed work must result in a significant capability enhancement. Technologies must be developed to the extent that they can be demonstrated in an unmanned aerial vehicle flight during Phase II. Phase I grant applications must identify unmanned aerial platforms to be used for this flight demonstretion and include teaming agreaments necessary for the flitht demonstration. Phase 1 grant applications must also address the following design considerations (although the actual design work could be performed in Phase I or II): effects of pressure variations on system performance as the vehicle changes altitude, system reliability for unattended periods of operation ranging from several days to a week in duration, and system monitoring and control input requitrements (i.e., temperature, pressure, and humidity). Applications that make only incremental improvements to existing technologies will be declined.

d. Sensorg for Unmanned Aerial VehiclesUnmanned aerial vebicle (UAV) systems used for atmospheric radiation measurement. have special sensing requirements that are unique to their mission. Grant applications are sought for: (1) Sensing devices to accurately measure water vapor concentrations to altitudes of $20 \mathrm{~km}$. Water vapor measurement should be accurate to within $\pm 10 \%$ at an altitude of $20 \mathrm{~km}$. (2) Compact devices for precisely determining the orientation of UAVs with respect to the sun. High accuracy megsurements of the solar flux require knowing the instrutoent orientation with respect to the sun to 0.1 degree at $10 \mathrm{~Hz}$. (3) Sensor stabilizetion systems to maintain sensor orientation relative to either a gea- or solar-referented axis during flight. Systems should be capable of majnteining $=0.5$-degree accuracy for 100-hour UAV flights. (4) Sensing systems to remotely detect and discriminate between liquid and solid aerosols in the flight path of a UAV. The system should provide information that will allow the vehicle to make avoidance maneuvers if necessary. Solid phase particles from plinian eruptions with particle diameters of between 5 and 50 microns at concentrations from 004 to 4 grams per cubic meter must be detectable.

System weight, power, and cost are critical design elements in egch area. Estimates of wejght, pawer, and cost for the proposed technology should be included in the grant application. An understanding of UAV design requirements must be clearly shown in the grant application. Applications that make only 
incremental improvements to existing technologies will be declined.

\section{Bibliography}

1. Alzheimer, J. M., et al, Stabilized Platform for Tetherred Balloon Soundinge of Broadband Long-and Short-Wave Radiation, Eighth Symposium on Meteorological Obvertations afld Instrumentation, Anatheim, Calfformia, Jantary $1983,7 \mathrm{p}$, Report No. PNL-SA-21089, CONF. 930198-8 (NTIS No. DE93007876)."

2. Chou, M. D. and L. Peng, 'A Parameterization of the Absorption in the 15 Micron $\mathrm{CO}_{2}$ Spectral Region with Applicetion to Climate Sensitivity Studies," Joumal of the Atmospheric Sciences, 40:2183-2192, September 1983 (ISSN 0022-4928).

3. Ellingson, R. G, et al, "The Intercomparion of Radiation Codes Used in Climate Models - Long Wave Results," Jourzal of Geophysical Ragearch, 96:8929. 8969, May 20, 1991 (ISSN 0148-0227).

4. Grant, W. B., "Water Vapor Absorption Coelficients in the 8-18-Micron Spectral Region - A Critical Review," Applied Opticg, 29(4);451-462, 1990 (ISSN 0003-69s5).

5. Hill, M. L., "Designing a Mini-RPV for a World Endurance Record," Astronalutice and Aeronautice, 20:47-54, November 1962.

6. Langford, J. S., Naw Aircraft Platforms for Earth Bystem Science - An Opportunity for the 19908, Proceedings of the 17th Congress, International Council of the Aeronatutical Sciences, Slockholm, Bueden, 1990, 2\$15\$4-1638 (A91-24301 09-01), American Institute of Aoronautica and Aetronautics, Ine., 1990.

7. Melson, W. G., Monitoring the 1980-1882 Bruptions of Mount St. Helens; Compositions and Abundances of Gla9s," Science, 221(4618):1387-1391, 1983.

B. Ruseel], P. B., et al, "Atvanced Ajrcraft for Atmospheric Re日arch," Unmanned Syatema, (4):19-24, 1991.

9. Sukamto, L. M., at al, "Monolithic Microwave Integrated Circuit Water-Vapor Radiometer," NASA Tech Brief 17(9) \#101, Jet Propulaion Laboratory, California Institute of Technology, Pastdena, CA, V-1(156-180), Decamber 1 (991 (ISSN 92-22442).

* See Section 7.1

\section{MEDICAL APPLICATIONS}

DOE is interested in innovative research involving nuclear medicine technologies to facilitate and advance the current state of diagnosis and treatment of human disorders. The DOE Medical Applications program covers a brosd range of energy-selated technologies including nuclear medicine research. The current areas of research in nuclear medicine focus on the development of (I) radiolabeled molecular probes as radiotracers to study in wivo chemistry, metabolism, cell comruunication, and gene expression in normal and disease states; (2) new radionuclide-jmaging systems; and (3) new boron-labeled compounds targeted for use in neutron capture therapy of cancer. Grant applicetions are invited only in the following subtopics:

a. Molecular Medicine Technologies-Grant applications are sought for the development of radiolabeled compounds that could have applications as radiotracers for (1) radionuclide imaging technolocies stich as single photon emisssion computed tomography (SPECT) and positron emission tomography (PET) and (2) the development of boron-labeled compounds that are capable of concentrating in tumor cells in vivo and delivering lethal radiation after netrtron irradiation. Radiochemical, synthetic, and molecular approaches should be given consideration in developing molecular medicine technologies capable of providing a product for nuclear medicine use.

b. Advanced Imaging Technologies-Otrent appljcations are sought for new, sensitive, high resalution instrumentation for radionuclide imaging, which advances the application of radiotracer methodologies for inaging moleculat biology including cell communication and gene expression th vivo. Development of new detector nuaterial, detector astays for threedimensional imaging, software development for rapid data processing, and image reconstruction is of interest.

\section{Bibliography}

1. Barth, R. F., et al, "Boton Neutron Capture Therapy for Cancer. Realittes and Prospects," Cancer, 70 12:29903007, December 15, 1992 (ISSN 0008-543X).

2. "DOE Plenning Workshop on the Advanced Bionedical Technology Initiattve." Report of a Workehop CoSponsored by the Department of Energy (DOE), Office of Enerby Research and Office of Drfense Programe held at the Ritz-Carletan Pentagon City, Arlington, VA, Jentudy 11-12, 1994 (NTIS Order No. 94014087)."

8. Nuclear Science Sympositum and Bedical Imaging Conference, San Franciseo, California, Ottober 31. November 6. 1993, Vol 2, IEEE Nucloar and Plasma Sciencess Society, IEEE Catalog No. 93CH3874-6 (ISBN $0-7803-1488-3) * * *$ 
4. Rebe, R. C, ed., "Procedinge of A Workshep on Molecular Nuchear Medidne," Molecular Nuctear Medlaine Workshop, Washington, D.C., January 22-23, 1992, 1192, CONE.9201197 (NTS Order No. DE98010829)**

\footnotetext{
* Ees Egation 7.1

* Available from the IEFE Service Center, 445 Haes Lane, Plecataway, NJ 08854 (Telephone 800-678-4333)
}

\section{HIGH ENERGY PHYSICS EDUCATIONAL AND TEACHING AIDS}

DOE supports an extensive program of basic research in high energy physics. An impartant adjunct to this field is the physies and technology employed for the production of the charsed particle bearns used in the research. Since the DOE mission encompasses not only research but also education in basic sciences, the high enerey physics program is interested in stimulating the development of ajds for teaching the science, technology, and research protesses central to high energy physics and the physics of charged particle beams. The educational levels of interest are high gshool, junior and undereraduate college, or first- or second-year graduate level college. It is not required that grant applications target all of these levels; targeting one or two levels may be more appropriate for a proposed teaching aid. The stindent participation ean range from totally student self-paced and interactive through complex demonstration devices to be operated by a lecture-demonstrator.

The teaching eids of interest may be laboratory or lecture demonstration hardware or software, student laboratory apparatuss, or self-teaching kits or software for solfinstruction in school, at workshops, or by individuals at home. The focus for developing hardware as teaching aids should be on highly innovative, safe, inexpensive, and simple devices. Interactive devices or software are desirable, but not exclusively so. Apparatus must be in compliance with applicable Federal, state, and local regulations regarding radiation and radiological safaty. In onder to be considered for funding, grant applications must explicitly show and demonstrate the relevance of the proposed work to education in high energy physics, particle astrophysics, or the adjunct physics and technology of charged particle beams. Grant applications are invited only in the following subtopicgs

a. Partfole Detectors-Grent applieations are sought for teaching aids that employ modem particle or radiation detection technologies in highly innovative and inexpensive educational demonstrations or projects illustrating how research is accomplished in high energy physics. Devices should be easy to use and maintain. Teaching aids in this area should include supporting electronics and, where applicable, software support. Interfices to personal computers typically used in high schools and colleges are desirable, as is supporting software that cen provide simple pulse analysis, histogram, track drawing, etc. Examples of educational devices that might be appropriate include, but are not limited to, stintillator telescopes, $56 \mathrm{mi}-$ conductor detectors, $\mathrm{NaI}$ or other crystal detectors, and cosmic ray and wire chamber detectors, as well as associated experimental packages.

b. Electronica Used in High Bnergy PhyoicsGrant applications are sought for the innovative development of simple, inexpensive educational devices that demonstrate the principles of electronically processing data from particle detectors. For example, such devices might include pulse shapers, pulse-beight analyzers, discriminators, and trigsering circusts. Interfacing these devices to personal computers typically used in high schools and colleges is desirable as is computer software for displaying and analyzing outputs from the processing hardware. In addition, the development of software products for lllustration and simulation of particle detection systems will bo considered.

c. Apparatug for Teaching the Physicg and Technology of Charged Paxticle Beams-Grant applications are sought for the development of novel and innovative educations tools to demonstrate the physics of charged particle beams and charged particle beam optical systems in devices such as charged particle accelerators, storage rings, linear colliders, beam transport lines, and charged particle sources. For example, these might include devices that integrate such elements as magnetic and electrostatic beam steering and focusing, beam position monitoring, beam imaging, and beam eurrent monitoring, as are commonly found in electron/ion foensing and transport channels, accelerators, storage rings, electron mickoscopes, or television thubes, 
d. Software Tutorials-Grant applications are sought for the development of creative and innovative multimedia products, integrating video, graphics, animation, sound, and interactive techniques, for direct use by students to better understand and learn key concepts in high energy physics, particie astrophysics, or the physics of charged particle beams. These educational products could be quizzes, "games", and/or simulated analysis of real physics results. Examples of educational tutorials that could be developed include the "Standard Model" of particle physies, and the history of this model; highlights of major research findings in particle physics over the past three decades; and the design, use, and "dissection" of particle detectors, thared particle optics systems (i.e., particle beam lines, electron microscopes, etc.), and various types of accelerators. Substantial video footage of detectors and accelerators is available from the Department of Energy national laboratories.

\section{Bibliography}

1. Brauker, H., ot al, "Tracking and Imaging Elementery Particles, - Scientitic American 26.5(2):58-63, August, 1991 (ISSN 0036-8733).

2. Cahn, R. and G. Goldhaber, The Experimental Foundatione of Particle Phygict, New York: Cambridge University Pre8s, 1991 (ISBN 0-521-42425-9).

3. Carrigan, R. and W. P. Thower, Particles and Forces at the Heart of the Matter, New York: W. H. Freeman and Co., 1989 (ISBN 0.7167-2070-10).

4. Davideon, C., "The Man Who Made Computers Personal," Now Scientist, 1S8(1878):32-85, June 19, 1998 (ISSN 0262-4070).

5. Dodd, J., The Idaas of Particle Physice: An Introduction for Scientists New York: Cambridge Universtty Press, 1984 (ISBN 0-521-27322-6).

6. Jones, G. T., "The Physical Principles of Particle Detectors," Phygics Teacher, 29(9):\$78-585, Decernber 1991 (ISSN 0031-921X).

7、 Elementary-Particle Phydics, Phyaics Through the 1990B Series, National Research Couneil, Washington, D.C.: National Acedemy Prese, 1986 (ISBN 0-309-03576-7).

8. Quint, H. R. et al, Teachers' Resource Book on Fundamental Particles and Interactions, Lawrence Berkeley Laboratory, Berkeley, CA, Report LBL-26669, January \$1, 1989 (NTIS Order No. DE89018418).*

9. "Summaries of Resegrch in High Energy Physica," U.S. Depertment of Energy, Washington, D.C., Report DOEER 0358, Notamber 1987 (NT'Is Order No. DE88002816)."
Sẹ Section 7.1

\section{TECHNOLOGY AND INSTRUMENTATION FOR HIGH ENERGY ACCELERATORS}

\begin{abstract}
The DOE High Energy Physics program supports a broad research and development effort in the science, engineering, and technology of charged particte accelerators, storage rings, and associated apparatus. Advanced $R \& D$ is needed in support of this program in the following areas: (1) new concepts for acceleration, novel device development, and computer soltware that will contribute to overall advances in accelerator technology applicable to the High Energy Physics program, (2) high peak power radio frequency (RF) technologies, (3) advanced cryogenic, superconductor, and superconducting magnet technologies, and (4) special charged particle beam and high energy physics instrumentation. Relevance to applications in high energy physics must be explicitly described and will be a factor in selection. Advanced accelerator $R \& D$ more appropriate to applications in nuclear physits or heavy ion fusion is spectifically excluded from this topic and should be submitted under Topjes 18 and 22 , respectively. Grant applications are fnvited only in the following subtopics:
\end{abstract}

a. Advanced Accelerator Concepta, Technology. and Related Software Development-Grant appljcations are sought to develop new or improved acceleration concepts and devices to provide very high gradient ( $>100 \mathrm{MeV} / \mathrm{m}$ for electrons and $>10 \mathrm{MeV} / \mathrm{m}$ for protons) acceleration of intense bunches of particles. Stageability, beam stability, manufacturability, and high wall plug to beasn power efficiency must be addressed in detail.

Grant applications are also sought for the development of permanent magnet, charged particle optical elements. Examples include, but are not limited to, dipoles, quadrupales, higher order multipole correctors for use in small electron linear accelerators, and solenoids for use in electron-beam or ion-beam sources or for klystron or other RF amplifier tubes operating at wavelengths from 0.1 to $10 \mathrm{~cm}$. Magnets made with very high residual magnetization, radiation resistance, and thermal stability (low variation of field strength with temperature) are of particular interest. 
Grant applications are invited for development of new or improved computer software specifically for the design or study of charged particle beam optical systems, accelerator systems, or accelerator components. Such applications should incorporate the innovative development of user-friendly interfaces with emphasis on graphical user interfaces and windows. Grant applications are also solicited for the conversion of existing codes to incorporate such interfaces, provided that existing copyrights are protected and that applications include the authors' statements of permission where appropriate.

Also sought are grant applications for the design and prototype fabrication of small inexpensive ( $<1$ millian) electron sources for use in advanced accelerator R\&D laboratory experiments. These sources should be in the energy range of 5 to $35 \mathrm{MeV}$, and provide on the order of $10^{9}$ electrons in a bunch less than 5 picoseconds long. The normalized transverse beam emittance should he less than or equal to $5 \pi$ mm-mrad, and the device should operate at greater than $10 \mathrm{~Hz}$ pulge repetition rate. RF photocathode sources (robust, with quantam efficiencies $>0.1 \%$ ) operating at output electron beam energies $>3 \mathrm{MeV}$ and/or the required laser ôtive systems are included among these sources.

b. Radio Frequency Acceleration-Grant applicetions are invited for research on very high gradient $R F$ accelerating structureg, normal or superconducting, for use in accelerators and storage rings. Gradients $>100$ $\mathrm{MeV} / \mathrm{m}$ for electrons and $>10 \mathrm{MeV} / \mathrm{m}$ for protons in normal cavities are of particular interest, as are means for suppressing unwanted higher-order modes. Means for achieving unloaded voltage gradients $>20 \mathrm{MeV} / \mathrm{m}$ in superconducting cavities are of interest, as are methods for reducing surface breakdown and multipactoring (snch as surface coatings or special geometries) and for suppressing unwanted higher order modes. Grant applieations should be for devices operating at wavelengths from 0.1 to 25 en.

There is also interest in new concepts, approaches, and instrumentation for producing high peak power $(>150$ MW), narrowband, low daty-cycle, low pulse repetition frequency (approxómately $1 \mathrm{kHz}$ ) pulsed RF amplifiers operating at $1.0 \mathrm{GHz}$ or higher frequency for application in large electron/positron linear colliders. Potential electrical efficiencies greater than $45 \%$ are considered essential. Also Bonght are higher efficiency (>65\%) $1,0 \mathrm{GHz}$ or higher frequency sources with a few MW power, 2 msec (millisecond) pulse length, and 10-
$100 \mathrm{~Hz}$ repetition rate. In addition, low-cost, very efficient, pulse power modulators in the $250 \mathrm{kV}$ to 1 MV range are also sought for the above pulsed RF systems.

c. Cryogenic, Superconductor, and Super. conducting Magnet Technology-This subtopic addresses only those cryogentc, super-conductor, and superconducting magnet development technologies that support dipoles, quadrupoles, and higher ordier mulcipole corrector magnets for use in accelerators, storage rings, and charged particle beam transport systems. Grant applications on new and significantly improved eryogenic devices and systems for helinm service in the tamperature range 2 to $20 \mathrm{~K}$ are sought, e.g., development of new or significently improved heat exchangers and rotating machinery (tarboexpanders, circulating pumps, and compressors).

Improved instrumentation directly applicable to the testing of superconducting magnets, including the measurement of local strain, temperature, and magnetic field, is sought.

New or improved materials and related processing techniques are sought for high critical-current, high critical-field conductors to produce low stabilizer (Ca, A) to superconductor ratio, multifilamentary wire for use in very high-6eld magnets $(B>8 \mathrm{~T}$ ). Examples of property improvements include higher critical-current. densities, higher critical fields, reduced degradation of these properties as a function of applied strain, and process improvements which result in equivalent, performance at reduced cost. Examples of materials of interest inclade: niobiam-titaniom, niobium-teantalum. titanium, the so called "A-15" compounds (e.c., njobiom-tin), and Chevrel phase superconductors.

d. Special Instrumentation-Grant applications are invited on novel devices and techniques in the areas of beam monitors, beam optics, and instrumentation for high eneroy physics research, as spetified below.

Novel charged particle beam monitors are sought to measure the transverse or longitudinal charge distribution in small radius ( $<5 \mathrm{~mm}$ diameter), short (<10 mm) relativistic electron or ion beams. Also sought are devices capable of measuring and recouding the Schottky spectrum of these beams. Any proposed techniques should be nondestructive to the besms monitored and have computer-coupatible readouts.

Please nole; (1) The technical toptes are to be interpreted Heralt; DOE personnel are not permitted to otaborate on the

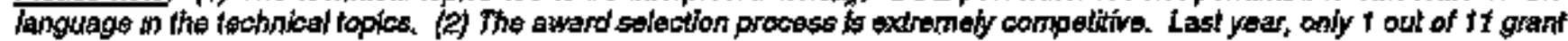

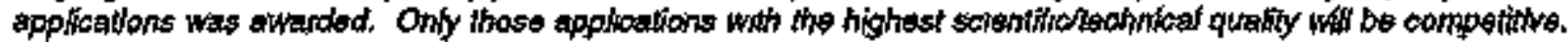


Novel experimental techniques, instrumentation, materials, and systems are sought that either extend basic high energy physies experimental research capabilities or result in less costly and less complex apparatus (e.g., improved or less castly calorimeters or vertex detectors).

Grant applications with a major emphasis on digital instrumentation, digital processing or data triggering, handling, or analysis techniques or hardware should be considered for Topic $\mathbf{1 6}$.

\section{Bibliography}

1. Corneliuesen, 9. T., ed., IRRE Particle Accilerator Confarence, 15th Biennial Particle Accelertator Conference, May 17-20, 1993, Washington, D.C. (IEEE Catalog No. 93CH3279-7).*

2. Duggat, J. L. and I. L. Margan, "Application of Accelerators in Research and Indisatry 92 - Proceedings of the 12th Internationsl Conference on the Application of Accelerators in Regesrch and Industry, Dention, TX, November 2-5, 1992," Nucloar Instruments and Methods in Phygics Research, 79 1-4):PR7-RE 1993, (ISSN 0168. $5 \bar{b}$ X).

3. Hegarty, $\mathrm{S}_{\text {, th }}$ al, ede., Joint International LeptonPhaton Symposium and Europhysics Conference on High Energy Physics, 2 vols., Teaneck, NJ: World Scientific Publicetions, 1992 (ISBN 981-02-0924-3).

4. Jashi, C, and T. Katsouleas, ads., "Laser Accoleration of Particles", AIP Conference Proceedings No. 130: International Worthshop on Laser Acceleration of Particles, Los Angeles, CA. Janwary 1885, CONF-850128 (NTIS Order No. T185017258).**

6. Kittel, P., ed., "Advances in Cryogenic Engineering" Procesdings of the Tenth International Cryagenic Moterials Enginearing Conference, Albuquerque, NM, July 12.16, 1993, Yol. a9, New York: Plenum Presk, 1994 (ISBN 0-306-44864-8).

6. Mills, F. E., ed., "Advanced Accelerator Concepta," AIP Conference Proceedings No. 166: Aduanced Accelertior Concepts Conference, Madison, WI, August 21, 1986. New York: American Institute of Physics, 1987 ***

7. Reed, R. P., eds., -Advantes in Cryogentc Enginearing Materials," Proceedings of the Tenth International Cryogenic Materials Engineering Conference. Albuquergue, $N M, J u l y$ 12-16, 1993, Vol, 40, Now York: Plenum Press, 1994 (ISBN 0-306-44920-8).

8. Raвgbach, Ju, ed. High Energy Accelerators, 92; Procendings of the Fifeenth International Corference, Teaneck, NJ: World Sctentific Publications, 1998, (ISBN 9-8102-1152-X).****

9. Rostoker, N. and M. Reiser, ede., Proceedings of the Third International Conference on Collective Methods of
Aceeleration, Laguna Beoch, CA, May 22.25, 1978, Now York: Gordon and Breach/Hartwood Academic Publíshera (ISBN 9-8102-1152-X).

10. Sanford, J. R. eld, Procesedings of the $X X V$ International Conference on High Energy Phyrics, Datlas, TX, August 6-12, 1992, American Institute of Physics, New York, NY, 1998.***

11. "Sumumarles of FY 1984 Research in High Energy Physica", U.S. Depertment of Energy, Washingtan, D.C., December 1984, DOEJER.0210 (NTIS Order No. DE85005641),"**

12. Wurtele, J. S., \&d., "Advanced Accelorator Concepte," AIP Confurence Proceedings No. 279: Adurunced Accelerator Concepts Conference, Port Jefferson, Long Islond, NY, June 14, 1992, American Inetitute of Physics, Now York, NY, 1998.***

18. 1992 Applited Supercanductioity Conference, Chicogo, IL,

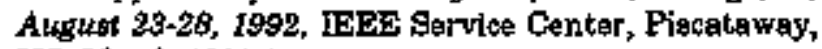
NJ, March 1998."

\footnotetext{
* Available from the IREE Service Center, 446 Hose Lane, Placateway, NJ 00854 (800-678-4983)

** See Section 7.1

*** Availeble from American Inetitute of Physica, care af: American Intamational Distribution Corp., 64 DEPO Road, Colcheoter, VT 05448 (Telephone 800-489-2665

**k** Avallable from World Scientific Publishing Co., Inc, 687 Hartwell Strąet, Teaneck, NJ 07666
}

\section{HIGH ENERGY PHYSICS DATA PROCESSING AND DETECTOR INSTRUMENTATION}

DOE supports research and developtaent in a wide range of technologies essential to the conduct of experiments in high energy physics or to the operation of the accelerator complexes at the three major DOE high energy accelerator laboratories. The devolopment of advanced technologies for particle detection and for the recording, processing, and analysis of experimental data as well as for the monitoring and contral of accelerator systems and devices are included. Principal areas of present interest include high-speed electronics instrumentation, dats acquisition and analysis systems, special computer systems, computerto-computer networks, computer peripherals, particle detectors and associated data read-out systems, and instrumentation and procedures for the operation and control of particle accelerators. Grant applications must clearly and specifically indicate their particular relevence to high energy physies programmatic 
activities. Although perticle physics detector instrumentation and data processing equipment development and construction are usvally centered in large, onllaborative efforts at major national particle accelerator centers, there are many developmenta] endeavors in collaborative or stand-alone efforts where small businesses can make creative and innovative contributions to the further development of the required advanced technologies. This is equally true for accelerator monitoring and control systems. Grant applications are invited only in the following subtopics:

\section{a. High-Speed Electronic Ingtrumentation-This} subtopic includes:

Components-Grant applications are invited for special purpose chips and devices for use in the internal circuitry employed in large particle detectors. Desirable features include low noise, low power consumption, high packing density, radiation resistance, very high response speed, and/or high adaptebility to situations requiring multiple parallel thannels. Desirable functions include amplifiers, counters, analog pulse storage devices, decoders, encoders, analos-todigital converters, controllers, and communientions interface devices.

Electronicg-Grant applications are invited for circuits and systems for rapidly processing data from particle datectors such as proportional wire chambers, scintillation counters, silicon microstrip detectors, particle calorimeters, and Cerenkov counters. Representative processing functions and circuits inclade low noise pulse amplifiers and preampliffers, high speed counters (>800 MHz), and time-to-amplitude converters. Compatibility with one of the widely used module interconnection standards (e.g, CAMAC, FASTBUS, or VMEbus) is htghly desirable, as would be low power consumptton, high component density, and/or adaptability to large numbers of multiple channels.

Systems-Grant applications are invited for advanced, hjgh speed logic arrays and microprocessor systems for fast event identificetion, event trigger generation, and data processing with very high through-put capability. Sach systems should be compatible with or implemented in one of the widely used module inter connection standards (e.g., CAMAC, FASTBUS, or VMEbus).

Instrumentation Modules-Much of the electronics instrumentation in use in high energy physics is packaged in one of the international module interconnection standards (e.g., CAMAC, FASTBUS, or VMEbus). Grant applications are invited tor modules that will provide capabilities not previously available, for substantial performance enhancement to existing types of modules, and for components, devices, or systems that will enhance or signtificently extend the capability or finctionality of one of the standard systems. Examples inelude large and/or fast boffer memories, single module computer systams (either general purpose or special purpose), display modules, interconnection systems, communication modules and systems, and disk-drive interface modules.

b. Special Computer \$ystems and PeripheralsGrant appliscations are invited for innovative software and hardware for applications in high energy physics experiments, data processing, accelerator control systems, and theoretical computations, including, for example, distríbuted microprocessor systems, patternrecoenition systems, database management systems, code development systems, emulators for high-speed computation, large ecale parallel processors (100k to $1000 \mathrm{x}$ Cray-2 or IBM $3090600 \mathrm{E}$ computational power) for large-scale simulation, and cost-effective, multipleaccess, large-memory systems. Grant applications are also sought for hardware for local and wide area computer-to-computer networks, network switching devices, network monitoring and control instrumentation, cost-effective alternatives to magnetic tape or disk on-lise storage, new approsches to very long-time or large-scale on-line data storage (e.g., optical disk), sntart terminals, scientifie work stations, and enhaneements to CAB-CAM (computer-assisted design and manufacture) systems and devices. A current strong need is for improved devices using the tape cartridge format for digital storage.

c. Computer Software-Grant applications are invited for the production of computer software to meet identifíed computing problems. Areas of interest include (i) computer network management (e.g-, for X.25, DECnet, and TCP/IP), interconnection, and control; (2) transition to ISO network protocols; (3) CAD-CAM conversion between dissimilat systems; (4) systems for the management of very large databases of the type created in connection with the operation of large detectors; (5) general purpose software for controlling and interfacing with large electronic systems; and (6) softwrare for the control of large multiprocessor systems. Grant applications are also sought for softwere for controlling, dater recording,

Please note: (1) The todfinicel topics are to be foterpreted heralls DOE persannel are not permited to elaborate on the

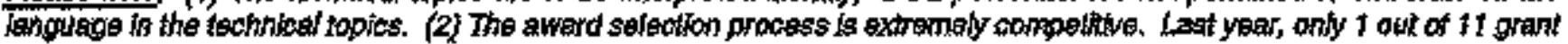

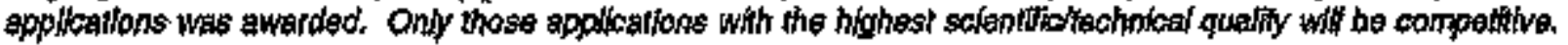


and/or data analysis for a major high energy physics detector system, or for an approach or system that will allow the control, data recording, and/or data analysis software for a large detector to be specified and produced commercially in whole or in part.

Grant applications are also sought for improved software for command and control functions, real time database management, and status display systems encountered in state-of-the-art approaches to acce?erator control.

d. Novel Data Handling Techniques and Systems for Particle Detectors-Grant applicetions are invited for jnnovative approaches to data handling for existing or anticipated experimental techniques and devices that result in more cost-effective or less complex systems for digitizing, handling, or recording detector outputs.

Grant applications are tso invited for improved solutions to the specialized local communications problems encountered internal to large modern particle detectors. Particular aress of interest include the need for ultra-speed highly parallel systems to connect detector device output signals to the external electronic processing site. Grant applications are also songht for improved solutions to the specialized local communication problems encountered in connection with accolerator control systems.

\section{Bibliography}

1. Abashian, A, ed., "Particles and Fields," In AIP Conference Proceedings No. 112, Blacksburg. VA, September 15, I983, American Institute of Physics, 1884 (NTIS No. TI84008600).*

2. Andereon, D, ed, Calorimetry in High Energy Physics: International Conforence, River Edge, NJ: World Scientific Publishing Co., Inc, 1991 (ISBN 981-02-05627).**

3. Bromley, D. A., "Evolution and Ute of Nuclear Detectors and Systems, Parts I and II," Nuclear Instruments and Methode in Physics Ressarch, 162(1-3):1-8, 1979 (IBSN 0020-554X).

4. Dombeck, T., Symposium on Datector Researeh and Development for the Superconducting Buper Collider, River Edge, NJ: World Sefentific Publiehing Co., Inc, 1991 (ISBN 981-02-0445-0).**

5. Duggan, J. L. and I. L. Morgan, eds., "Appljeation of Accelerators in Reenearch and Induetry 1990," In Procedings of the Elewenth International Conference,
Dention, TX, November 5-8, 1890, Nuclear Inetruments and Methode in Physics Reagarch (ISSN 0168-583X).

6. IEEE Standard for WME-bus Extensions for Instrumenkation, VXI-bus, IEEE-1155, 1992,***

7. IEEE Standard Modular Instrumentation and Digital Interface System (CAMAC), Report No. ANSL/EEE Standard 688.1992, February 28, 1982.***

8. Kleinknecht, K. Datectors for Particle Radiation Cambridge, MA Cambridge Uiniversity Press, 1986 (ISBN 0.521-30424-5).

9. Perkine, D. H., An Introduction to High Energy Physicg Addieon-Wesley, 1982 (ISBN 0-201-05757-3).

10. Procedings of the Fifth Conferencs on Real-Time Computer Applications in Nuclear, Particle, and Plasma Physics, San Franctsco, CA, Moy 12-14, 1987, IEEE Trantactions on Nuclear Science, NS-94, No. 4, Auguet 1987 (ISSN 0018-9499)***

11. Reglex, M., et al, Data Analyeis Techniques in High Enersy Physics Expeniments Cambridge, MA: Cambridge UniYarsity Press, 1990 (ISBN 0.521-34 1957 .

12. Standard FASTEUS Modtular High+Speed Data Acquistition and Control System. An American National Standard, ANSUIEEE 960-1989.***

13. Standard for a Vergatite Backplane Bug; VMEbus, IEEE 1014-87, October 1986."4*4"

14. "1991 Nuclear Science Symposium andMedical Imaging Conference," EEEE Transactiong on Nuclear Science. $\$ 9(4): 47$-1500, August 1092 (ISSN 0018-9499).***

* See Section 7.1

** Available from the World Scientifle Publishing Co., Inc., 1060 Main Street, River Edge, NJ 07681 (Tilephone 201-487-9655)

*** Arajlable from the IEbe Service Center, 445 Hoas Lane, Placataway, NJ. 08854. (Telophone 800-678-4383)

\section{NUCLEAR PHYSICS INSTRUMENTATION AND TECHNIQUES}

DOE seeks innovative and novel approaches to technical problems encountered in basic research in nuclear physies. Measurements in this field are performed typically at the limit of kechnical feasibility. Hence, new capability will often exenerate important advances in scientific knowledge. DOE is particularly interested in supporting projects that may lead to advances in detection systems for nuclear physics experiments. Opportunitjes exist for devsloping equipment beyond the present state-of-the-art and outside the usual scope of research and development 
activities at the nuclear physics national accelerator facilities. All grant applications must explicitly show relevance to the nucleer physies program. Grant applications with applicabilfty to nuclear physics research elearly noted are invited only in the following aubtopicise

\section{a. Particle and Photon Detectors and Detector} Meterials-Nuclear physics research has a need for devices for detecting and analyzing charted particles, neutrons, photons, and single atoms with improved ensrgy, position and timing resolution, sensitivity, rate cepability, stability, dynemic range, durability, and background suppression. These devices include: solidstate devices such as silicon strip and silicon drift detectors; photosensitive devices such as photodiodes. single and multi-anode photomultipliers; microchannel plates; and gas-filled detectors such as proportional, drift, streamer, Cerenkov, micro-strip, and straw drift tube chambers; liquid areon and xenon ionization chambers, single-atom detectors using laser techniques, particle polarization detectors, and magnetic spectrometer components and systems. Grant applications are sought to develop: (1) thicker (over one $\mathrm{mm}$ ) segmented silicon charged particle and $x$-ray detectors and associated compact (high density), high resolution electronics; (2) very high resolution particle detectors or bolometers based on semiconductor materials and eryogenic techniques; (3) costeffective production of $n$-type and p-type silicon drift chambers with active areas $>16 \mathrm{~cm}^{2} ;$ (4) detectors with high position resolution, high radiation hardness, smel] surface temperature gradients, and integrated catibrathon systems; (5) resistive materials and methods of production of large area $\left(>100 \mathrm{~cm}^{2}\right)$ conductive surfaces with resistivity in the range of $10^{9}$ to $10^{12} \Omega-\mathrm{cm}$ for electrodes in gas chamber counters, such as substrates in gas micro-strip counters; (B) high precision, low-cost tims of flight detectors and efticient polarizationanalyzing materials; and (7) large arrays of highresolution, room-temperature $\mathbf{H g I}_{2} \mathbf{x}$-rey detectors for use in nuclear spectroscopy. (To minimize Compton zcattering of the reaction gamma rays in these detectors, it is of utmost importance that the masses of the detector packaging and the associated electronics be reduced as much as possible.)

b. Scintillators and Associated Biaterials-Grant applicetions are invited for research and development on new scintillators and new heavy crystals or glasses to serve as scintillators or Cerenkov materials for electromagnetic calorimeter applications. Calorimeter materials in ingle block lengths of up to 20 radiation lengths, which could be produced in large guantities and at low cost, would be of interest. Grant applications are invited for innovative research on new Cerenkov radiator materials with indicas of rafraction up to 1.10 or greater, such as heavy gases, or materials like silica gerogel, with good opticel transparency and long-term stability. New scintillating materials including composite materials with high radiation resistance would be of interest as well.

New scintillation materials are also needed for use in Iarge intermediate-energy photon detector arrays. These materials should exhibit time and energy resolution comparable to $\mathrm{BaF}_{2}$ but with faster scintillation decay time for use in extremely high-rate applications. It is essentia] that the materials have a density and mean naclear charge such that the radiation length is less than $2 \mathrm{~cm}$, and can be fabricated in large pieces (up to 20 radiation lengths) at reasonable costs.

c. Special Nuclear Targets-Grant applications are invited for the development of special nuclear targets only as they specifically address naclear physics research needs. One category of special targets is polarjzed (with nuclear spins aligned) high-density gas or solid targets. Other special tergets include: (1) windowless gas targets and supersonic jet targets, for use with very low energy charged particle beams, and (2) liquid, gaseous, and solid targets capable of high power dissipetion when high intensity, low emittence charged particle beams are used. There is also an interest in new technology for the production of films for targets, strippers, and detector windows.

d. Electronicg Instrumentation and Data Systems-Grant applications are invited for special purpose custom designed integrated circuits and for circuits and systems for rapidly processing data from particle detectors tised in nuclear physics experiments such as gas detectors, scintillation counters, silicon drift chambers, silicon strip detectors, particle calorimeters, and Cerenkov countexs. Representative circuits include low noise amplifiers, analog storage devices, analog-to-digital and time-to-digital converters, and time-to-amplitude convertors. Competibility with one of the widely used module interconnection standards (e.g., CAMAC, FASTBUS, or VMEbus) is highly desirable, as would be low power consumption, advanced packaging, and/or adaptability to a large number of multiple channels.

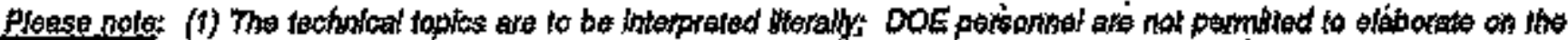

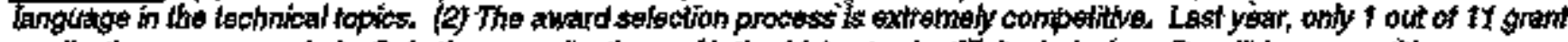

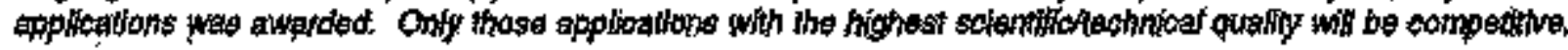


Grant applications are also invited for research and development on devices and systems including bus systems, data links, event handlers, multiple processors, fast buffered time and analog digitizers, generalized software, and packates with improved graphics capabilities for the acquisition and analysis of data specifically addressing needs related to nuclear physics research and development.

\section{Bibliography}

1. Brarsloy, D. A., "Evolution and Une of Nuclear Dotectars and Systems, Parts I and II," Nuclear Instruments and Methods in Physics Research 162(1-3)*1-8, 1979 (ISSN $0029-554 X$.

2. Conceptual Design Raporif for the Solenoidal Tracker at RHIC, Lawrence Berkeley Laboratory Report No. LBL-PUB-5347, June 15, 1992 (NTIS Order No. DE92041174)*

3. Duggan, J. L. and L. L. Morgan, edz., "Application of Acceletators in Research and Industry 1990," Proceadings of the Eleventh International Conference, Denton, TX, November 6-8, 1990, Nuclear Instruments and Methods in Phroics Research (B56/57 1991).

4. Gatti, E. and P. Rehak, "Semiconductor Drift Chamber An Application of a Novel Charge Transport Scheme," Nuclear Instruments and Methods in Physics Regearch, Section A, 225(3):606.614, September 1, 1984 (ISSN $0167-0587$ ).

5. Gatti, E. and P. Rehak, "Silicon Drift Chamberg - First Regults and Optimum Processing of Signals," Nuclear Instruments and Methods in Physica Reaearch, Section A, 2260 1):129-141, September 15, 1984 (ISSN 01670587).

6. Ludlam, T. W. and A. J. Stevent, "A Brief Description of the Relativistic Hegvy Ion Collider Facility." Brookhaven National Laboartory Report No. BNL-49177, June 1993 (NTIS DE93040311)**

7. Makdiski, Y, and A. J. Stevens, eds., Proceedings of the Symposium on RHIC Detectar R\&D, Upton, NY October 10.11, 1991, CONF-9110232, Brookhaven National Laboratory Report No. BNL-52821, 1991 (NTIS Order No. DE930108(5).*

8. Meier, J, et al, "Energy Sensitive Detaction of Heavy Ions with Transition Edge Calorimeters, "Journal of Low Temperature Physics, New York: Plenum Presso, 1099 (ISSN 0022-2291).

9. Olsen, D. K., et al, "The Extension of the HHIRE Accelerators to Produce Radioactive Ion Bearng," Pro. ceedings of the International Conference on Radioactive Nuctear Beams, Louvain-la-Neuve, Belgium, August 19. 21, 1991, CONF-8108236, Bristol, United Kingdon: Adem Híger, 1992 (ISBN 0.7509-0207-0).
10. Proceedings of the Fifh Conference on RealTime Computer Applications in Nuclear, Particle, atd Plasme Physics, Ban Franciseo, CA, May 12-14, 1987, LEEE Trengactions on Nuclear Seience, NS.84, No. 4, August 1987 (ISSN 0019-9499) **

11. "PHENLX Conceptual Design Report," Brookhaven National Laboratory Raport No. BNL-48922, Januery 29, 1993 (NTIS Order No. DE93016759).*

12. Shivakumar, B, and P, Vincent, Procuedings of the Third Workshap on Experiments and Detectors for a Relativistic Hequy Jon Collider, Upton, NY, Juby 18-22, 1989, Brookheven National Leboratory Report No. BNL-E2185, Janusry 1989 (NTSS Order No. DE89008安43).*

13. Sixth Conference on Real-Time Computer Applications in Nuclear, Particle, and Plasma Physics, Williansburg. VA, May 15.19, 1989, IEEE Traneactions on Nuclear Science 38(6) $8721-40 \% 3$, October 1988 (ISSN 00189499)**

14. "Summarjes of BY 1992 Research in Nuclear Physice," U.S. Department of Finergy, DOE/RR-0590, July, 1993 (NTIS Order No. DE98017984).*

* See Section 7.1

** Available from the IEEE Service Center, 445 Howe Lane, Piscataway, NJ 08854 (Telephone 800-678-4833)

\section{NUCLEAR PHYSICS ACCELERATOR TECHNOLOGY}

The Nuclear Physics program of the Department of Energy supports a broad range of activities aimed at research and development related to the science, engineering, and technology of heavy ion, electron, and proton accelerators and associated systems. Research and development is desired that will contribute significantly to overall accelerator technology and applications tailored to nuclear physics scientific initiatives including the Continuous Electron Beam Accelerator Facility (CEBAP) for electron beam energies of up to $16 \mathrm{GeV}$, the Relativistic Heavy Ion Collider (RHIC) with heavy ion energies up to 100 GeV/amu for each beam, Gammasphere, and development of devices and/or methods which would be useful in the generation of intense accelerated beams of radioactive isotopes related to the Radioactive Ion Beam (RIB) facility. Relevance of applications to nuclear physics must be explicitly described. Grant appleations are invited only in the following eubtopies: 
a. Radito Frequency Teohniques-Grant applice. tions are invited on the design and development of improved or advanced concept superconducting and roon temporature materials or components, especially as applied to radio frequency (RF) accelerating cavities used in particle accelerators. Included in this area of interest are accelerating structures and cavities, and peripheral components such g8 altra high vacuum seals, terminations, and cryogenic radio frequency windows. Termination materials for use at 2 to $4 \mathrm{~K}$, compatible with the ultra high vacuum and dust-free environment, and capable of absorbing microwaves efficiently from 2 to $90 \mathrm{OHz}$ ( $>12 \mathrm{~dB}$ retum loss, 2 to $4 \mathrm{GHz}$, S-band waveguide, length $<12 \mathrm{~cm}$ ) are of particular interest. $\mathrm{RF}$ transmission windows for use in an ultra-high vacunm, dust-free enviranment, which have a low secondary emission coefficient, and which do not arc in the presence of incident ionizing rarliation of $3 \times 10^{\circ} \mathrm{A} / \mathrm{tr}^{2}$, are of perticular interest; such windows need to operate at $2 \mathrm{~K}$, and to dissipate less than $10^{\circ}$ of the transinitted power.

Methods of converting RF power, induced in super. conducting cavities by decelerating beams, to direct curtent (dd) power are of interest. The RF power should be induced at a single frequency between 500 and $1500 \mathrm{MHz}$, and the canversion efficiency needs to be greater than $50 \%$.

The avoidance of inclusions in the superconducting material and contamination on the surface of the superconductor is of extreme importance in minimizine field emission, quenches due to localized heat sources, and excessive global heat dissipation. Improvements to accelorating eradients and quality factor $(Q)$ in cavities for both continuous wave and pulsed operation are also desired. Innovative concepts and desions addressing these performance improvements are solicited.

For the pre-acceleration of radioactive bearas, it is desirable to develop superconducting structures which can operate in the velocity regine between 0.001 and 0.01 times the velocity of light, for ions with charge-tomass ratios between $1 / 80$ and 1/240. Structures with large acceptances and which maintain good beam quality in both longitudinal and transverse phase spaces are needed. The development of improved technigues for phase stabilization of low velocity ion acceleration structures is also of interest.
Grant applications are also solicited on methods of fabricating cavities with more than five cells while stit] providing moderate damping of all higher-order modes. Mfore economical methods for the fabrication of cavities and their cryostats are also of importance. Innovative designs for hermetically sealed refrigerators and other cryogenic equipment that simplify procedures and reduce costs associgted with reparability and modification are needed. Grant applications are requeated as well for high duty factor, high power RF systems for RFQs and linacs.

b. Particle Beam Sources (1ncluding electromagnetio beams)-Grant applications are solicited for high-brightness electron beam sources utilizing continuous weve (CW) superconducting RF cavities with integral photocathodes operating at hiph acce]eration gradients. Applications are also requested for particle beam ion sources having improved intenstty, emittence, and range of species. Included are high. charge-state sourzes for heavy ions, sources for negative and light ions, and polerized sources for hydrogen ions and hegvy ions. Power supplies to drive these sources are of interest as well.

Grant applications for the development of jon sources for radiaactive beams are sought. Aspects to be emphasized are: high efficiency, high charge state ions, high temperature operation for coupling to high temperature production targets, and element selectivity, e.g., through the use of laser ionization. The development of methods to increase the charge state of ion beams, e.g., by the ase of special electron-cyclotronresonance ionizers or special stripping technigues, are of interest. Grant applications are also invited on the development of techniques for improving the hith voltage stand-off and reducing the field emission from high voltage electrodes in the presence of work function lowering material (i.e., cesium) to improve the performance of photoemission electron sources.

Grant applications are also requested for the development of technigues and targetry materiels for radioactive beam production. These targets must bo capable of use with beams of protons, neutrons, or heavy ions, with beam power of $10.100 \mathrm{~kW}$, and must be configured for rapid relense of isotopes and clase coupling to an ion source to generate bigh intensity radioactive beams.

c. Accelerator Control and Diagnostice-Grant applications are invited for "intelligent" software and

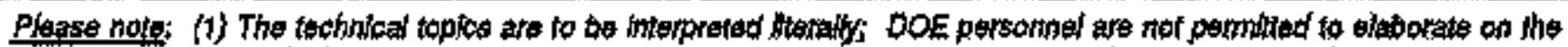


hardware developments which will facilitate the improved control and optimization of charged particle accelerators and associated cornponents for nuclear phystes research, Developments which offer generic solutions to problems in the initial chojce of operational parameters and the optimization of selected beam parameters with automatic tuning are especially encouraged. Grant applìcations requested also include advanced beam diagnostics concepts and devices that provide bigh speed computer-cornpatible meqsurement and monitoring of particle beam intensity, position, emittance, polarization, luminosity, mamentum profile, time of arrival, and energy. The use of advaneed methods such as neural networks or expert systems is appropriate It is especially of interest to develop techniques that are nondestructive to the beams being monitored. Examples of other nuclear physics research needs include increased sensitivity for non-intercepting current, position and profile monitors for ion beams, and methods for on-line monitoring of triggering firom, and transient digitizing of, very short bean bunches (100 pieseconds or less). Measurements of dc charged particle average beam currents in the range 0.1 to 100 ItA to very high precision $\left(<10^{-5}\right)$ are also needed.

d. High Power Solid State Devices-Grant applications are sought for the design and development of solid state devices to replace the currently available 5 kW, $1500 \mathrm{MHz}$ klystrons. The gain should exceed 80 dB, and the device should exhibit long life, costeffectiveness, reliability, and high electrical efficiency.

\section{Bibliography}

1. AIP Conference Procedingsi Fifth Inter nutional Symposium on the Production and Neutralization of Negative Ions and Beams, Brankhaven National Lahoratory, Upton, NY, November 3, 1989, 1990 (ISBN 0-B83187752).

2. AIP Conference Proceedings; International Sympositum on Electron Beam lon Sources and Their Applications, Browkhaven Nátional Laboratory, Upton, NY, November 14-18, 1988, 1989 (ISBN 0-99318-3889).

a. Eeadle, E and V. Castillo, eds., Procedings of the Workshop on Acolerator Instrumentation, AIP Conference Proceedings No. 212, 1990 (ISZN 0-838318-6459).

4. Bickley, M. and J. Kewiech, "The Star, a Dynamicaljy Configured Dataflow Director for Rea]time Control," Procedings of the 1993 Particle Accelerator Conference, Washington, D.C., v8, pp. 1835-1887, 1998 (ISBN 07803-1208-I).
D. Bohn, C. Le, et al, eds., "Status of RF Supercenductivity at Argonne National Laboratary," In Froceedings of the Fifht Workshop on RF Superconductivity at DESY, Hamburc, Germany, Auguat 19-21, 1991, CONF. 9108189 (NTIS Order No. DE2006965)."

6. Duggan, J. L. and I. L. Morgan, eda, Applioation of Accelerators in Resedrch and Induatry '90, Part 1 and 2, CONF-901116-Pt.1, CONF-901118-Pt.2, Amsterdem, The Netherlands: Elaevier Science Publishera B. V., $1991, * * *$

7. Garrett, J. D., et al, "The ORNL Redicactive Ion Beam Project." Oak Ridge, Tennelesee, October 7.10, 1992, CONF-9210121-5, p. 41, 1992 (NTSS Order No. DE930.06628). *

8. Hutton, A., "CEBAF Commissioning Statue," Proteeding of the 1993 Particle Accelerator Conference, Whehington, D.C., V5(3933), 1993 (IEEE Catalog Number 93CHa279-7) (ISBN 0-7803-1203-1).

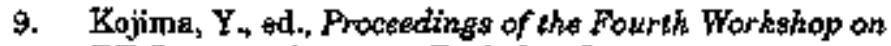
RF Stuperconductivity, Trukuba, Japan, Auguat 14-18, 1989, 2 Vols, KEK-89-21, KEK, January 1990 (NTIS Order No. DE90508149).*

10. Praceedings of the Fourth Intemational Conference on Ion Sources, Bensheim, Germany, September 30-October 4. 1991, Review of Scientific Instruments, Issue 4, Part 2, 6\$2351-2910, April 1992 (ISSN 0034-6748).

11. Procteding of the International Conference on Ion Sources, Reviow of Scientific Ingtruments, 61(1), Part II, Jantary 1990 (ISSN 0034-6748).

12. Prockedings of the 1990 Linear Accelerator Conference, Los Alamos National Laboratory, Abbuquerque, NM, September 9-14, 1990, LA-12004-C, 1991 (NTTS Order No. DE9100929B)*

18. Thiessen, H. A., "Towards an Advanced Hadron Facility at Los Alamos," Aceeterctor Design Workshop, Log Alamos, NM, Febrtatry 17, I98g, CONF-880263-4, Los Alamos Report No. 8B-1349, 1989 (NTIS Order No. DE86009117).

14. "Nuclear Physice Actelerator Factlities of the Warld," U.S. Depertment of Energy, Office of Energy Reenearch, Washington, D.C., Report No. DOEJER-058\%, December 1991 (NTIS Order No. DE92006873).*

\footnotetext{
* Se Section 7.1

** Available from Elagvier Seience Publiehing Co., Inc., P.O. Box 882, Madizon Square, New York, NY 10159
} 


\section{PLASMA CONFINEMENT SYSTEMS TECHNOLOGY}

DOE supports the operation of several different fusion plasma confinement devices as well as the design and development of future devices such as the International Thermonuclear Experimental Reactor and the Tokamak Physics Experiment. Bexause maryy common problems are encountered in these various devices, it is possible to identify specific technology areas where innovative research and development would benefit the entire fusion experimental program. All subsystems and technology proposed must be compatible with appropriate plasma conditions of temperature, radiation, stress, allowed impurity level, etc. Excluded from this topic is research pertaining to cold firsion, inertial confinement fusion, and other fusion energy concepts that are not based specifically on magnetic confinement of plasmas. Also excluded ars theoretical studies and computar code development unless specifically associated with and needed for the design and development of components. Grant applictations pertaining to technology development are invited only in the following gubtopics:

a. Radio Frequency Plasma Beating SystemsIn plasma heating, radio frequency (RF) heating is of particular interest. The relevant frequency ranges are 0,05 to $0.3,1$ to 6 , and 30 to $600 \mathrm{GHz}$, and the required power levels are 0.5 to $5 \mathrm{MW}$. Many RF sources and components are not available in this range of power levels and frequencies, especiglly those at millimeter wavelengths. Grant applications are sought to develog transmission lines, low-loss windows, circulators, loads, calorimeters, vacuum feed-throughs, electron guns, power supplies, magnet systems, launchiug structures, Faraday shields, and insulating coatings compatible with a plasma environment The application of concepts to solve special cooling problems of components is an example of possible innovative development,

In particuler, two RF heating methods chosen for near term and future large and mid-size fusion applications are Ion Cyclotron Resonance Hegting (ICRH) in the range of frequencies .05 to $0.3 \mathrm{GHz}$ and Electron Cyclotron Resonance Heating (ECRH) in the tange of frequencies 100 to 300 GHz. These systems are expected to operate at very high powers for long pulse lengths. Total system pewer of 10 to $50 \mathrm{MW}$ and pulse length from 30 seconds to continuous operation are under dísenssion. Grant applacations are songht for: (1) antenne syotems cepable of launching $5 \mathrm{MW}$ through a 1/4 square meter area port need to be developed (because of the limited number and size of access ports and the need to shield antenns components) and (2) other components of the system, many of which do not exist in the necessary parameter ranges, such as turing capacitors, feed-through devices, coaxial cable, stub toners, RF power ampliffers and tabes for ICRH, and zode corverters, windows, output couplers, loads, and launching systems for ECRH.

High voltage, high current power supplies to operate RF sources are also required in three typical operating ranges: 1 to $2 \mathrm{kV}$ at 10 to $100 \mathrm{kA}, 50$ to $100 \mathrm{kV}$ at 0.1 to $1 \mathrm{kA}$, and 500 to $2000 \mathrm{kV}$ at 10 to $20 \mathrm{~A}$. The required waveforms are frequently neither AC nor DC, bat rather follow a complex time histary. Response times of order $0.5 \mathrm{~ms}$ are needed. Grant applications are sought on innovative microprocessor controllers for thyrister power supplies, gate-turn-off thyristors that exceed present performance, fast acting safety devices for thyrístors, and fast-opening breaking switches that can interrupt hundreds of kilosmperes and withstend tens or hundreds of kilovalts. Switching power-supply technology appears ready for several of these applications that have heretofore used conventional transformer-rectifier systems.

b. Particle and Impurity Control-Desired particles are injected into the plasma by fueling, and undesired particles are removed by the vacuum generation process. Grant applications are sought to improve the performance and reliability of high velocity deuterium or tritium pellet injectors. Cast reductions compared to existing systems must be addressed. Grant applications are also sought for jmprovements to the following components of particle removal systems: high speed vacuum pumps and other hardware for continuous pamping as well as rapid evacuation of the chember berwsen pulses, seals designed to withstand masual thermal and/or electrical stresses, water cooled bushings for high power feed throughs, electrically conducting quick disconnects for vacuum application, remote leak detection systems, and improved ultra-high vacuum valves. The extraction of energy from energetic particles leaving a fusion plasme is also of interest.

c. Eigh Heat Flux Materials/Plasina Facing Components-This subtopic addresses plasma facing (non-structural) materials and components which must

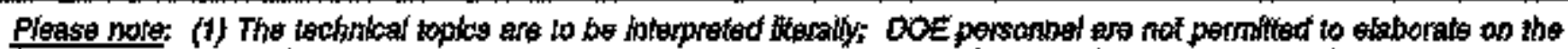

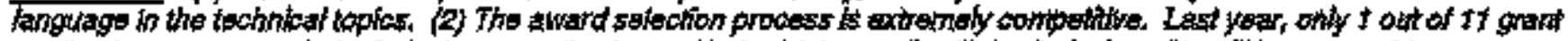

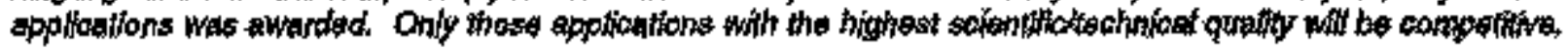


survive the large heat fluxes, plasma-induced erosion, and neutzon damage expocted in a fusion reactor. Surface heating conditions span the range of long pulse heat fluxes ( 0.1 to $\left.1 \mathrm{MW} / \mathrm{m}^{2}\right)$ on surface areas characteristic of first well heat rejection components, long pulse heat fluxes ( 1 to $10 \mathrm{MW} / \mathrm{m}^{2}$ ) on divertor components, and short pulse heat fluxes (10 to 500 $M W / \mathrm{m}^{2}$ ) on surfaces appropriate to plasme disruptions $\left(10^{3} \mathrm{sec}\right)$. Grant applications are sought for: (1) radiation resistant high thermal conductivity materials and techniques for the control of erosion and redeposition, for lizniters, divertors, wall armor, and liners; (2) heat dissipating materials and techniques; and (3) brazing techniques for graphites and carbon/carton composites and techniques for increasing thermal conductance at mechanical joints under high thermal loading (for braze joints, nos-destructive evaluation techniques must be addressed).

d. Superconducting Magnets and HaterialsThis subtopic addresses the design and development of new or advanced concept magnets for plasma fusion confinernent systems; $i, e_{n}$, high field magnets (12 to 16 T) and low loss pulse magnets for tokamak systems. Grant applications are sought for: (I) innovative and advanced materials and manufacturing processes that have a high potential for attractive conductor performance and low fabrication costs; (2) cryogenic superconductor materials with high crítical current density, low sensitivity to strain degradation effects, and radiation resistance; (3) novel, low cost cable design and fabrication techniques which minizinize conductor strain; (4) superconducting joints for high field and polse applications; (5) thick $(30 \mathrm{~cm})$ weldable structural case materials with high strength and toughness at $4 \mathrm{~K}$; (6) welding technigues for thick cryogenic structural materials; (7) radiation-resistant electrical insulators $\left(e+g_{+}\right.$wrapable inorganic insulators and low viscosity organic insulators); (B) nondestructive evaluation techniques for thick section steels and thick section weldments; and (9) low-cost, efficient, and reliable cryogenic support components (such so liquid helium pumps and cryogenic dewars).

\section{Bibliography}

1. Abdou, M. A, et al, 'Magnetic Fusion Energy Plamm Interactive and High Heat Flux Components. Volume II. Technical Asseasment of the Critical Isanes and Problem Areas in High Heet Flux Materials and
Component Development," Report No. UCLAPPG-816, Jub I984 (NTIS Order No. DE86001155)*

2. Adtanced Fustion Concepts Project Stmmaries: FY 1983, DOE/ER-0148/1, U.S. Department of Energy, Wabhington, D.C., June 1988 (NTIS Order No. DE88013978), "

3. Conn, R. W., et al, "Magnetic Fueion Energy Plaspa Interactjo and High Hoat Flux Cormponents. Volume I. Technicel Assessment of the Critical Irsuas and Probley Areas in the Planmia Matorials Interaction Field, " Report No. UCLAPPG-?65-Vol.1, January 1964 (NTIS Order No. DE84011527) *

4. Fusion Technology Development Plan", U.S. Depertment of Energy, Report No. DOE/ER-0166, May 1989 (NTIS Order No. DE93012954),"

5. "Future Engiseering Needs of Magnetic Fusion;" National Reeearch Counefl, Report No. DOE/ER/64008-T1, I9s2 (NTIS Drder No. DEg3004216).*

6. Mukhovatov, V., et al, IrER Diagnoetice, ITER Documentation Series, vol. as, Vienne, Austrí: LAEA, 1991 (NTIS Order No. DE91628549/XAB)."

7. National RF Technology Resersth and Development Program Plan, CONF-880758, Oak Ridge Nationel Laboratory, May 1983 (NTIS Order No. DE69011060)*

8. Plasma-Wall Interaction Data Needs Critical to a Burning Core Experiment (BCX); June 24.28, 1986; U.S. Departinent of Entergy, Luvermore, CA, Report on the U.S. Department of Energy-Japan Workehop Q-\$2, CONF-8508177.Vol 2, U.8. Department of Energy, Washington, D.C., 1985 (NTIS Order No. DE87013323.).*

9. Proceedings of the 2nd Meeting on Electrical Insulators for Fusion Magnets, September 8, 1982, U.S. Department of Energy. Germantown, MAD, CONF-820915s, Washington, D.C., July 1983 (NTIS Order No. DE6\$17540).*

10. Procedings of the 9th Topical Conference on High Temperature Plasma Diagnastics, Santa Fe, NM, March 15-19, 1992, Review of Scientific instrumente 68(10), October 1992 (ISBN 1-56996-109-1).

11. Proceedings of the 15th Sympooiutn on Fusion Enginesing, Hyannis, MGA, October 11 .15, 1993, 2 Vols., IEEE Service Center, Piecataway, NJ (LEEE Catalog No. 98CH3348-0) **

12. Special Purpose Materials for the Fusion Reactor Environment A Technical Assesement, U.S. Depertment of Energy, Washingtor, D.C. February 1978 (NTIS Ordar No. DOEET-0015)*

13. Stott, P. E, et al, edi., Diagnastics for Fuston Reactor Conditions, Procesdings of the Course and Workshop, Varenna, 6-17 September 1982, Elmaford, NY: Perrsamon Preso, Inc., 1984 (ISBN 0-08-031161-X).

14. Technicsl Planning Activity: Final Report, U.S. Department of Erergy, Argonne National Leboratory Report No. ANLFPP-87-1, Jantuary 1987 (NTIS Order No. DEs7004635/XAB),* 
15. Van Ingen, A. M., et al, Fusion Technology 1988: Procedings of the 16th Sympasium, Utrecht, The Notherlands, September 19-23, 1988, New York:

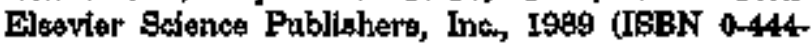
87869-4).

\author{
\% See Section 7.1 \\ ** Available from IEEE Bervice Center, 445 Hoes Lape, \\ Pietataway, NJ 08655 (Telephone 800-678-4893)
}

\section{FUSION ENERGY SYSTEMS}

Practical applications of magnetic fusion enersy in the next century will require the successful development of materials, nuclear technologies, and maintenance/repair approaches for safe, reliable, and environmentally attractive operation of fusion power systems. The longrange technical problems posed by these thallenges generate mony research opporturities. Excluded from this topic is research pertaining to cold fusion, inertial confinement fusion, and other fusion energy concepts that are not based specifically on magnetic carfinezuent of plasmas. Grant applications are invited only in the following subtopics:

a. Materialo-Grant applications are invited for research that will lead to relaxation of operating limits on materials for fusion applications in three specific materials systems. These are vanadium alloys and silicon carbide/silicon carbide ( $\mathrm{SiC} / \mathrm{BiC}$ ) composites for structural applications, and insulating ceramics for use in diagnostic or radio frequency power transmission components. All three materials require increased resistance to degradation under neutron irradiation. Additional limitations that could be addressed include relaxation of the protection requirements of vanadium alloys set by their sensitivity to the pick up of gaseous impuritjes, the limitations on BjC/SiC composites set by available production and jofining processes, and the limitations on insulating ceramics set by the sensitivity of electrical properties to ionizing and displacing radiation fields. Additional information on the limitations of these three materials classes can be found in references (3-8).

b. Fuglon Nuclear Technology-Grant applications are sought to develop concepts for a Volumetric Neutron Source (VNS) to test, develop, and qualify fusion nuclear technology components and materials combinations. VNS, as a possible strategic element of an agresssive fusion prostam leading to demonstration power plant (DEMO) operation by 2025, would operate in paralle] with the International Thermonuclear Experimental Reactor (ITFE) and the International Fusion Matersals Irradiation Factility to provide the nuclear technology data base for DEMO. VNS, which would scresn candidate DEMO nuelear component concepts, verify performance of promising concepts, and provide for engineering development and reliability growth of leading concepts, should be a plasma-based device operating in a plasma-driven mode with deuterium-tritium fuel. The features required of a VNS to aceomplish its mission include: (1) \& DEMOlike nuelear operating environment within tast spaces, (2) a plasma facing surface area for testing greater than $10 \mathrm{~m}^{2}$, (3) an average neutron wall load and heat flux on plasma-facing surfaces of test spaces greater than $1 \mathrm{MW} / \mathrm{m}^{2}$ and $20 \mathrm{~W} / \mathrm{cm}^{2}$, respectively, (4) steadystate or high duty-cycle pulsed operation with a minimum burn time of 1000 seconds and a maximum dwell time of 100 seconds, and (5) duty cycle $x$ availability greater than 8 , with a cumulative fluence potential of at least $6 \mathrm{MW}-\mathrm{yr} / \mathrm{m}^{2}$. Evaluation criteria for VNS attractiveness include* (1) capital cost, which should be ne more than 25\% of ITER's cost, (2) fusion power, which should be less than $300 \mathrm{MW},(3)$ use of proven tachnologies, (4) site electrical power consumption, which should be less than $500 \mathrm{MW}$, (5) the ability to rapidly install and replace test brticles, and (6) the ability to rapidly replace any failed device componant. Grant applicetions must demanstrate that any planned concept for VNS will meet all the above feature requirements and must determine the extent to which the proposed concept satifites the above evaluation criteria. Proposed VNS concepts must emphasize the potential for low capital cost, low fusion power, minimal use of unproven tenhnology, low electricity consumption, and low installation/replacement/repair times.

\section{Bibliography}

1. Ahdou, M. A. et al, "Etudy of the Itesues and Experiments for Fusion Nuclear Tochnology," Fusion Teclinalogy, V8:N3(2595-2645), 1985 (ISSN 0748-1896),

2. Abdou, M. A, ot el, "Trectuical Isoues and Requirements of Experiments and Facilitie for Pusion Nuclear Tochnology," Nucloar Fueiom, V27:N4(619-689), 1987 (ISSN 0029-5515).

3. Clinard, F. W., Jr, at al, "Materiala Iesues in Diagnostic Systema for BYX and ITER," International Conference on Fusian Reactar Mfalerials (JCFRM-6), Clearuater,

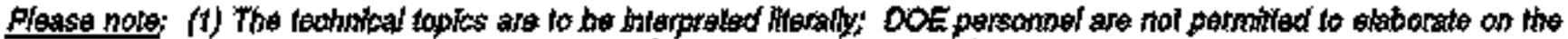


FL. November 17.22, 1991, Journal of Nuclear Materials, V181-194:Pt.B(1899-1408), September 1992, CONF-911111 (ISSN 0022-8155).

4. Harties, D. R, et al, -Evaluation of Reduced-Activation Options for Fudion Materlals Development, Fifh International Conference on Fusion Retuctor Materials, Clenruater, $F L$, Nouember 17-22, 1991, Journal of Nuclear Materials, V191-194:PartA(92-98), Septeaber 1992, CONF-911111 (ISSN 0022-3115).

5. Jones, R. H., ot al, Compoeito Matorialo for Fusion Applications," Fifh International Conference on Fuston Renctor Materials, Clenrubder, FL, Nowember 17.22, 1991. Journal of Nuclear Materiale V191-194:PartA(7583), September 1992, CONF-911111 (IsSN 0022-3115).

6. Loomis, B. A., "Vandium Alloys for Structural Applications in Fusion Systoms: A Review of Vandium Alloy Mechanical and Physical Properties," Fifh International Confenence on Furion Reactor Afaterials, Cleartuater, FL, Noumber 17-22, 1991, Joumal of Nuckear Materiale, V191-194:PartA(84-91), September 1992, CONF-911111 (ISSN 002Z-3115).

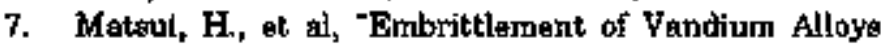
Doped with Helium,- Fifh International Conference on Fusion Reaction Materials, Clearustar, FL, Nowember 17.22, 1991, Journel of Nuclear Materials, V191194+PartBr919-908), September 1992 (ISSN 0022-3115).

8. Zinkle, S. J., and E. R. Hodgson, "Rediation-Induced Changes in the Phyrical Properties of Ceramic Materials," International Confersncs on Pusion Reoctor Materials (1CFRM-5), Clearuater, $B L$, November 17-22, I99I. V191-194:Pt.A(58-66), Journal of Nuclear Materials, September 1992, CONF-811111 (ISSN 0022 3155).

\section{PLASMA DIAGNOSTICS}

DOE is eurrently supporting several magnetic fission related plasma experiments that require diagnostics for measurement of plasma parameters and analysis of plasma observations. Two new magnetic fusion devices are now in the design stage-the large International Thermonuclear Experimental Reactor and the advanced, long-pulse Tokamak Physics Experiment. The goals of this topic are to develop and demonstrate novel techniques and instrumentation that provide reliable, multidimensional spatial end temporal resolution for critical plasma parameters; to make previously proven technjques more avajlable under new plasma conditions; and to provide components and systems to improve diagnostic reliability. Improvemenis to accommodate the access restrictions and long pulse ( $\geq 1000$ seconds) requirements of the next step tokamaks are needed.
Areas of interest to DOE under this topic include complete diagnostic systems for measuring plasma parameters, individual components of these systems, improved performance of currently used systems, and improved capability for data analysis. Excluded from this topic are concepts and systems pertgining mainly to inertially confined plasmas which should be submitted under topic 22. Innovative grant applica. tions are invited only in the following subtopics:

a. Plasma Parameter Measurement-Major parameters to be measured include plasma density, electron and ion temperature, plasma current and plasma current density, plasma position and shape, plasma jmplarity density, magretic field strength, ambipolar potentia]s, and radiation from the plasma. These parameters require both good spatial and temporal resolution. Real time measurements of some plasma parameters, such as plasma position and shape and plasma current density, will be needed for active control of long-pulse plasmas. In addition, methods are desired for examining the edge plasma region and areas of bigh heat flux deposition on limiters or divertor plates. Finally, measurement of the properties of auxiliary plasma heating and non-inductive current drive is also desired. Grant applftcations are sought to develop techniques for measuring these parameters. Not only must absolute values be measured, but also smal] relative differences in those values in space and time. Instrumentation must be capable of a large dynamic range and be senșitive to small variations.

b. Partiele Detection and Detector SystemgGrant applications are solitcited for: (1) detecting and characterizing particles from RF heating including ions, electrons, neutrons, and photons; particles injected by neutral beams; and confined and escaping charged fusion products of deuterium-deuterium and deuterium-tritium fusion reactions; and (2) determining the energy spectra, spatial distribution, and time evolution of thermalized plasma particles, including impurities for which the charge state is also significant.

With regard to detector systems, grant applications ate sought to develop: (1) improvements to increase accuracy end resolution of detector systems (e.g., increasing the signal-to-noise ratio in ingtrumentation or extending the range over which measurements can be made); (2) sources and calibration techniques in the microwave and far infrared regions for improvement of electron cyclotron emisssion, scattering, reflectometry, 
prad interferometry methods; (3) improvements to infrared surface temperature measurement techniques for fast time response and magnetic field compatibility; and (4) calibration techniques for neutron measurement systems with a very wide dynamie range.

c. Components for Special Environments-With the advent of tokamak operation with burning plasmas, there is a significant requirement for radiation hardened components. Grant applications are sought for hardware (such as vacuum components, optical components, fiber optics, and detectors) that ean be used in a harsh fugion enviromment characterized by high vacuum, high radiation, high temperature, and high magretic field. The environment may also include the soft $x$-ray and vacuom ultraviolet spectral ranges. Survivability, capability for calibration, and potential for handling by remote maintenence equipment should be considered. For spectroseopic devices, improvements in diffracting elements, gratings, spectrometers, windows, and monochromators are needed to ensure radiation resistance and ruggedness.

Grant applications are also saught to improve the resistance of diagnogtic components such as fast gauges, costings, probes, encoders, gratings, and windows to ultra-high vacuum environments ( $10^{\mathrm{a}}$ torr) with their attendant magnetic and electric fields, temperatures, and vacuum. High reliability feedthrough tachniques between vacuum and air are necessary, such as those for fiber optics and for transmitting hinear or rotary motion. Surface treatment, repair techniques, and in-situ calibration tachniques are needed.

d. Data Analysis and Processing-Data from tokamak diaenosties will increasingly be nsed for realtime control of the plasma. Grant applications are solicited for innovative algorithms and systems to speed up the data reduction process (i.e. the conversion of raw data into signals representing control variables and the determination of control commands from these signals).

\section{Bibliogxaphy}

1. Abdou, M. A, et al, "Magnetic Fusion Finergy Plasma Interactlve and HIgh Heat Fluy Components. Volume II. Texhnicel Astegespent of the Critteal Istuet and Problem Areas in Fligh Heat Flux Materials and
Component Develipment," Report No. UGLAPPG-815, June 19a4 (NTIS OTder No. DE85001165.),*

2. Conn, R. W, te al, "Magnotic Fusion Energy Plakrma Interactive and High Heat Flux Components. Volume I. Technical Angengement of the Critical Issues and Problem Areas in the Plasma Materials Intaraction Field," Rapart No. UCLA/PPG-76\%.Vol+1, January 1984 (NTIS Order No. DER4011827)**

8. "Fution Enginearing Device Votume V. Technology R\&D Requirements for Constrastion," Report No. DOETTIC-1160o(Vol.5), Ottober 1981 (NTIS Ordor No. DE92008966)**

4. Hutchingon, I. H., Principles of Plasme Diagnogtica, Cambricgs, MA: Cambridge University Pregs, 1990 (ISBN 0.521-38598-0).

5. Lubell, M. S., et al, Procedings of the 12th Symporim on Fuston Engineering, CONF.87007., LEEE Service Center, Piacataway, NJ, 1987 (NTIS Order No. AC05. 85OR21400)."

6. Luhpann, N. C. and W. A. Peebles, "Instrumentation of Magneticelly Confined Fueion Plasma Diagnoetice," Boview of Scientific Instruments 56(3):279-381, March 1984 (ISSN 0084-6748).

7. Miyahara, $A_{\text {n }}$ and $K \mathrm{~L}_{+}$Wilson, In Proceedings of the Japan-U.S. Workshop P.92 on Plasmo Material Interaction/High Heat Fluz Data Needs for the Next Step Ignition and Sleardy State Devicat, $26-30$ Januaty 1097, Irotitute of Plasma Physics, Nagoya, Japan, CONF-870185 (NTIS Order No, DE87018568XAB)."

8. Mukchovatov, $V_{4}$ at al, IMFER Digknostics, ITER Doetumentation Serjes, Yol. 38 , Vienne, Austrie: LAEA, 1991 (NTIS Order No. DE91628549/XAB).*

9. Froceddings of the 9th Topical Conference on High Temperature Plasma Diagnastics, Sonta Fo, NM, March 15-19, 1992, Review of Scientific Instrumente, 63(10), October 1992 (ISBN 1-56396-109-1).

10. Proceedings of the 13th Symposium on Furion Engineering, Knoxuille, TN, October 2-6, 1989, 2 Vola. I No. CHEg20-9)**

11. Stott, P. E., et al, ada, Dicgnostics for Pusion Peretor Conditions, Procedings of the Course and Workshop, Varenna, 6-17 September 1882, Elmeford, NY: Pergemon Press, Inc., 1984 (IBBN 0-08-081261.X).

12. U.S. Department of Bnergy, Futsion Tecknology Development Plan, Report No. DOE/ER-0166, Mey 1983 (NTIS Order No. DE88012954).*

13. Plama-Wall Interaction Data Needs Critical to a Burning Care Experiment (BCX); 24-28 June 1985; Livermore, CA Report on the U.S. Depertment of Energy Japan Workshop Q-32, CONF-8506177-vol 2, U.S. Department of Energy, Washington, D.C., 1986 (NTIS Order No. DEA7013323).*

14. Ven Ingen, A. M., et al, Fusion Technology 1988: Proceadings of the 16th Symposium, Utrecht, The Netherlands, 19-23 September 1988, New York: 
Elsever Scfence Publishers, Inc., 1989 (ISBN 0.444. B7369-4).

15. Woekov, P. P., "Proceedings of the 8th Topical Conference on High Temperature Plasma Diagnostics; 6.10 May 1990; Hyarmis, MA, " Review of Scientific Ingtruments, 61(10), part 242733-3316, October 1990, CONF-90057 (ISSN 0034-6748).

\footnotetext{
* See Section 7.1

** Available from IFEe Service Center, 446 Hobs Lane, Plscataway, NJ 08855 (Telephons B00-678-4333)
}

\section{TECHNOLOGY AND INSTRUMENTATION FOR HEAVY ION FUSION ACCELERATORS}

Through its programs in Heavy Ion Fusion Accelerator Research, DOE supports a broad research and development effort in the science, engineering, and technology of heavy ion accelerators and associated apparatus. Advanced R\&D is needed in support of this program in the following areas: (1) new concepts for acceleration and novel device development, that witl contribute to overall advances in accelerator technology applicable specifically in the Heavy Ion Fusion Accelerator Research program, (2) charged particle beam instrumentation, (3) beam transport techriquues, (4) high current ion sources, and (5) low-cost vacuum insulating materials. Relevance to applications in heavy ion fusion research must be explicitly described and will be a factor in selection. Advanced RAD more gppropriate to high energy physics and not specifically to heavy ion fusion accelerators will not be considered reponsive and should be submitted nnder Topic 15. Grant applications are invited only in the following stabtopics:

a. Advanced Heavy Ion Accelerator ConceptsGrant applications are sought for advanced linear induction accelerator technology capable of providing kiloampere ion beams with 1 to $2 \mathrm{kA}$ of pulsed power at 1 to $2 \mathrm{MV}$ at repetition rates from a few $\mathrm{Hz}$ to 200 $\mathrm{kHz}$, including the use of multiple beams in a single unit. Of particular interest are pulsed power systems based on fast, high current, solid state switching suitable for accurate, programmable pulse shaping, and oconortical high voltage energy storage systems. These systems shouid include pulse waveform diagnosties with speed and accuracy comparable to the waveform generators.

b. Beam Transport and Control-Grant applications are sought for: (1) cost-effective devices that use electromagnetic, electrostatic, or plasma techniques to manipulate high intensity, high momentom, heavy ion beams; (2) methods for calculating the trensport of high energy ( 1 to $10 \mathrm{GeV}$ ), heavy (100 to $200+A M U$ ), short pulse (10 to $20 \mathrm{~ns}$ ), high current (1 to $10 \mathrm{Ka}$ ) jon beams to focal points $(<0.5 \mathrm{~cm}$ diameter) at a distance of about 5 meters from the final focus element under a renge (0.0001 to 10 torr) of reactor chamber vacuum conditions; (3) advanced particle beam diagnostic concepts and devices that provide high speed computer-compatible measurements of particle beam intensity, position, emittance, Juminosity, momentum, time of arrival, and energy; and (4) novel, effective techniquis to measure the transverse or longitudinal charge distribution in small radius ( $<5$ mon diameter), high carrent ion beams. Techniques proposed rnust be nondestruetive to the beams being monitored and be less costly than currently ased techniques.

c. Ion Sources-Grant applications are sought on particle beam jon sourtes that have improved intensity, emittance, range of species, and modest $\left(1^{+}\right.$to $\left.3^{+}\right)$ charge state. In particular, sources for induction linacs are sought, which may be laser driven and which have high current, modest $(-10 \mathrm{~Hz})$ repetition rate, and 1 to 20 us pulse lengths.

d. Materials-Grant appliegtions are sought for lowcost insulating riaterials for high voltage accelerating columns greater than 20 inches inside diameter which ars capable of having electrodes embedded during the manufactioning process and which also have low outgassing to maintain vacuums less than $10^{-8}$ torr. These insulators are needed for high voltage hold-off applications in injectors and accelerator modules.

\section{Bibliography}

1. Abakbian, A, ed. "Particles and Fieldg," In AIP Conference Procsedings No. 112, Blacksburg, VA, September 15, 1983, CONF-8309196 (OSTI Order No. TH84008600)."

2. Bangerter, R., et al, edB., Proceedings of the International Synzosium on Heary Ion Inertial Fusion, Konterey, CA, December 3-6, 1990, Particle Accelerators 37-38, 
Philade]phia: Gorkion and Breach Academic Pabliahers, 1992 (ISSN 0031.2460).

g. "Beam Interactions with Materials and Atoms," Nuclear Instruments and Mathods in Physics Regararch B29(3);447-690, 1987 (NTIS Order No. TT88018520).**

4. Bennett, F. and J. Kopta, eds, Proceedings of the 1989 IBEE Particle Actelerator Confenence Accelerator Sxience and Technology, Maroh 20-29, 1999, Chilego, IL, Vol 8 (IEEE Catalog No. agCH2669-0)* * *

6. Dugzan, J. L. and I. L. Morgon, eds. "Application of Accelerstors in Research and Induetry 1988," Pro. ceedings of the Tenth International Conference on the Application of Acosteralors in Restarth and Indtastry, Denton, TX, November 7-8, 1988, Parti I and 2, Nuclaar Instroments and Methode in Phygica Reaearch Yole. B40 and B41, June 1989 (ISSN 0168-588X/99).

6. Rurapean Particle Accelentior Conference; 7.1I June 1988; Rome, Italy, 2 Vole, June 1989 (NTIS Order No. DE99003967/XAB), *\#

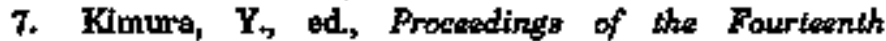
International Confenence on High Enery Accelerators, Augusit 22-26, 1889, Tsakuba, Japan, Particle Acealeretare 27:(1-4), New York: Gordon and Breach/Harwood Acedemic Publishers, 1990 (ISSN 00s1-2430).

8. Miley, G, ed, Puston Technolozy, 13:2(189-396), ANA, Februtary 1983 (TSSN 0748-1896).****

9. Milla, F. E., ed., "Advanced Accolerator Concepts," In AIP Conference Proceedings No. 156" Aduanced Accelerator Concepte Conference, Modison, WI, Auguet 21, 1986, New York: American Institute of Physics, 1987.†

10. Procsedings of the IBEE Partiole Acceterator Conference, 1991 (ISEN 0-7808-0136-6; 0-7809-0195-8; 0-7808-01874) (IEEE Catalog No. 91CH9088-7).***

11. Procesdings of the International Symposium on Heavy Ion Ingrtial Fugion, Frascati, Italy, May 25-26, 1993." Il Nuovo Cimento 106A \#11, V106A(2)(11), Norember 1998.

12. Rejger, M, et al, eds, Hearoy Ion Inertial Pusion: APP Conference Procedings, Vol. 152, Now York: American Ingtitute of Phyleie, 1986.t

13. Rostaker, N., et al, Proceedings of the Third International Conference on Collective Methods of Acceleration. Laguta Beach, CA, May 22-26, 1978, New York: Gordon and Brach Academic Publishart, 1979 (ISBN 3.17860005-6).

\footnotetext{
* Bee Section 7.2

** See Section 7.1

*** Available trom tha IEEE Service Canter, 445 Hoes Larr, Piecataway, NJ 08854 (Telephone 800-678-489a)

**** Ayatlable from the ANS Headquarters, 555 North Kensington Avenue, La Grange Perk, II 60525

† Avajlable from American Institute of Phystcs, care of: American International Distribertion Corp 64 DEPO Road, Colcheater, WT 05446 (Talephone 800-488-2665)
}

\section{COST-EFFECTVE METHODS FOR COATING POLYMERS}

Replacement of metal automobile components with lighter-wejght parts formed from structural polymers has contributed to substantially decreased fuel consumption over the past few decades. Other advantages of stmuctural polymers include increased toughness, improved aqueous corrosion resistance, and net-shape formability. Methods developed to apply scratch-, UV-, or alcohol-resistant coatings to polymors (such as vacuum deposition, evaporation, sputtering, and chemical vapar deposition) tend to bo expensive due to high capital equipment costs and/or low application rates. Also, complex shapes are difficult to coat with existing technologies. Development of more cost-effective coating methods, such as solution-based techniques for dipping or spraying, could lead to wider application of structural polymers in automobiles as well as in many other products. These coatings can be either previously known or innovative and can be comprised of single or mutliple layers. In any case, the coating system must be expected to meet performance criteria appropriate for the proposed end-use application. Grant applfcations are invited only in the following subtopfes:

a. Application of Seratch-Resistant and UV. Resigtant Transparent Coatings-The replacement of glass by structural polymers is restricted due to lack of surface bardness and to deterioration caused by exposure to the ultraviolet (UV) pertion of sunlight. Grant applications are invited for the development of a cost-effective protess to apply seratch-resistant, optically transparent coatings to flat or moderately curved surfaces of acrylic or polycarbonate components. The system should also incorporate a UV blocker, whether it is included in the scratch-resistant coating, or in an intermediate coating. The final properties of the coated product should be conststent with tits ase as automotjve windows or windshields. Projects should be designed so that they culminate in the development of industrial-scale equipment and processes for the casteffective coating of polymer components.

b. Application of Seratch-Resistant Coatings to Complex Shapes-Many automotive components, which gre not as gently curved as windshields, may have irtegular shaped geometrics (including holes, sharp bends, and corners). Grant applications are

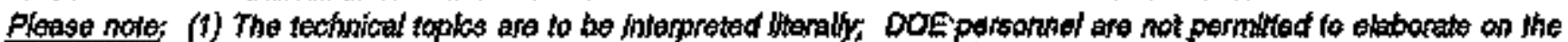

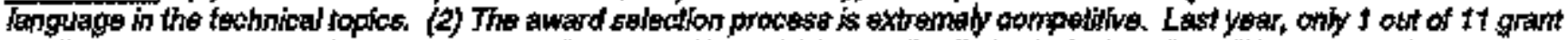

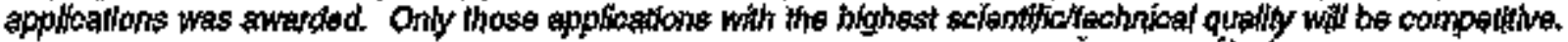


invited for the development of a cost-effective process to apply scratch-resistant coatings to complex-shaped polymer components. Projects should be designed so that they culminate in the development of industrialscale equiptrent and processes for the cost-effective coating of polymet components.

c. Application of Alcohol-Resistant Coating gem The use of polymers to replace metallic components that come in contact with (alternative) fuels is restricted due to chemical degradation by alcohol. Grant applications are invited for the development of a cost-effective pracess to apply coatings, resistant to autamotive fuels containing several percent of methanol or ethanol, to complex-shaped polymer components. Projects should be designed so that they culminate in the development of industrial-scale equipment and processes for the cost-effective coating of polymer components.

\section{Bibliography}

1. Bucken, B., et al, "Manufacture and Properties of Transparent Protective Layara Produced by Vacuum Technologies, Proceedings of the Seventh International Conference on Vactum Web Cating, Miami, FL, November 10.12, 1993, pp. 227-292 (ISBN 0-939997-15-0).

2. Chambers, D. L., et al, "sputtered Coatings for Polymeric Composites," Proceedings of the 32nd Annutal Technical Conference, Society of Vactum Coaters, St. Louis, MO, 1989, pp. 290-296 (ISSN 0731-1699).

3. Masao, J. D., "Evaluation of Scratch Resistant and Antireflecting Costings for Plastic Lenges," Frockedings of the 32nd Annual Technical Conference, Saciety of Vaculum Coaters, St. Louis, M4O, 1989, pp. 237-240, 1989 (ISSN 0731-1699).

4. Misana, C., et al, "New Perspectives in A1208 Based Transparent Oxide Barriar Coatinga," Proceedings of the Seventh International Conference on Vacuum Web Coat. ing, Miami, FL, November 10.I2, 1993, PP. 220-227 (ISRN 0-939997-15-0).

5. Nasgel, W. Production PropertioB, Processing, and Applications of Slo-Coated Filme," Proceddings of the Sesenth International Conference on Vocu un Web Cont. ing Miami, $F L_{1}$ Nouember 10.12, 1998, pp. 258-267 (ISBN 0-939997-15-0).

6. Schiller, S., et at, "How to Produce AL Coatinge on Plantic Films," Proceedings of the Seventh International Confenence on Vactum Web Coating, Mtami, $H_{2}$, Novem. ber 10-12, 1993, pp. 194-219 (ISBN 0-989997-15-0).

7. Strupinaky, G., Transparent Barrier Materislg for Packsging," Proceedings of the Beventh International
Conference on Vacutum Web Corting, Micmi, FL, November 10-12, 1989, pp, 277-292 (ISBN 0-939997-15-0).

\section{RESEARCH ON THE ELECTRONIC EXCHANGE OF SCIENTIFIC AND TECHNICAL INFOAMATION AMONG ORGANIZATIONS}

In 1990, DOE received legislative authority to use its resources to enhance mathematies and science education. Largely through the national laboratories, DOE developed and implemented a number of outreach programs that are recognized both for tbeir quality and unique scientific expertise and resources. However, because of technological barriers to nationwide implementation, these prograns have had primarily local impact. An architecture which makes educational outreach programs accessible nationwide is a necessary Boal.

New standards and technologies emerging today allow DOE to take a much needed corporate approach toward accessing and integrating educationel program resources in ways not previously imagined Recently, DOE has adopted ISO Standard 8879, Standard Generalized Markup Language (SGML), as the standard for exchange of full text scientific and technical information. SGML handles full text, as well as moltinedia, an integral aspect of information developed for students and teachers. A nonproprietary architecture for capturing information electronjcally as well as for facilitating easy access and exchange of full text math and science documents and multimedia is essential in the future.

DOE intends to capitalize on standards, information technologies, and expertize to link its education materials programs through long distance learning system to student and teacher populations in aupport of the Nation's future scientific and technical needs. In so doing, the need for well-educated, highly skilled scientific and technical persormel to carry out the DOE's besic research and development and operational missions will be addressed. Grant applications are invited only in the following subtopics:

a. Collaborative Writing and Editing of Scientifie and Educational Materials-Authoring and 
editing of educational documents and multimedia output (e.g., Eraphics, pictures, voice) can occur in groups within sites, among groups within sites, and among organizations. This collaborative writing and editing process is currently cumbersome, tontimely, and cost ineffective particularly in organizations which have related, but, geographically dispersed sites. Grgnt applications are sought for developing a wide-areanetwork for collaborative writing and editing of scientific and technical education documents within and among geographically dispersed organizations. The network should include the use of ISO Standard 8679, SGML. It should reflect where and how the markup should occur and depict the use of SGML encoding in a simple, non-offending manner, particularly to the originating guthor(s), The network should be designed to: (1) demonstrate a wide-area-network pilat between the DOE Office of Scientific and Technical Information and at least three dispersed DOE contractor and educational sites, and (2) maximize access and utility by sterdents meeting educational requirements for technical careers, and post-college occupational opportunities. Applicants are expected to be thoroughly familiar with the SGML and knowledgeable of the current state-of-the-art of methods and procedures for writing, editing, and electronic and multimedia publishing. A general knowledge and understanding of unath and science education programs within the United States is expected as well.

b. Blectronie Exchange Architecture-The exchange of electronically created full text sejentific and technical edueational documents and multimedia (e.g., graphjes, pictures, voice) within and among orgenizations is currently very difficult or impossible. This situation results from the use of multiple types of electrontc files, proprietary systems, mixed hardware and software platforms, etc. Grant applications are sought to develop an organization-wide, full text, electronic exchange architecture applicable for use by widely dispersed DOE sites, DOE contractors, and educational organizations. The arehitecture should include the use of the ISO 8879 SGML as the eneoding standard for making the full text and multimedia data neutral and transferrable over time and across multiple organizations with mixed platforms. The electronic architecturgl exchange should reflect eleetronic exchange requirements for implementation both within and among at least ten multiple and geographically dispersed government, contractor, and educational sites. A description of required standards, technologies, organizational requirements; and related costs for implementing the architecture should be included with the design in the grant application.

\section{Bibliography}

1. Bryen, Martin, "An Author's Guide to the Standerd Generalized Markup Lenguage," Addtson-Wesley, 1980 (ISBN 0-201-17595-5).

2. "Education Programe Catalag," US. Department of Energy, Weshington, D.C., 1994, Repart No. DOELT+ 0006T (NTIS Order No. DE94001295).*

3. Goldfarb, Charles F, The BGML Handbook, 550 Pp., 1091 (ISBN 0-19-853737-9).

4. Grudin, Jonathen, "Cocuputer-Supported Cacperative Work: Higtory and Focus," COMPUTER, V275(19), Cover Story, May 1994.

5. Schettinl, Stephen and Liora Alscherler, SGoph Ie Hare To Stray, (Tutorial) V9:NG(71), June 1994

6. Van Herwijnen, Eric, Practical BQMML, 2nd ed., Kluwer Academic Publishere, 812 pp., 1994 (ISBN 0-7923-9434 b).

\footnotetext{
* Bẹs Bection 7.1
}

\section{ELEMENTAL TRITIUM COLLECTION TECHNOLOGY}

DOE has facilities that produce and use tritium. Tritium processes are typically contained in negative pressure, inert atmosphere glovebores, and other confinement systems designed to prevent releases into the work room or the environment. These tritium confinement systems use oxidation of elemental tritium to form tritiated water to capture and store the tritium from the exhaust stream on molecular sieves. This creates occupationa] and environmental health risks because the oxide is 25,000 times more radiolocically hazardous than elemental tritjum. The tritiated water must then be further processed to convert it back to the elemental form creating additional potential hazards.

The cessation of nuclear weapons production operations has resulted in large amounts of tritium on molecular sieves that require processing or recovery as a part of decontamination and decommissioning activities. Recent reseerch has provided the theoretical background and materials to collect tritium from exhanst streams in its elemental form. This creates an opportunity for research and development on the 
design, fabrication, and tosting of metal hydride "getters" in pracess glovebox structures. If successful, the employment of this new getter glovebox cleanup technology at tritium facilities across the DOE complex would result in lower worker occupational dose, lower worker and public accidental dose, lower routine public exposure, and less production of waste. Additionally, a mare tightly controlled glovebox atmosphere and an increase in productivity will result. The Department's goal is to make the DOE nuclear complex safer and also provide an excellent product for transfer to the private sector. Grant applications are invited only in the following subtopice:

a. Metal Hydride Tritium Collection DevicesGrant applications are sought for development of metal hydride elementil tritium collection devices for cleening the exhaust gas from process gloveboxes. Phase I should include the fabrication of a prototype device and the conduct of experiments to describe specific performance data on the "getter" bed air cleaning system. Grant applications should describe capabilities to develop fully functional systems in Phase II.

b. Recovery of Tritium from spent Molecular Sieves-Grant applications are sought for the applieg. tion of metal hydride collection devices to the recovery of tritium from spent molecular sieves. Phase I should include the fabrication of a prototype device and the conduct of experiments to investigate specific performsnce data on the "getter" bed molecular sieve unloading system. Performance of this system should be evalueted under realistic flow and impurity concentration conditions. Grant applications should describe capabilities to develop fully functional systems in Phase II.

\section{Bibliography}

1. Baker, J. D., et al, Trytium Puriflcation Via ZirconiumManganeae-Iron Alloy Gettor St 909 in Flow Procesees," Journal of Vacmum Science and Tochnology, $12(2) \div 548$ 658, March 1994 (ISSN 0784-2101).

2. Baker, J. D. et al, "Tritiun Monitar and Collection Sygtem," U.S. Depertment of Energy, p. 10. March 26, 1991 (NTIS Order No. DE93002833)*

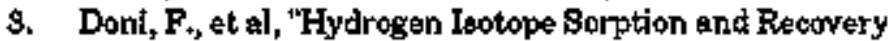
by a Nonevaparable Getter Combined with a Chemical Compressor Material," Journal of Vacuum Sclence and Technolory, A42447-61, 1986 (IBSN 0784-2101).
4. Bhmayds, W.T., at al, "Inert Gea Secondary Encloeure Clean-Up Systam," Eusion Tachnology, 21:616-21, 1902 (ISSN 0272-3921).

5. Shmayda, W.T., et al, "St 787 for Tritium Service: An Experimentel Evaluation" Fusion Technology 21:1024. 29, 1992 (ISSN 0272-3921).

B. Tamm, U., \&t al, "Uranium Getters for Tritium Cleanup at the Tritium Laboratory Karlaruhe (TLK)" Fuejon Techmology, 21:983-87, 1902 (198N 0272-3921).

7. Willen, E., et al, "Metal Gettere for Tritiun Storige' Furion Tzehnologk, 14:756-68, 1989 (ISSN 0272-9921).

See Section 7.1.

\section{TECHNOLOGY FOR SPACE NUCLEAR PROPULSION AND POWER}

DOE supports research and development on technologies for the application of radioisotope and reactor enercy to space missions of ather agencies of the U.S. government. Potential mission requirements (References 1-11) are for spacecraft electrical power for deep space exploration missions, electrical power for communication and sensing satellites, electrical power for lunar and planet surface exploration and space resources processing and utilization, and noclear propulsion for general use in space. The harsh environment of space and planetary atmospheres affects the utility of these systems, and ground testing requires special provisions, particularly for environmental and nuclear safety concerns. Thermal power levels are from half a watt to several thousand megrugtts. Advanced concepts, fuels, power canversion, and materials will be required. Significant reductions in mass, increased efficiency, and increases in temperature, lifetime, and reliability are needed. Grant applications are invited only in the following subtopicss

a. Reactor Power Systems-Reactors can be used directly to provide heat energy for nuclear thermal propulsion (NTP) or indirectly, through static or dynamic conversion, to provide electric power for many space uses, including nuclear electric propulsion (NEP). For space reactor power systems and NEP, the specific mass ( $k \mathrm{~g} / \mathrm{k} W_{\theta}$ ) and lifetimes of aystems and compo. nents are key drivers (References 6, 8, and 11). For NT'P, the specific impulse, with higher system temperatures, is the key driver, but mass is also of concern 
(References 4, 5, 7, and 8). Grant applications are invited for concepts or technology development that achieve significant inprovements in the key drivers for the above space reactor systems. Advances in the tollowing areas are of particular intorest: (1) innovative reactor and power system eoncepts including reactor and non-nuclear power systems combinations, reactor fuels, reactor materials and coatings, and reactor or auxiliary components, and (2) innovative and cost effective approaches in safety, safety systems and instrumentation, space nuclear test ground facifities, and eftuent treatment systems (References 2, 7,8, and 11). Nuclear concepts which combine NTP and NEP capabilities, inclading the option to provide electrical power, are sometimes descrihed as bimodal systems and are also appropriate for consideration (Reference 11). Grant applications must show that proposed concept and technology advances will lead to signtficant improvements in the key drivers and mission capabilities for future space reactor power systems.

b. Power Converston Bystems-Grant applications are sought for innovative and/or advanced power conversion systems and components, suitable for use within space reactor electrical power systems, including improvements in materials, manufacturing technigues, efficiencies, lifetimes, and costs. Of particular interest are advances in thermoelectric, thermionic, and other static gystems; dynamic systems; and advanced fuel cells coupled with static or dynamic systems, For thermoslectric conversion, an increase in device efticieney of at least $20 \%$ is sought for state-ofthe-art type silicon-germanium or other thermoelectric couples, and improvements leading to an increased figure-of-merit, $Z$, in type $p-n$ junctions for high temperature use are also of juterest. For thermionic conversion, research interests include improved high temperature emitters, contrainment alloys, and other meterials needed in thermionics. Other static and dynamic enexgy conversion concepts and technologies (including alphr and beta voltaic converters, AMTEC and HYTECH devices, advanced Brayton and Rankine dynamic systems, and hybrid systems for propulsion and power) that substantially imptove system efficiencies and/or lifetimes will also be considered. Grant applieations are also invited on improvements in heat transport and heat rejection because they are the key technologies which can be applied in the search for smaller systems. c. Isotope Power Systems-Radioisotope Power Systems (RPS) employing thermoelectric conversion have been the sole spacacraft electric power source for deep space exploration and have been used in the moon and Mars surface missions (References 9 and 11). While thermoelectric RPS power systems have been extremely reliable with operational lives in excess of 12 years, the system efficiencies for these thermoelectric systems are low (typically 6.5 to $9 \%$ ). For static systems, targeted conversion fficiency $216 \%$ in power ranges of 40 to 150 watt electriteal is desired. For dynamic systems, the target is $\geq 25 \%$ in power ranges of $60 \mathrm{~W}$ to $5 \mathrm{~kW}$ electrical. Grant applications are sought for attaining or approaching these target converston efficiencies in isotope power systoms with mission lives in the range of 10 to 25 years. Approaches should employ conversion based on one of the following technologies: a new thermolectric material and device, a thermo-photovoltaic systam, or a dynamic Stirling system. In addition, an innovative device employing segmented thermoelectric legs comprised of silicon germanium/lead telluride for equivalent) with a cold junction temperature from $\mathbf{5 0}$ to $250^{\circ} \mathrm{C}$ and hot junction of $1000^{\circ} \mathrm{C}$ is of interest. All thermal systems and materials must be compatible with a heat source based on the Genera] Purpose Feat Sodrce module (Reference 10). The maximum heat sotrce steady state temperature is approximately $1330^{\circ} \mathrm{C}$ for the fuel clad surface, which for a vacuum system yields a module surface temperature of approximately $1100^{\circ} \mathrm{C}$.

Grant applications are also invited on small isotope power sources with power levels in the 0.04 to 10 watt electrical range employing 238-plutonium dioxide or other isotopes and unigue static conversion systems. Emphasis should be focused on bigh efficiency, longlived, 10 to 20 year conversion systems including system packaging designed for the naximum reçuiroments of launch safety.

d. Space Reactor Power Systems Surface Applications-The application of reactors on the surface of bodies for Lunar, Martian, and asteroid missions senerates special rogutrements including protection from surrounding elements which may include oxjdizing gases and dust. The surroventing environments may define special requirements and opportunities for heat rejection. The physical deployment of space reactor power systems either robotically or with manned support presents special challenges. In many cases, the system must be

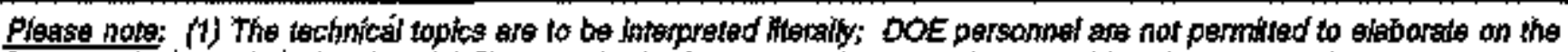

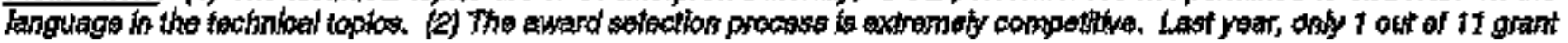

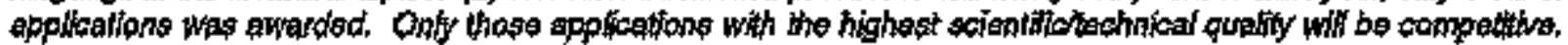


deployed to minimize or shield radiation to surrounding manned operations. Grant applications are sought, for innovative materials and concepts useful for adapting reactors to the above surface environments; approaches for deploying Lunar, Martian, and asteroid space reactor power systems that meet the above special needs; and unusual or innovative reactor systems for processing and/or utilizing space resources.

\section{Bibliography}

1. "Advanced Power Sources for Space Missions," Committae on Advenced Space Bared High Power Technologies, Energy Engineering Bosrd, Commiseion on Engineering and Tochnical Systems, National Research Council, NASA Report No. NASA-TM-101811, Washington, D.C. Natíonal Academy Preas, 1989 (NTIS Order No. N89-28563/41).*

2. Allen, C. C., at al, "Space Nuclear Thermal Propulsion Teat Faeilitieg 8ubpanel Final Report," NASA Report No. NASA-TM-105708, April 1993 (NTJS Order Na. N93-25105/6/ $\mathrm{RAB}) *$

5. Baldwin, D. and J. S. Clark, "Space Exploration Initiative CandidateNuclear Propulaion Test Facilitios," NASA Report No. NASA-TM-105710, April 1998 (NTLS Order No. N98-24753/4XAB).*

4. Clark, J.S, et al, "Nucleser Thermal Propulajon: A Joint NASA/DOEJDOD Workehop, Clevelend, OH, July 10-12, 1990," NASA Report No. NASA-TM-10079, 1991 (NITS Order No. N92-1108A $/ \mathrm{XAB})$.*

5. Clark, J. S., et al, "Nuclear Thermal Propulajon: Reaulto of an Interagency Panel in 1991," NASA repart No. NASA-TM-105711, April 1998 (NTIE Order No. N9324740) *

6. Doherty, M. P. and R. S. Holeornhe, "Summary and Recommendations on Nuclear Flectric Propuleion Technology for the Space Exploration Initiative," NASA Report No. NASA-TMA-105707, April 1999 (NTIS Order No. N\$8-24744/3XAB),"

7. Final Environmental Impact Statement, Space Nuclear Thermal Propulejon Program, Particle Bed Reactor Propuleion Technology Development and Validation. May 1993: $\Rightarrow$

8. Nuclear Propulsion Pechnioal Interchange Merting, Volumes $I$ and 2, Sandusky, $O H$, October 20-23, 1992, NASA Report Nos. NASA-CP-10116-VOL-I; NASA-CP. 10116-VOL-2, 1993 (NTIS Order Noo. N98-26908; N98. 26951)* *

9. Procedings of the Intersociety Energy Conversion Engineering Conferentce, New York: LEEE (Current and past annual meetinge.).***

10. Scheek, A, "Degign Evolution and Verification of the 'General-Purpoee Fieat Source'," Proceedings of the Fifienth Intersociety Enengy Conversion Engineering
Conference: Volume 2, Sertile, WA, August 18-22, 1980, Washington, D.C.: Aperican Institute of Aeronnutics and Aftronautice, 1980.

11. Transactions of Sympasiz on Space Nuelear Pouver Systems, Univergity of New Mexico, Albuquerque, NM: The Institute for Space Nuclear Power Studies (Current and past annual meetínge).

\section{See Section 7.1}

** Available from Air Force Center for Environmental Bxcellence/RSE, 8108 Chennault Roed, Brooks Air Force Base, TX 78235-5318 (Telephone 210-636-3906)

*** Available fram IEEE Service Center, 445 Hoes Lano, Piacateway, NJ 09864 (Telephane 800-678-4893)

\section{MEASUREMENT AND CHARACTERIZATION OF MATERIALS IN CIVILIAN NUCLEAR REACTORS}

The continued viability of nuclear power will require proper charecterization and demonstration of materials performance for thase systems, structures, and components considered eritical for safe operation of a nuclear facility. DOE has identified a need to enhence present technologies through innovative technology-based research and development on approaches to: (1) meagure the mechanical properties of nuclear reactor pressure vessel (RPV) materials, (2) enhance the capability of in-service inspection technology to varify the absence of service-induced defents in reactor pressure vessels, and (3) determine cable jacket and insulation properties for electrical cables. Grant applications are invited only in the following subtopica:

a. Measurement of Nuclear Reactor Pressure Vesgel Mechanical Properties-The characterization of RPV integrity (through material property determination) is a critical safety assessment. Thermal annealing of RPVs may increase the amount of naterial property testing required. One means of characterizing the integrity of RPVs is to monitor mechanical property changes of materials susceptible to irradiation embrittlement. However, the fixed amount of available RPV material that can be incorporated into additional surveillance programs may not satisfy the increased level of testing required. Innovative mechanical property measurement techniques that 
reduce the amount of material required will provide surveillance program options. Grant applieations are scught to develop in-situ nondestructive evgluation technology which tests the minimal amount of material required to determine mechanical properties (Charpy jmpact, tensile and fracture toughness) of RPV materials subjected to irradiation embrittlement.

b. In-Service Inspection Technology-Repulations established by the Nuclear Regulatory Commission require nondestructive inspection of RPV beltline materials (material direct)y adjacent to the effective height of the nuclear fuel core) to ensure RPV integrity by verifying the absence of service-induced defects. Characterization of the inspection system performance parameters (probsbility of detection and sizing accuracy) is vital if the results of a vessel-specific, in-service inspection are to be used to provide a realistic assessment of RPV integrity. In addition, physical constraints in the RPV may preclude $100 \%$ inspection of the beltline region using avajlable techniques. Previously, exemptions to a $100 \%$ inspection were allowed if physical constraints prechuded ingpection using available technologies. Recent regulatory changes no longhr allow these exemptions and require inspection of over 90 percent of the examination volume. Grant applications are sought to develop: (1) innovative approaches to determine the probability of detection and the sizing accuracy for nondestructive inspection systems, and (2) innovative technologies that allow in-service ingpections of those parts of the beltline regton that are otherwise inaccessible using present techrigues.

c. Electrical Cable Jacket and Insulation Properties-Electrical cables are subject to various types of environmental aging (e.g., thermal and irtadiation aging). In critical applitations, including civilian nuclear power plants, more presise measurements of the effects of environmental aging can be used to accurately predict the remaining gualified life of a cable. Electrical cable jacket and jnsulation material properties have been direstly correlated to mechanical testing results, including elongation and tensile strength. Accurate measurements of electrical cable jacket and insulation materials, combined with the results obtained during the initial environmental qualification program, will help ensure that adequate safety margins are maintained. Grant applications are sought for technologies that will allow in-situ mechasieal measurements of electrical cable jacket and jnsulation properties. Non-destructive techniques are of primary interest; techniques that require small samples from the ends of a cable or very lacalized samples will aliso be considered.

\section{Bibliography}

1. Cheremissinoff, N. P, Handbook of Polymer Scienca and Techmologxt Volame 2: Performance Propercicise of Plaetics and Edestomers May 1989 (ISBN No. 0-8247. 6174-0).

2. Gieske, J. H. and H. M. Frost, "Sound Yelncity Mfeasurements in Green-Body Cerantios as a Function of Sintering Temperatures," Beriow of Progreas in Quantitative Nondestructize Evaluation, Volums BE,D. O. Thompeon and D. E. Chimenti, ade., CONF-8B0760, Now York: Plenum Presis, 1989.

3. Gillen, K. T., at al, Deneity Profiling of Polymers," Polymer, 27(2):225-292, Bebruary 1986 (ISSN 00828861).

4. Gillen, K. T, "Madulue Profiling of Podymers, " Polvmer Degradation and Stability 17(1):81-47, 1987 (ISSN 0141.3910).

5. Haggas, F. M. "In-Situ Medaburements of Mechanical Propertien Uaing Novel Automated Bell Indentation Syotem, ${ }^{2}$ In Sinall Spectman Teat Techriques Applied to Nuclear Raactor Vesel Thermal Arnealing and Plant Life Extension, ABTM STP 1204, Philadalphis, PA: ABTM, 1993.

6. Hutchins, D. A., ot al, "Some Applications of LasorGenerated Ultrasound in Matals," 1981 Uthrzenics Symposium Proceedings, Chicago, IL, October 14-16, 1981, pp. 798-801, New York: IEES, 1981 (IFASE Catalog No. 81CH1689-9).*

7. Jacobus, M. J., od, "Agíne, Candition Monitoring, and Logs-of-Coolant Acefdant (LOCA) Tegts of Clace $1 \mathrm{E}$ Electrical Cableg," Report No. NUREC/CR-5772V2, Sendia National Laboratory Report No. SAND.91$1766 / 2$, November 1992 (NTIS Order No. TI9\$004668).**

8. Jacobus, M. J., ed., "Aging, Condition Monitoring, and Loes-of Coolent Aceident (LOCA) Tosts of Clans $1 E$ Electrical Cables: Summary of Results, " Proceedings of the U.S. Nuclear Regulatory Corrmission Nineteenth Water Reactor Safety Information Meeting, Betherda, MD. Oetober 28-30, 1991, CONF-911079-Vol.1, Report No. NLREG\%P.0119-V1, April 1992 (NTIS Order No. T792013798)."**

9. Kumar, A. S., et al, edk., 'Subsiza Specimen Testing of Nudlear Reactor Pressure Veeol Materlal," Effect of Radiation on Matarialst I ath International Symposizm, ASTM ETP 1175, American Soeisty for Testing Materfals, Philedelphia, 1998.

10. Mettson, $B_{\text {, }}$ et al, "Noval Tochriques Ueed to Assegs the Aging of Carben-Black-Filled Materials," Polvmer 
Degradation and Stability, 41(2):211-2z1, 1993 (ISSN 0141-9910).

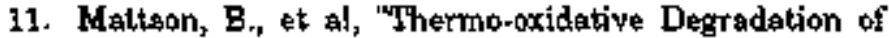
Thick-Walled Rubber Materials Studifed by IR-Technique and Computed X-Ray Tomography Scanning," Rubber Chemistry and Technology, 63(1):23-31, 1990 (ISSN $0035-9475$ ).

12. Pereson, S. and E, Obtman, "Ube of Computed Tomography in Nondestructive Teating of Polymeric Materials," Applied Dptics 24:4095-4104, December 1 , 1985.

19. Rosinski, S. T, et al, Application of \$ubsize Speximens in Nuclear Plant Life Extension, in Small Specimen Test Tectniques Applied to Nuclear Reactor Vessel Thermal Annealing and Plant Life Extension, pp. 405-416, 1993, CONF-920146 (ISBN 0-809 1-1869-4).

14. Tanaka, U., et 81 , 'Prediction of Large Specimen Fracture Toughness From Small Specimen Tests," Thiteenth MPA Seminar on Safety and Reliabitity of Pressure Components: The Contribution of Compronent and Large Speciner Tasting to Strututual Integrity Assessment Methodology, Stuttgard, Garmany, Octoher 8, 1987, CONF.8710410-, Nuglear, Enginearing, and Design, V112, March 1989.

* Available from the IEEE Service Center, 445 Hoes Lane, Piscataway, NJ 08854 (Telephone 800-678-4333)

$*$ See Section 7.1

\section{CHARACTERIZATION, MONITORING, AND SENSOR TECHNOLOGIES FOR RADIOACTIVE AND HAZARDOUS WASTE}

DOE is committed to the cleanup of radioactive, hazardous, and mixed waste at its facilities by the year 2019. A new approach to environmental research and technology development at the DOE was adopted in January 1994, with action plans to address the following focus areas: contaminant plume containment and remediation; high-level waste tank remediation; mixed waste characterization, treatment, and disposal; landfill stabilization; and facility transitioning, decommissioning, and final disposition. Characterization and montoring technology is required for all tive focus areas. Characterization/monitoring technology that is developed for addressing needs in one focus area can often be adapted to solve similar problems in others. However, this topic focuses on technology development of particular relevance to high-level tank wastes, lowlevel mixed wastes, decontamination and decommissioning, and sensors for robotic applications.

Each grant application must include evidence of communjcation with and appreciation of the needs of prospective customers. The feature(s) to be characterized/ mionitored, the target limits of detection, eceuracy, and precision, and the target measurement ranges must be clearly stated and must be consistent with the functional and operating requirements of the prospective customers. Information concerning the baseline technology (if any) and its performance must be provided so the potential value of the proposed technology development can be assessed. Grant applications are invited only in the following eubtopicse

a. Characterization and Monitoring of HighLevel Waste Tanks-Approximately 200 large underground storage tanks were used to capture. process, and store radioactive waste from weapons material produetion processes. These tanks contain highly radioactive sludge, saltcake, and supernatant, liquid. The major chemical constituents are nitrates, along with hydrated metal oxides, phosphete precipitates, transuranics, and isotopes of strontium $\left({ }^{90} \mathrm{St}\right)$, iodine, cesium $\left({ }^{197} \mathrm{Cs}\right)$, and technetium $\left({ }^{(08} \mathrm{Tc}\right)$. Characterization/monitoring technology improvements are needed to help address waste tank safety issues, including tank leak monitoring, and to help support the safe retrieval, pretreatment, and processing of tank waste. Grant applications are sought for the development of: (1) systems for in-situ determination of the following at various waste matrices (liquids, saltcake, and sludge) within the tanks: water content (woight percent), total orgenic carbon content (weight percent), fissile material ( $\left.{ }^{240} \mathrm{Pu}\right)$ content $(\mu \mathrm{g} / \mathrm{g})$, and heat generation ( ${ }^{4} \mathrm{Sr}$ and ${ }^{\mathrm{ct}} \mathrm{Cs}$ ) (Btu/hr-lb); and (2) systems for continuous, real-time detection of tank leaks during waste storage and waste retrieval operations. Devices and systerns for $\mathrm{tn}$-situ deployment must be capable of performing in a caustic environment and a radiation field of $5,000 \mathrm{rad} / \mathrm{hr}$ for an accumulated dose of $10^{7} \mathrm{rad}$.

b. Low-Level Mixed Waste (LLMW) Process and Effluent Monitoring-ILMW contains small amounts of radioactive material mixed with material that contains one or more hazardous chemicals. DOE's $107,000 \mathrm{~m}^{3}$ LL.MW inventory includes hundreds of different chemical and physical waste matrices. A varisty of treatment and waste stabilization 
tochnologies are under invegtization and development. Incineration, plasma processing, and vitrification are axamples of the former; polymer and grout encapsulation exemplify the latter. All LLWW treatment/ stabilization prosesses reguire some characterization monitoring to help ensure the production of acceptable tinal waste forms. Treatment of LLMW requites destruction of hazardous organic constituents and stabilization of hazardous inorganic constituents to comply with land disposal restrictions. In addition, effective remove] of pollutants from off-gas effluent of the treatment processes needs to bs accomplished and documented at levels that satisfy all applicable local, state, and federal requirements. Grant applications are sought to dovelop techniques for determining the presence and concentration of volntive metals (mercury, lead) and the totai salt content (sodium chloride, potassium chloride, along with sulfates, nitrates, and some fluorides) in wet solidis, hetero. genous dry solids, and homogeneous dry solids. Grant applications are also sought for the development of tochnigues for continuous, real-time monitoring of radionuclide, total orgenic carbon, and Resource Conservation and Recovery Act (RCRA)-listed heavy metal concentrations at various points in mixed waste treatment process streams.

c. Characterization Support for Decontamination and Decommiegioning ( $D$ and $D$ ) ActivitiesMany of DOE'B nuclear materials processing facilities are contaminated with radioactive and/or hazardoos materials. Examples include uranium, plutonium, and other special materisls processing facilities, and reactors, hot $\mathrm{cells}$, and irradiated fuel storage fawilities. These facilittes must be decontaminated and decommissioned, and valuable materials must be recovered. Extremely lerge quantitios of materials will be targeted and generated by D and D activities. Recovery and reuse of some of these materials, including metals, concrete, and equapment, offer the possibility of large economic benefits. New technologies are needed to help characterize facilities and materials scheduled for $D$ and $D$ and to monitor the $D$ and $D$ processes to ensure safe operation, release of recovered materials for reuse, and appropriate control and disposition of secondary waste. Grant applieations are sought to develop: (1) techniques that provide the capability of large area coverage with three-dimensional mapping to identify polychlorinated biphenyls, uranium, plutonium, fission products, and mercury in the nearsurface layer of concrete (techniques capable of "seeing through" soatings such as paint and epoxy are of special interest), (2) a real-time alpha sensor for determination of activities in solutions, ranging from $\mathrm{Ci} / \mathrm{L}$ levels for flush solutions to $\mu \mathrm{Ci} / \mathrm{L}$ levels for final decontamination conditions (this sensor will help resolve criticality issues and provide informetion for evaluating the effectiveness of decontamination operations); and (3) technologies for the cheracteriza. tion of metal scrap volumetrically contaminated with ${ }^{\text {a } \mathrm{Te}}$ and activation products such as ${ }^{\mathrm{B}} \mathrm{Co}$.

d. Sengore for Robotic Applications-Robotic technology has potential for enhancing the safety of operations in many of the fotus areas identified above. Current robptic development efforts address: (1) waste storage tank inspection, waste characterization, and retrieval; (2) buried waste characterization, retrieval, and remediation; (3) remote and automated inspection of interim stored waste; (4) contaminant analysis automation; and (5) mobile facility surveyors and decontamination platforms. Sensors are neded to help support the application of robotics for remote sensing, operation, and control of equipment; for minimization of worker expesure; and for enhencement of opergtional throughput. Grant applicetions are sousht for the development of the following sensors with emphasis an minumization of weight, volume, power consumption, and supporting peripheral equjpment requirements: (1) sensors for real-time determination of heavy metels and organic chemicals listed in the Resource Conservation and Recovery Act, and (2) miniature alpha/gamms radiation sensors for detection of mixed samples.

\section{Bibliography}

1. "Characterizetion, Monitoring, end Seneor Technology Integratad Program (CM(STI-IP): Technology Summery," U.S. Dopartmont of Bnergy, Washington, D.C., Repart No. DOELM.0156T, April 1994**

2. "The Department of Energy"s (DOE) Environmentel Reptoration and Waste Menazemont Five-Year Plan for FY 1904-1009", U.S. Department of Energy, Wesh. ington, D.C., p. 177, Auguat 1993, Repart No. DOBs: 0097P.V3 (NIIS No. DE98040660), **

3. Harlon, B. M., "Tenk Farm Surveillance and Waete Status Summary Report for Fobruary 1994," p. 162, 1994. Report No WHC-EP-0182-71 (NTIS No. DP94014591),***

4. "A New Approach to Envirommentel Regeatch and Techrology Dovalopinent at the US. Depertment of Energy: Action Plan," U.S. Department of Energy, Washingtor, D.C., January 1994. 
5. "Recommendation 93-5 Implementation Plan," U.S. Department of Energy, Richland, Washington, p. gs, January 1994, Report No. DOEJRL4-0001 (NTIS No. DE94011397) **

b. "Robotics Technology Development Program; Technology Summary," U.S. Department of Energy, Washington, D.C., p. 110, February 1994, Report No. DOE/DM-0127P (NTIS No. 94008859), *F

7. Technical Program Plan for the Trangitioning, Decommissionine, and Final Disposition Focus Area, U.S. Department of Energy, p. 801, January 1994, Report No. DOENBM-1101, (NTIS No. DE94005597) **

8. "U.S. Department of Energy Interim Mixed Waste Inventory Report: Wagte Streams, Treatment Capacities and Technologias, Volume 2-5," Report Nos. DOENBM$1100-$ Vol. 2.Vol. 6, U.S. Department of Energy, Washington, D.C., April 1993 (NTIS Order Nos. DE93012087; DE93012098; DE93012099, DE93012100; DE98012101).**

* Available from Ampo Laboratory, I07 Spadding Hall, Amer, Iowa $\mathbf{0} 0011-3020$

** See Section 7.1

\section{IN-SITU TREATMENT OF METAL CONTAMINATED SOILS AND GROUNDWATER}

DOE operates 18 research and production facilities throughout the United States. More than 3,000 inactive waste sites have been identified at these facilities, including both engineered disposal facilities and sites of unplanned releases. Metals, including radionuclides, were found to be among the most prevalent contaminants throughout the complex. Common contaminants include tritium and the metals lead, chromium, arsenic, zinc, copper, cadmium, nickel, rnercuty, uranium, barium, cesium, strontium, plutonium, thorium, and technetium. In many cases, sites containing these metals are also contaminated with organic acids, complexing agents, and organic solvents. These contaminants have migrated into the groundwater.

$\mathrm{DOE}$ is interested in the development of innovative technology systems for in-situ removal, extraction, or destruction of metal contaminants in the soil's vadose zone (the unsaturated zone between the ground surfact and the water tablel in order to eliminate the need for soil excevation for subsequent treatment and disposal.
Specific technolocy systems of interest are those that will either reduce the leachsbility of the metals in the soil (stabilization, chemical or electrochemical reduction, etc.) or increase the netal mobility to enhance recovery of the metals from the soil using an extraction well.

DOE is also interested in the development of systems for the in-situ treatment of metal contaminated groundwater. A technology mast be developed to concentrate contaminants prior to extraction. This is necessary to either minimize or eliminate the volume of water recovered through an extraction well prior to above-groond treatment. Subsurface contaminated soils that are above the groundwater table are of particular concem, Of interest, are specific technologies that will either permenently reduce the solubility of the metals in the groundwater in order to eliminate the need for their recovery, or would enhance metal mobility and/or concentration of the metals in the groundwater to improve the efficiency and effectiveness of purnp and treat technologies.

Principal issues precluding demonstration of many of the physical, chemical, and biological treatment technologies include the lack of performance data specific to the contaminants at DOE sites and the need to demonstrate eftrient dispersal and/or collection of chemical reagents in an in-situ application involving unsaturated soils. Grant applications are invited only in the following subtopics:

a. Stabilization of Metals in Vadope Zone Soils-Grant applications are sought for innovative processes that stabilize metals in subsurface vadose zone soils located above the eroundwater zone. Stabilization involves technologies that reduce the mobility of contaminants in soils and sediments by physically or ehemically binding them to the soiv sediment matrices. Techniques that may be employed in these processes include the addition of liquid or gaseous reagents to form insoluble precipitates, adsorbents to strongly adsorb soluble contaminants, or the addition of grout to form a monolithic material that has a low hydraulic conductivity and aither physically or chemically binds the contaminants within the monolith Other techniques that car be shown to achieve similar objectives will also be considered. Grant applications must: (1) consider the effects of gravity and zoil heteroganeity on the movement of reagents in the soil within the contaminated zond, (2) account for the effect of reactions of reagents with the 
soil and conteminants on the physicel properties of the soil, (3) identify and integrate supporting technologies (i.e., drilling, taixing schemes, monitoring, etc.) to onsure that a treatment system will eventually be available for application, (4) show plans to demonstrate the effectiveness of the proposed technology in groundwater or soil spiked with metals, and (5) establish the bounds of effectiveness according to key parameters by the end of Phase II. The extent of development in Phase II must be sufficient to scale up to a small field test.

b. Enhanced Mobilization and Recovery of Metals in Vadose Zone Solls-Grant applications are sought for innovative processes that enhance the mobility of metals in vadose zone soils located above the groundwater zone and that subsequently recover these metals from the soils. Processes that may enhance metal mobility include those involving the addition of chemical agents such as complexing agents or surfactants, end/or enhanced ion transport using electrokinetic techniques. Research and development are required to demonstrate the delivery and uniform dispersal of reagents to the zone of contamination as well as recovery of metals and unconsumed reagents fron this zone. Grant applications must: (1) consider the effects of gravity and soil heterogeneity within the contaminated zone on the movement of reagents and metals in the soil, (2) account, for the effect of reactions of reagents with the soil or contaminants on the uriform dispersion of reagents, (3) identify and integrate supporting technologies such as containment barriers to ensure that the technology will be acceptable for field application, (4) show piens to demonstrate the effectiveness of the proposed tech-nology in eroundwater or soil spiked with matals, and (5) establish the bounds of effectiveness according to key parameters by the end of Phase IL The extent of development must be sufficient to scale up to a small field test.

c. Solubllity Reduction of Metals in Gronnd. water-Grant applications are sought for innovative processes for stabilizing metals in sroundwater including the sediments with hydraulic conductivities $<10^{6} \mathrm{~cm} / \mathrm{sec}$. These sediments are generally not considered amenable to conventional pump and treat technologies. Research and develogment are required to demonstrate the proposed technolosy including the dellvery and uniform dispersion of reagents throughout the treatment zone in a contaminated groundwater plume. Techniques that may be employed in these processes include the addition of liquid or gaseous reagents to form insoluble precipitates, adsorbents to strongly adsorb soluble contaminants, or the addition of grout to form a monelithic material that has a low hydraulic conductivity and either physically or chemically binds the contaminants within the monolith. Grant applications must: (1) consider the effects of soil heterogeneity within the treaturent zone on the movement or reagents in the saturated sediments, (2) account for the effect of reactions of reagents with sediments and groundwater contaminants on the physical properties of the sediments and on the mobility of the reacted contaminants, (3) identify and integrate supporting technologies (i.e., drilling, mixing schemes, monitoring, etc.) to ensure that a treatment system will eventually be available for application, (4) show plans to demonstrate the effectiveness of the proposed technology in groundwater or soil spiked with metals, and (5) establish the bounds of effectiveness according to key parameters by the end of Phase II. The extent of development in Phase II must bs suffcient to scale up to a small field test.

d. Enhanced Mobilization and Recovery of Metals in Groundwater-Grant applications are sought for innovative processes that enhance the mobility of metals in groundwater and subsequently recover these metals using an extraction well. Processes that may enhance metal mobility include those involving the addition of chemical agents sach as complexing agents or surfactants and/or electrokinetic techniques. Research and development are required to demonstrate the delivery and uniform dispersal of the required reagents to the zone of contamination as well as recovery of metals and unconsamed reagents from this zone. Grant applications must: (1) consider the effects of soil heterogeneity within the contaminated zone on the movemest of reagents and metals in the soil, (2) account for the effects of reactions of the reagents with the soil or contaminants on the physical properties of the saturated sediments, (3) show plans to demonstrate the effectiveness of the proposed technology in groundwater or soil spiked with metals, and (4) establish the bounds of effectiveness according to key parameters by the end of Phase II. The extent of development must be sufticient to scsle up to a small field tast.

\section{Btbliography}

1. "FY 1995 Technology Development Neede Summary," US. Depertment of Energy Office of Environdentel 
Management, pp. 204, March 1994, Report No. DOEJBM-0147P (NTIS No. DE94012580),*

2. Grosse, D. W. "Treetment Technologies for Hazardous Wasteg: Pert TV. A Review of Alternative Trentment Proceseese for Metal Bearing Hazardons Waste Streams," Journal of the Air Potlution Control Assogiation, $36(5)$ 603-614, 1986 (ISSN 0002-2470).

3. Hazardous Materialg In Situ Stabilization Hazardoua Thaterials Control Research Institute, silver Spring, MD, 1987 (ISBN 0-944989-48-8).

4. "In Situ Romediation Integrated Program: Technology Summery," D.\$. Department of Energy OHice of Bhiviconmental Management, Ofies of Technology Development, p. 82, Fubruary 1994, Report No. DOFFM-0134P (NTIS No. DE94008862)*

5. "Innovation Investment Area: Technology Summary," U.S. Department of Energy Dffice of Environmenta] Mansganent, Office of Technology Development, p. 320, March 1994, Report No, DOEJM-0146P (NTIS No. DE94012997).*

6. "Othice of Technology Devalopsuent Program far Research, Development, Deponstration, Testing, and Evaluation," U.8. Depertment of Energy Office of Emr. ronmental Management, October 1098, Report No. DOEGHA-0109P (NTES No. DE94002591)*

7. Riley, R. G. and J.M. Zschare, "Chemical Contaminants on DOE Lands and Selection of Contaminant Mixture for Subsurface Science Research," Report No. DOE/ER0547T, U.S. Department of Enerky, Offec of Energy Research, Wagkington, D.C., 1992. (NTMS Order No. DE2014626).*

B. Sima, R. and J. Bass, Review of In-Place Treatment Techniques for ContamingtedSubsmracte Soils - Volume 1, Technical Bveluation, EPA-540/2-84-008A, Cincinneti, OH; U.\$. Brvironmental Protection Agency, 1984 (NTIS No. PB85-124981/AAB.).*

9. Technology Catelogue", U.S. Degertment of Engrgy, Office of Environmental Manegement, Ofice of Technol. ogy Development, p. 211, February 1994, Report No. DOE/EM-0188P (NTIS No. DE94008866)."

* Sẹe Section 7.1

\section{CHEMICAL SEPARATION PROCESSES FOR WASTE TREATMENT}

DOE's goals for waste management and environmental restoration are to: (1) reduce the volume of waste that must be disposed of in a geologic repository; (2) decrosse the toxicity and minimize the quantity of lowlevel waste (LLW) that is disposed of near the earth's surface; (3) minimize the volume of ptocess, secondary, and decontamination and decommissioning wastes; (4) modify and apply separations methods developed for waste treatment to environmental restoration and waste mandgement activities in remediating soils and groundwater, (5) identify high-value waste constituents for potential recycle; and (6) develop technologios for transfer to commercial use.

Separation technologies can remove radionuclides, hezerdous materials, and chemicals from radioactive wastes (see note below), contaminated soils and groundwater, and waste streams resulting from the decommissioning and decontamination of facilities contaminated with hazardous and/or radjoactive chemicals. Heavy metals, RCRA metals, organics classified as hazardous by the RCRA, and radioactive epecies are typical components of concern in DOB waste streams. Separation technologies must minimize the environmentel impact, risk, and life cycle costs of waste treatment, waste disposal, and environmentel restoration.

[NOTE: Radioactive wastes can include high-level wastes (HLW), low-level wastes (LWW), tranguranic (TRU) wastes, and highly radioactive mixed wastes. HLW is defined as the highly radioattive waske material that results from the reprocessing of epent nuclear fuel, inclading liquid waste produced directly in reprocessing and any solid waste derived from the liquid that contains a combination of transaranic waste and fission prodacts in concentrations requiring permanent isolation. TRU waste is defined as waste that is contaminated with alpha-emitting tranguranic nuclides with hait-lives greater than 20 years and concentrations greater than 100 nanocuries per gram of waste. LLW is defined as radioactive waste not classified as HLW, TRU, spent fusl, or by-product material. Mixed waste contains both radioactive and hazardous components, as defined by the Atomic Energy Act and the Resource Conservation and Recovery Act (RCRA).]

Grant applications, submitted in response to the subtopics listed below, should jdentify separation processes which are selective for specific contaminents of interest; produce low-volume secondary waste streams; and provide high loading cepacities, high seperation factors, and simplicity. Separation processes having commercial applications are strongly encouraged, but, all grant applications should target a DOE problem, Enabling processes for separations (i.e., 
processes which transform the waste streas so that it becomes amenable to subseguent treatment by an established or innovative separation process) are also acceptable. In all cases, the flexibility of the technolosy is important; for example, a technology that addresses muliple contamination situations is preferable to a technology limited to a single situation. Grant applications should describe clearly the advantages of the proposed technologies over existing altarnatives, if any.

For those applicants who do not have the facilities to perform research involving radioactive species, grant applications will be accepted in which an innovative separation technology is demonstrated on a nonradioactive substance; however, the approach, upon further development, must be relevent to radioactive species. Grant applications are Invited only in the following subtopics:

a. Aqueous Waste Streams-Grant applications are songht for innovative ways to separate radioactive species from high jonic strength, multicomponent, aqueous solutions of salts dominated by species such as oodium nitrate, nitrite, carbonate, and phosphate. Related efforts include methods for the removal and/or destruction of non-radioactive but prohlematic compounds sach as aitrates, nitrites, and orcenics (especially RCRA-related oreanics) in radioactive wastes. (Nitrates and nitrites constitute the largest fraction of wastes at some DOE sites, increase volume and cost requirements, increase safety risks, complicate waste processing, and can increase the leaching of other components from waste forms. Hazardous organics pose serious environmental threats and can reduce the effectiveness of some methods for removing metels from waste streams.) Treatment of both acidic (typically, up to several molar in nitric acid) and alkaline (op to several molar in hydroxide) aqueous solutions are of interest.

Grant applications are also sought for separation or enabling processes to remove contaninants and minimize waste streams from dexontarnination and decommissioning operations. Radionuclides and other meterials-under consideration for separation include transuranic (TRU) elements such as neptunium, plutonium, americlum and curium, highly radioactive elements, strontium ( ${ }^{(0)} \mathrm{Sr}$ ) and cesium $\left({ }^{17} \mathrm{Cs}\right)$, long-lived soluble fission products including technetium (oTc) jodine $\left({ }^{129} \mathrm{D}\right)$, and activation products such as tritium end carbon ( $\left.{ }^{14} \mathrm{C}\right)$. In addition to radioactive elements, contaminants on equipment and structure] surfaces at DOE facilittes also include common solvents such as trichlorosthylene (TCE), polychlorinated biphenyls (PCBs), RCRA contaminants, and toxic motals sneh as mereury. Grant applicetions may focus directly on the decontamination process (for example, development of reagents of approaches to selective leaching) or on reduction of the waste streams that are generated by decontamination process reagents.

b. Sludgea and Solid Wastes-Highly radioactive sludges are typically metal oxides with large amounts of potentially soluble materials such as sodium or aluminum. Only about 0.3 percent of the waste is radiosctive. Grant applications are songht for the direct removal of the radioactive materials (e.g., salectave leaching of transuranices and strontium) or for the removal of the bulk constituents (aluminnm, sodium) to leave a smaller volume of high level waste. Methods such as bulk leaching, selective leaching, dissolution, and extraction wil] be considered.

Grant applications are also sought for high temperature and cheminal metheds to sepsrate radionuclides and hazardous elements from solid (e.g. calcined) radioactive waste strearns. Of particuler interest are processes that separate species into concentrated product streams, can withstand a radiolytic environment, are economically viable, can be scaled up to processing rates of 2 to 30 gallons per minute, and are simple to construct and operate.

c. Glass and Vitrifloation Processes-Grant applications are sought for the removal of the following materials from borosilicate glasses and vitrification processes: (1) metals (such as aluminum, zixconium, and chromium) and anions (such as phosphates) that are deleterions to borosilitate glass; (2) species (such as halogens, volatile metals, and rolatile metal oxides) which generate toxic, difficult-to-handle off-gas streams in the vitrification of mixed waste (note: volatile metals, both radioactive and RCRA-regulated, include cesium, lead, mercury, rubjdium, bismoth, cadmium, sflver, and arsenic): (3) sulfates which can separate olit in a melter, producing a highly corrosive liquid; (4) technetium, which exists in a number of different: valence states, distributes to different waste streams daring processing, and has a hijh tuobility in many waste forms; and (5) noble metals (particulerly palladium, rhodium, and ruthenium) which have an adverse effect on the formation of borosilicate glass and can have significant economic value.

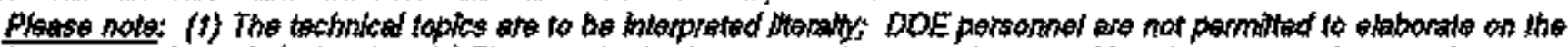

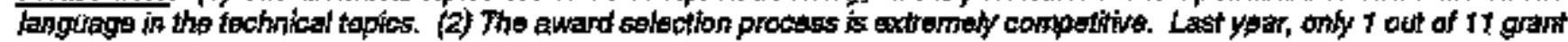

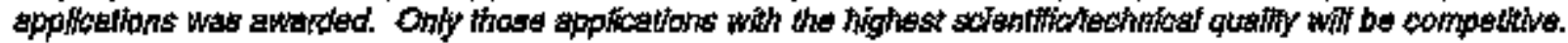


d. Soil and Groundwater Treatment-There are a wide variety of radionetive, toxic, and heavy metal contaminants in the groundwaters and soils at DOE facilities. Some of the most common are uranium, technetium, trichloroethylene, and polychlorinate biphenyls. Grant applications are sought for innovative ways to remove contaminants selectively and efficientiy from groundwater and soils while removing as little non-contaminant material as possible. Solective adsorbents or extractants with high capacity, good mass transfer rates and/or linetics, and high selectivity could be uged ex situ for treating groundwaters pumped from aquifers, and such adsorbents may find applications in situ as "adsorptive barriers" which prevent underground transport of radioactive and toxic contaminents. When the source of the contamination must be excavated and removed, processes such as selective leaching may be needed for species that cannot easily be washed or volatilized. Because all such processes generate secondary waste streams, grant applications must also develop techniques to separate and recycle process reagents from these waste streams.

\section{Bibliography}

l. Han]on, B. M., "Tank Farm Surveillance and Waste Etatue Summary Report for July 1993," Report No. WHC-EP-0182-64, November 1993 (NTIS Order No. DE94004254).*

2. "Efficient Separations and Processing Integrated Program (ESP-1P) Technology Strmary," U.S. Depart. ment of Energy, Report No. DOE/EM-0126P, Eebruary 1994 (NTIS Order No. DE94008B58)*

3. "Environmental Reatoration and Waste Management (BM) Program - An Introduction," U.S. Department of Energy. Ofjee of Environmental teretoration and Waste Manegeunent, Washington, D.C., Report No. DOE/EM0013P, June 6, 1991 (NTIS Order No. DE91018290).*

4. "Eavironmsntal Reatoration and Wagte Maragement FYve-Year Plan, Fíced Yeares 1994-1998," U.S. Depertment of Energy. Report Nos. DOE/S-000seP; DoEs-000997P.Vol. 1; DOES-00097P.Val, 2, U. Departinent of Energy, Weshington, D.C., Jepuary 1998 (NTIs Order Nos. DE99005906, DE93043882; DE98004781).*

5. "Office of Technology Development Pragram for Reaserch, Development, Demonstration, Testing, and Eviluation," Report No. DOEJEM-0109P, October 1998 (NTIS Order No. DE94002591)*

6. "Long-Lived Legacy: Managing High-Level and Transuranic Waste at the DOE Nucloar Weapons Complex," US. Department of Energy, Ofice of Technology
Agregsment, Weghington, D.C., Repert No. OTA-BP-088, May 1991 (NTIS Order No. PB91-186205/XAE).*

7. "Undergroond Storage Tank Integrated Demon stration (UST-ID)," U.S. Department of Energy, Report No. DOESM-0122p, February 1994 (NTIS Order No. DE94008854)*

8. Techpology Catalogue, U.S. Department of Energy, Office of Technical Dovelopment, Weshington, D.C. February 1994 (NTIS Order No. DB94008658).*

* Ses Section 7.1

\section{COMPUTER STORAGE AND ANALYSIS FOR NONPROLIFERATION DATA COLLECTION}

Treaties to enforce international nonproliferation goals include the Nuclear Nonproliferation Treaty, Open Skies, and the pending Comprehensive Test Ban Treaty. The implementation of these treaties requires the utilization of sensor data from setellites, aireraft, and on-site inspections. Large amounts of imaging and multispectral data, as well as data from ground geographical positioning systems, are collected. Current techniques to compile, correlate, and analyze these data are so time consurning and cumbersome that often high confidence conclusions cennot be reached in the required decision time frames. The international commanity has a need for computerbased technigues which can corntmunicate, store, and screen data, perform statistical enalyses, and display high confidence results coordinated to the geographical positioning information in near real-time. Grant applications are fnvited only in the following subtopics:

a. Data Fusion and Statiatical Analyais-The amount of data collectod during treaty verification is overwhelming. If decisions based on these data are to be made in a timely manner, critical data must be extracted, integrated, anglyzed, and presented to decision makers in real or near-real time. Grant applications are solicited for smart systems which are capable of automatically screening and anelyzing date collected during treaty verification and presenting the pertinent results geographícally. 
b. Neural Networks-Grant applications are solicited for a practical and convincing demonstration which uses a neural network to analyze data collected during the implementation of arms control and nonproliferation treaties. The demonstration should be based on digitaliy stored data retrieved from multiple and independent sources (such as those listed in the introduction paragraph above) or on analytical data to indicate the presence of a signal in a variable noise background. The demonstration must clearly show the advantage of the proposed system over existing systems in terms of unit cost, processing, time, or analysis accuracy.

c. Digitjzing Images and Data Base StorageMuch of the data collected by inspection is in forms which are not conducive to automated computer processing in a standardized data base (i.e. photoerophs, maps, site plens, still video, full motion video, analysis results, meteorological data, sampling conditions, time-lapse film and video). (Grant applications are sought for innovative ways to transform these data to digital form with low error rates. Grant applications zoust show improvements over existing commercially available schemes and produce data bases in standard form which can easily be used in fusion and neural network algorithms.

d. Non-Keyboard Input-Internationel Atomic Bnergy Agency inspectors rely on notebooks, sempling kits, imeging systems, and specialized instrumentation to gather data during field inspections of nuclear facilities. Grant applications are solicited for automated, man-portable systems to perform record keeping and process the instrumentation data in real time fot transfor to, and later interpretation by, a host computer. Such systems would significently reduce the time required for inspectors to be on site. Since manual and keyboard systems are too cumbersome for field use, other approaches such as voice digitization or touch screen entry are also sought.

\section{Bibliography}

1. Dowla, $F$. and R Leach, et al, "Neural Network Methods In Hydrodyuamic Yield Eatimationt," Pure and Applied Geapingicg, V140:N3X427-454), January 1993 (ISSN $0083-4558$ ).

2. Hapfield, J. J., "Neural Networks and Phyoical Systems with Emergant Collective Computational Abtittes," Procoedings of the National Academy of Eriences of the
Unitad States of America-Biological Siciences, V79:N8 (2554-2558), 1982 (ISSN 0027-6424).

8. Hopfeld, J. J., ede ,Proceedings of the Nuclear Arms Technologies in the 1990's, Weshitrgton, D.C., April 16, 1988, V178, CONF-8804202 (ISSN 0027-6494).

4. Lamb, F. K, Monitoring Yjelds of Underground Nuclear Tests Uaing Hyutrodynamic Msthods, "Proced. ings of the Nuclear Arms Teshnologites in the 1980's, Whahingtom, D.C., April 16, 1968, V176:N1(109-148), CONF-8B04202 (IBSN 0094248X).

\section{LASER TECHNOLOGY FOR CHEMICAL ANALYSIS FOR NONPROLIFERATION ACTIVITIES}

Laser-based measurement technology has become no important tool to remately analyze effluents for nonproliferation and environmental purposes. While the applications will vary with each specific scenario, advances in lasers, optical filters, and sensor technolopy will promote their feasibility. Grant applications are invited only in the following subtopics:

a. Tumable Lasers-Crant applications are sought for solid state tonable lasers which operate in the ultraviolet range from 250 to $400 \mathrm{~nm}$ or in the infrared region from 1 to $5 \mathrm{~mm}$ and/or 8 to $12 \mathrm{~mm}$. A high repetition tate ( $50 \mathrm{H} z$ or better) and high average power are required. These lasers must be capable of being used in the field to remotely detect effluents. As a result, they should be rugged, compact, portable, and efficient. Lasers which axe limited to laboratory use will not be considered. Grant applications should compare the innovation to existing commercially aveilable systems.

b. Laser Components-Grant applications are sought for laser components that will enhance the ability of tunable lasers to detect effluent species. Key components which have been identified are the development of non-linear crystals used in tunable lasers, electrouptic erystals used for modulating laser ight, vltraviolet detector exrays, and diode pumped laser pumps. These components will receive primary consideration, but other innovations that improve the ability of a tunable laser to remotely detect effluents will also be considered. Components of the most interest will enhance tunable lasers in the 250 to 
$400 \mathrm{~nm}_{2}, 1$ to $5 \mu \mathrm{m}$, and 8 to $12 \mu \mathrm{mm}$ wavelength ranges. Crystal innovations must inprove the conversion rate of photors for the tunable laser, create a higher damage threshold for the laser, and/or improve the transmission through the tunable laser. The ultraviolet detector arrays must improve the signal-to. noise ratio for multi-wevelength analysis of weak signals and provide greater speed for time/range gating over axisting charge-coupled detectors. The diode pumped laser pumps must. lower the cost and increase the power and efficiency over existing pumps. All components must be capable of being used in the field and should be nugged, compact, portable, and efficient. Grant applications should compare the innovation to existing commercially available systems.

\section{Bibliography}

1. Conference on Lapers and Electro-Opticz, CLEO '94: Summaries of Papers Fresented at the 14th Conference on Lasers and Electro-Optias, May 8-13, 1994, Anaheim, CA (ISBN 1-6575-2340-1).

2. Fejer, Martín M., "Non-Linear Optical Frequency Conversion," Physicg Today 47:5 p. 25(8), May 1994.

a. Measures, Raymond M., Laser Remote Sensing, New York:Wiley, 1984 (ISBN 0-8946-4619-2).

4. Shem, Y. R., Principles of Non-Linear Opties New York:Wiley, 1984 (ISBN 0-4718-\$996-9).

6. Yariv, Amnon, Optical Electronica, 3rd Edítion, New York:Holt, Rinehart, and Winston, 1985 (ISBN 0.0804 7444-2).

\section{IMPROVED SENSOR TECHNOLOGY FOR NATIONAL SECURITY AND NONPROLIFERATION OF WEAPONS}

Smaller, cost-effeetive, and more rugged sensors are required for numerous applications concerning national Eecurity and the nonproliferation of weapans of mass destruction. Data collected by these sensors must be compatible with common]y-available communication and data base standards to facilitate data retrieval for reaI-time analysis. Graut applications are invited only in the following subtopics:

a. Chemical Species Microsensors-Current sensor systems for nuclear effluent or chemical weapon manufacture detection used by nonproliferation inspectors are bulky and cumbersome, and alternative systems most be developod to collect and store data. A microsensor on an inteerated computer chip (IC) woxld be essential to the development of this type of detector. Grant applications are sought for the development of such microsensors which must be compatible with existing IC standards, controllable by an exjsting standard microprocessor, and show significant improvement over currently avalable commercial sensors.

b. Biometric Sensors for Security Applications-The existing method of photo badge presentation to a security guard for persontrel identification is cumbersome and subject to erroneous identification. Grant applications are sought to develop unique biometric authentication sensors which utilize, for example, hand geometry, fingerprint identification, and/or voice recogrition to enhance the effieiency of security at DOE facilities. Grant applications raust clearly show cost effective innovations in biosensor technology to improve the current methods. Sensor performance characteristics of primary importance are invulnerability to tampering, non-intrusiveness, and high throughput rates.

c. Underground Structures Sensor Technology-National secarity agencies, federal and local law enforcement organizations, and arms control organizations are just a few examples of entities which have requirements for improved capability to detect and characterize underground targets. Of particular interest are sensors to detect buried spaces such as bunker or command-post structures, tunnels and cables, and rocket motors. Handheld or portable geophysical and remote sensing techniques developed over the past two decades have been promising but are limited in detection range, sensitivity, and user friendly operation. Grant applications are solicited for technology that will extend the existing detection capabilities of these sensors from meters to tens of meters or more when using airborne or handheld operations.

Bibliography

1. Bright, D. C., "Exarnining the Roligbility of a Hand Geometry Identify Verification Drovice for Uee in Accees Control," Master's Thesis, Neval Poetgraduate School, 
Monteray, CA, p. 40, March 1987 (NTIS Order No.AD. A181 467/2/XAB).*

2. Haykin, M. E. and R. B. J. Warnar, "Smart Card Technology: Naw Methode for Computer Acceas Control," p. Ea, Septernber $19 a 9$ (NIST Order No. SP. 600/167)*

s. Holmes, J. P., at al, "Automated Biometric AccosB Control Bystem for Two-Man-Rule Enforcement," Conference Procseditings for Institute of Nuclear Materials Management (TMMA) Annual Meating (92nd), New Orleans, LA, July 28-\$1, 1991, p. 15, 1991, CONF920774-59 (NTIS Order Na. DE91016122/RAB).*

4. Holntes, 3. P, at al, "Performance Evaluation of Biobnetric Identification Devices," p. 29, Juns 1991 (NTIS Order No. DE91014674XAB)."

6. Holmes, J. P., et al, "Pertormance Evaluation of Biometric Identificetion Devices," Prodeedings for Insti. tute of Nuctent Materials Management Conference, Los Angeles, CA, p. 13, June 1990 CONF-90071065 (NTIS Ordar No.DF90012917/XAB)**

6. Masesca, Darid A, "Exemining the Effect of Thansverese Motion on Retina! Blametric Identlfiere Ralating to Shophoert Security Mechaniams," Master's Theais, Naval Postgraduate school, Monterey, CA, p. 64, March 1986 (NIIS Ordar Na. AD-A168 990/6/XAB).*

7. Maxwell, R. "Performance Tasting Biometric Vorifiers," Procasding for Aduanced Security and Identitioation Technologies Conference, Washington, D.C. Mcy 29. Juns $t$, t990 CONF-900516a-1 (NTIS Ordar No. DE90008679/XAB):*

8. Maxwell, R. Lt, Status of Personnal Ldentity Verifiers, Conference Proceeding of Annutul Meating of the Institute of Nuctear Materials Management, Albuquargue, NM, duly 21, 1986 p. 6 (NTIS Ordor No. DE8501711S/XAB)."

9. Maxwell, B. L. and L. J. Wright, Performance Evaluation of Peraonmel Identity Vertliers," Conference Procesding INatM Annual Meeting on Safoguards: A Mature Technology, Nexupart Beach, CA, Jthly 12, 1987, p. 22 CONF-B70713-15 (NTIS Order No. DE87012855/XAB)**

10. Price, W. L., "Revjew of Mathode of Personal Idantity Verification," p. 21, 1986 (NTIS Onder No. PB87. $1258 \mathrm{Q} 6 \mathrm{XAB}), *$

* See Section 7.1

\section{ENVIRONMENTAL TECHNOLOGY FOR NATURAL. GAS, OIL, AND COAL}

The desiem and development of fossil fuel processes must consider possible adverse effects on the environ- ment. New environmental protection requirements are constantly under consideration by EPA, Congress, States, and others, as laws are reauthorized or amended.

Research and analysis can provide needed data and remediation methods for natural gas and oil recovery processes, and for ges field operations, to minimize the environriental impact and the cost of complying with regulations.

In eddition, coal is a solid fuel containing components that are precursore of environmental pollutents or materials that are potentially damaging to downstream components. These deleterious materiels include nitrogen and sulfur which form undesirable oxides during combustion. Further, cool contains mineral matter that is enverted into ash that can lead to suspended particulates in air, erosion of or deposition in downstream components, and problems in solid waste disposal. Recently, there has also been concern about the effect of carbon dioxide from coal combustion on the giobal climate.

Grant applications are invited only in the following subtopice:

a. Beduced Bmisatons from Coal Flue GasesGrant; applications are sought to develop technologies to characterize and reduce emissions of toxic air pollutants in five gases resulting from coal combustion. The pollutants of interest are: (1) toxic trace elements, especially mercury, $\mathrm{Cl}_{2}$, and HCL; (2) respirable particulate matter (less than 10 microns in diameter); and (B) sulfur dioxide $\left(\mathrm{BO}_{2}\right)$, nitrogen oxides $\mathrm{NO}, \mathrm{NO}_{2}$ and $\mathrm{N}_{2} \mathrm{O}$ ), and carbon dioxide $\left(\mathrm{CO}_{2}\right)$ from atmospheric coal-fired combustors. Capture of at least $90 \%$ volatilie species, such as mercary, is destred. Devices must be able to perform in the hot, dirty environment produced by the combustor. Regarding (2) above, particulate control devices should achieve collection efficiencies of $99.99 \%$ in this size range and be capable of handling ges streems with fluctuating characteristics produced by cyclic combustor operations. Regarding ( 3 ) above, technologies must treat flue gas downstream of the air preheater, be applicable to coal-fired systems in the electric utility and industrial sector, achieve a high degree of operationel reliability (greater than 99\%), and have low operating and capital costs. Parasitic energy requirements (encompassing the use of pumps, fans, reducing gases, steam, and fuel) for $\mathrm{SO}_{2}$ and $\mathrm{NO}_{2}$ control systems should not constitute more than $1 \%$ of

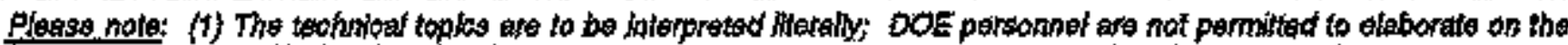

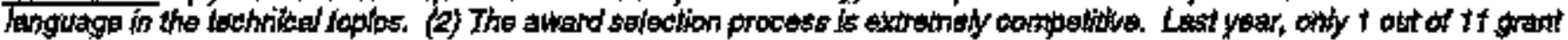

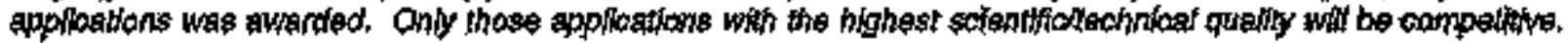


the energy input to the combustor. Parasitic energy requirements for $\mathrm{CO}_{2}$ control should be no more than $15 \%$ of the usable energy output. The system to control these pollutants individually, or in combination, must be simple to construct, operate, and maintain, and be capable of removal efticiencies of at least $80 \%$ for $\mathrm{CO}_{2}, 95 \%$ for $\mathrm{NO}_{\mathrm{X}}$, and $98 \%$ for $\mathrm{SO}_{2}$.

b. Environmental Considerations in the Recovery and Processing of Natural Gas-Grant applications are sought to develop technologies or methodologies for: (1) the management of wastes (particularly proouced water) generated during drilling, production, and processing (including waste minimization, characterization, treatment, and disposal); (2) the measurement, treatment, minimization, and disposal of naturally occurring radioactive materials (NORM) in natoral gas drilting, production, and processing; (3) the evaluation and control of greenhouse gas emissions from production and distribution operations; (4) drilling and producing naturral gas from wetlands, offshore, and other sensitive areas in an environmentally acceptable manner; and/or (5) characterization and remediation of polychlorinate biphyenyl and mercury contamination of soils associated with natural gas production operations.

c. Environmental Considerations in the Recovery of Oil-Grant applications are invited on innovative methods and concepts that allow more efficient, effective, and economic reduction of environmental risk from the primary, secondary, and enhanced oil field extraction of petroleurn. The areas of interest are: (3) techsologies for the mamagement of solid and liquid wastes generated during drilling and production, including waste minimization characterization, treatment, and disposal; (2) technologies related to the measurement, treatment, minimization, and disposal of naturally oceurring radioactive materials (NORM) in drilling and production opergtions; (3) methodologies for driling and producing oil from wetlands, offshore, and other environmentally sensitive areas in an environmentally acceptable manner; (4) environmentally safe and economically reversible plagging techniques; (5) improved methods for more cost-effective protection of drinking water aquifers, including logging techniques, well completion techniques, mechanjeal integrity testing methods, and plugging and abandonment methods; and/or (6) methodolopies for characterization and remediation of soils, and surface and groundwater contamination from produced water, drilling wastes, hydrocarbons, and other wastes associated with the oil drilling and production operations. Applications for research relating to open water oil spill cleanup technologies will not be considered.

d. Management of Coal Wastes-Methods of minimizing or atilizing coal-derived residues, especially wastes from advanced cosl combustion or conversion technologies (such as fly ash, bed ash from Pressurized Flujdized Bed Combustion, bed material from Integrated Gasification Combined Cycles, and eoal liquefaction by-products), are of interest. Grant applications are sought to develop technology: (1) to recycle the above wastes within the processes in which they are generated or to reduce the amount of waste genersted through inproved process modifications (e.g., inbed sulfur sorbents with higher capacity): (2) to utilize residues produced in fluidized-bed combustion, limestone injection nultistage burners, advanced flue gas cleaning, or gasification processes (these wastes typically have free lime or slaked lime mixed with coal ash and high $\mathrm{pH}$ which, if the waste is landfilled, may result in incressed disposal costs); and/or (3) for advanced utilization techniques tor waste from small-sized industrial boilezs. Such facilities are spread over large geographical areas, might produce waste intermittently and in relatively limited quantities, rarely have dedicated disposal facilities, and, therefore, are likely to have high disposal costs.

For (2) and (3) above, grant applications should address uses for the whole waste and not just fractions that meet specific criterie. The complexity of the equipment and machinery needed to implement the proposed waste utilization techniques should also be addressed. In the past, high copital costs have been a deterrent to the implementation of new utilization methods.

\section{Bibliography}

1. Akers, D. A and C. E. Releigh, Jr., 'A Study of the Exononnic Restraints: Uee of Advanced Coal Cleaning to Produce Premium Fuel," Contract with CQ, Ince, for the Electric Power Rege日erch Inetitute, September 1993 (EPRI Order No. RP1895-35).*

2. Clean Cocl Technologies; Research, Dewelopment, and Demonstration Program Plan, U.S. Department of Energy, Washington, DC, Novamber 199s, DOE/FE0284 (NTIS Order No. DE94004382).**

3. Crocker, M. E., et al, "Identification of Environmental R\&D Needs", U.S. Department of Energy. Wathington, 
D.C., Raport No. NIPER-430, September 1991 (NTIS No. DB91002269)***

4. Derbyehirs, F", et al, "Temperature-Staged Catalytic Coal Lifieffection," Fuel, 65(9):1289-1239, September 1986 (ISSN 0016-2361).

5. Dugan, P. R, et al, eda, "Processing and Utilization of High-Sulfur Coale TV," Procesdings of the Fourth International Conference on Processing and Utilization of High-Sulfur Coals, Idcho Fath, D, Augutst 26-30, 1991, CONF-910819, Elsevier Sctence Publisherg, 1991 (ISBN 0-444-8B268-4).

6. Economic Evaluation of FCD Systems, Electrfe Power Research Instatute, 5 Vols, EPRI CS,3942, Decomber 19 Ba (NTIS Order No. Vol. 1, DEg4920261; Vol. 2. DE84020189; Vol. 3, DE84020149; Vol. 4, TTB5920769; Yoi. 5, T187920101).**

7. Enzis, B. J., et al, "Particle Technology" The Legacy of Negleet in the U.S.," Chemleal Engineering Progresen, op. 32-42, Aorll 1994 (ISSN 0360-7275).

8. Jaeger, H. M. and S. R. Nagei, "Physics of the Granulat State," Bcience, 255:1526-1531, March 20, 1992 (ISSN 0086-6076).

9. Moron!, E. C., "Direct Cogl Liquefactiont Bridging the Gap Between $\mathbf{R}$ and $\mathbf{D}$ and Commercial Feasibility," Presented at the Amerioun Chemital Saciety National Meeting, New York, NY, April 13, 1986, CONF-690425, Preprinte of Papers - Americar Chemial Sociaty, Division of Fuel Chomistry, 81(2):340-345, April 1986 (ISSN 0669-3772),

10. Proceedings of the Fifteenth International Conference on Coal and Slurry Tocknologies, Clearwoter, FL, April dis26, 1980, Whihtngton, D.C.: Cogl and Sluny Technology Azqneistion (ISBN 0-93066-15-6).

11. Proctedings of the Seventh Annual International Rittoburgh Coal Conference, September 10-14, 1890, Pittsburgh, PA: Univereity of Pittaburgh, CONF-900958.

12. Proceedings: Tenth International Ash Uge Sympostum, American Coul Ash Aseociation, Orlando, FL, January 19s3, a Vola. (Order No. EPRI-TR-100774),*

18. Rosgart, B. J., ot al, eds, Gas Stream Cleanup Technology Status Report, DOE/METC-91/0278, Auguet 1990 (NTHS Order No. DE91002037).**

14. Srivastava, R. D, et al, "Coal Bioprocessing-A RevearchNeeds Asoensment," Chemieal Enzineeríng Prokress, 86(12):45-53, December 1989 (ISSN 0960-7275).

16. Wilson, T. D. "Knvironmentel Regulatíone for Enhanced Oil Recovery-1983 Update, "Report No. DOE/BC/10855. 1, October 1968 (NTIS No. DE84002008)."***

16. Wige, D. I., Bioprocessing and Biotreatroent of Cotl, New York: Mareel Dekker, 1990 (IBBN 0-8247-8305-0).

* Available from Electric Power Reseerch, Institute (EPRI) Order Services, P.O. Box 50490, Palo Alto, CA 94303 (Telephone 416-856-2411)

* Bee Section 7.1

\section{ADVANCED RECOVERY OF OIL}

DOE seeks innovative methods and concepts that will contribute to more efficient, economic, and environmentally acceptabile technigues for the recovery of domestic oil in declining fields. After primary (natural forces) and secondary (water flood and gas) pressurization recovery techniques have been used, approximately two-thirds of the original oil remains in place in the known producing fields - an estimated $\$ 27$ billion barrels. About 100 billion barrels of this potential resource exists as pockets of mobile oil, bypassed because of heterogeneities in the reservoir. Much of this remaining oil can be produced by conventional metheds once its location and the cause of its non-recovery are determinied. Residual oil is also susceptible to recovery by enhanced oil recovery (EOR) technjques (i.e., the injection of heat, gases, or chemicals), Better reservoir understanditis and engineering design of all of these operations (primary, secondary, and EOR) are needed to increase domestic oil production. Reservoir characterization is the most inportant means of understanding the reservoir. Its two main facets - defining the anatomy of the reservoir and detarmining how that anatomy govems fhid movement - are requisite to any tmprovements in an oil recovery strategy.

Grant applications are invited only in the tollowing subtopics:

a. Sweep Improvenent for Enhanced Od Recovery (EOR) Processes-One of the major problems in EOR sweeping processes for light oil is the control of injected fluids. Grant applications ars sought to develop methods to improve these precesses. This may be achieved, for example, by directing the injected fluid into previously unswept zones while restricting the injected floid flow into the high permeability zones (by deep plugging or by restricting flow). Both chemical and gas flooding processes are of interest. The process should not be based on profile modification or near-wellbore changes in permeability, electrical methods, in-situ microbes, chemicals produced in-situ by microbes, chemicals which are not reasonably characterized (whether or not they are produced by a chemical reaction or microbial methods), or a compater study. Novel sweep improvement agents proposed should neither be currently available from any major chemical supplier nor under patent rights to anyone other than the applicent.

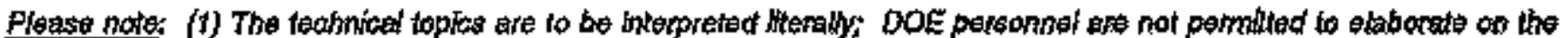
languages in tha technical topics. (2) The awart selection process is extremely conpelitive. Last year, anly f out of it gramt

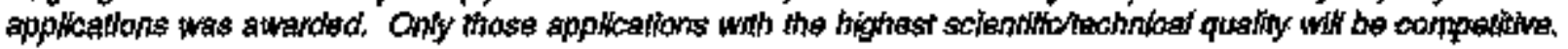


b. Novel Surtactants-The inability of most known surfactants to tolerate high salinity, high hardness, and high temperatere reservoir brines is a major problem in conducting EOR by surfactant flooding. Grant applications are sought to develop nove] surfactants which operate under these harsh condjtions. The novel surfactants should not, be based on electrieal methods, in-situ mierobes, chemicals pro. duced in-situ by microbes, chenicals which are not reasonably characterized (whether or not they are produced by a chemfeel reaction or microbial methods), or a computer study. Novel surfactants proposed should neither be currently available from any major chemical supplier nor under patent rights to anyone other than the applicant.

c. Steam Injeation Recovery of Heavy Oil-A major problem area in steam injection processes is low reservoir sweep efficiency. Grant epplications are sought on novel techniques for steam processes to: (1) improve the effective sweep of the reservoir during steam injection by reducing the effects of overriding gravity segregation, ineufficient mobility control, and heterogeneities, or (2) recover the remaining oil left in the lower part of the reservoir after steam injection has been terminated. Grant applications on improvements in reservoir sweep efficiency should not include conventionally used forns in steam injection processes. Multiple injectants, ither injected from the surface or created in situ, shonld be considered for mobility control and improved racovery.

d. Oil-Field Geoscience-A more complete understanding of the internal architecture of reservoirs, with an emphasis on the location and prediction of heterogeneities, is the kay to determining how anatomy governs reservoir fluid movement. Grant applications are sought on novel methods: (1) to characterize and quantify reservoir parameters including porasity, permeability, pore structure, capillary prossure, fracture patterns, end facies geometry; (2) to interpret depositional, diagenetic, or stmuctural features of reservairs for prediction of the spatial distribution of heterogeneities and their influence on fluid flow within known oil reservoirs; (3) to characterize known hydrocarbon reservoirs such as wellbore logeing, seismic tomography, electromagnetic tomozraphy, and three-dimensional seismic profiling; and (4) for cornputer modeling of reservoir heterogeneities and reservoirftluid interactions. Orant applications on new production equipment will be declined.

\section{Bibliography}

1. Aalund, L. R., "EOR Projects Dedine, But $\mathrm{CO}_{2}$ Pushes Up Production," Oil and Gas Journal, B6(16):33.74, April 18, 1988 (ISSN Ño. 0090-1388).

2. Bradiey, H. B., ed., Petroleum Enginaering Handbook, Richardeon, TX: Eaciaty of Petroleum Enginears, 1992 (BPE Order No. S1860).*

8. Enhanced Oil Recovery Weahington, D.C.: National Petroleum Council, 1984 (NPC Order No. LCA4061296).*

4. Gogarty, W. B., "Enhenced Ofl Recovery Through the Lie of Chemicals," Joumel of Petroloum Technology $35(10): 1581-1590$, Part 1-September 1983; 35(10):1169. 1175, Pert 2-October 1983 (ISSN 0022-3625).

5. Kretzschuar, J. L. and E. J. Witterhold, "Enhanted Recavery Survoillanee Ueing Well-to-Well Tomography", Proceedings of the SPE/DOR Fourth Symposium on Enhanced Oil Recovery, pp. 21-26, Tulsa, OK, April 16, 1984, CONF-840465, Vol. 2, Society of Petroleum Encineers AIME Paper, Vol. SPEJOOE 12680 (NTTS Na. T185005810):***

6. Laks, L. W., ot al, Resertoir Churacterization, Naw Yorkt Academilc Preas, 1986 (ISBN 0-12-434066-2).

3. Lake, L. W. et al, eds., Reseryoir Characterization Volume II, New York: Afedernic Prags, 1991 (IBBN 012-434066-0).

8. Linville, B, et al, Reservoir Charecterization III, Tulea, OK: Pent Well Publitshing, 1998 (ISBN 0-87-814892).

g. Moldnu, R. F., "Raducing Wellbors Heat Loesae", Presented at the Themal Well Complation Seminar, Edmonton, Canada, August I1, 1988, Report No. CHOA-6808, CONF-8808287.

10. Oleen, D. K. "Eetimates of Future Regional Haavy Oj] Production at Three Production Ratee--Background Information for Asagaing Fffects in the U.S. Refining Industry," JS.S. Depertment of Energy, Waahingtos, D.C., Roport Na. NIPER-606, July 1898 (NTIS No. DE93000153).*n+*

11. Prata, M., Thermal Recovery New York: Sactaty of Petroleum Enginests of AIME, 1992 (ISBN 0-89620. 314-6).*

12. Shiør, D. E., "Reconnalosenco Mepping of Straticraphic Traps in Sandetones; Deparitional Enercy Mapr and Diagnostic Maps," The Los Analyzt $80(4): 225-242,1989$ (ISSN 0024+581X).

15. Tillsan, $k$, W. and J. J. Wober, adB, Regervoir Sedimentolory, Epocial Publication, Volnene 40, Society of Econatuit Paleontologjesta and Minoralogiate, 1987 (ISBN 0-918985-69-2) (ISSN 0097-6270).

14. "The Dometic Natural Gas and Oil Initiative," U.S. Departinent of Enerey, $p_{*} 37$, Decerpber 1998 (NTTS No. DE94007230),*** 
- Ávailable from Society of Petroleum Fngineers, P.O. Box ssse96, Rlchardaon, TX 75063-8838 (Telephone 214-8529998)

* Available from National Petroleum Council, $1625 \mathrm{~K}$ Street NW, Skite 600, Washingten, D.C. 20006 (Telephone 202-393-6100)

** Ser Baction 7.1

*** Available from Alberta Oil Sande Technology and Feasearch Authority, 500 Highland PJace, 10010-106 Strest, Fidmonton, AB, CAN T5J3L8

\section{NATURAL GAS SUPPLY}

DOE Geeks innovative methods and concepts that will allow muore efficient, economical, and environmentally acceptable recovery of nabural gas. Novel improvements in recovery techniques could lead to lower production costs and/or greater recovery efficiencies. DOE's interestes in drilling, completion, and stimulation are to lower capital investment, jmprove recovery, and minimize formation damage. Collectively, these objectives are expected to reduce the unit cost of accessing and producing natural gas. The interest in low-permeability formations is to improve the detection, mapping and analysis, and gas production of naturally fractured gas reservoirs for economic recovery. The interest in gas delivery and storage is focused on assisting the storage industry to develop, test, and improve new or existing technology for improved storage system eapacity and deliverability as well as to assist and provide the gas storate industry more accurate and timely information on the natural ges pipeline/storage system network. The interest in natural eas uperading is in sonverting methane to liquids or chemicals in a simple one- or two-step process under moderate operating conditions of pressure and temperature, and advancing processing tachnologies for raising low-quality raw natural gas to pipeline quality.

Grant applications are iuvited only in the following subtopics:

a. Drilling, Completion, and Stimulation-Innovative approaches are desired to reduce the cost of drilling gas wells while improving or maintaining safety, and minimizing environmental disturbance. Grant applications are sought for technologies, systems, and methods which: (1) increase the rate-ofpenetration, (2) provide timely, accurate geologic and drilling information, (3) result in new tools for cutting medium-to-hard, abrassive formations, (4) enbance horizontal well, slimhole, and underbalanced drilling technology, (5) minizuize stimulation fluid damage, (6) introduce and demenstrate novel stimulation con. cepts, sad/or (7) develop new or improved completion hardware.

b. Low-Permeability Formations-Research has shown that gas production from low-permeability "tight" gas reservoirs is dependent on the presence of natural fracture systems for economie production. The use of horizontal or steeply inclined boreholes to incresse production from these reservoirs is dependent, upon the knowledge of fracture systems and their orientation for proper drilling design and stimulation. Grant applications are sought for innovative methods to identify, locate, and orient these frachure systems so that recovery of gas froml low-permeability ( $<0.1 \mathrm{mi}$ )lidarcy) reservoirs can be improved. These innovative techniques/methodologies include: (1) high-resolution seismie techniques to locate naturally fractured reservoirs, and (2) improved gealogical and geophysical methodologies for mapping, prediction, and analysis of noturally fractured gas reservoirs.

c. Delivery and Storaso-Gtant applications are sought for innovative and cost effective methods to improve the deliverability and the capacity of the netural ges storage reservoirs. Topics of interest include: (1) cost-effective improved storage capacity for industrial/power generation users in areas of high demand, (2) new or improved methods to revitalize deliverabjility from existing storage wells, (3) methods to optitivze new or infill storage field development, (4) cast effective methods to reduce gas migration in problem fields, and (5) cost effective methods to reduce gas trapping in aquifer storeger.

d. Natural Gas Upgrading-Domestic supplies of natural gas are abundant. However, some natural gas resources are remote from gas transportation systems or contiain lerge amounts of nonmethane gases which make them uneconomital to market as naturel gas. The ability to convert these remote and potentially lowvalue gases to high-vahue liquids or to remove the nonmethane impurities could have significant favorable economic and energy efficiency impacts. Grant applications are sought for innovative technologies to convert natural gas to liquid fuels and to raise low. quality raw natoral gas to pipeline quality. Regarding natural gas conversion to hquid tiels, interest, is in

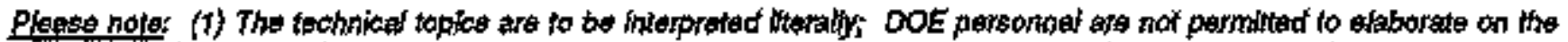

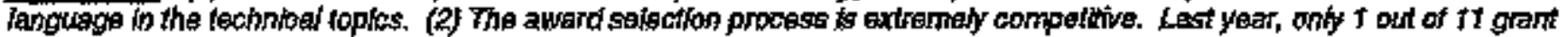

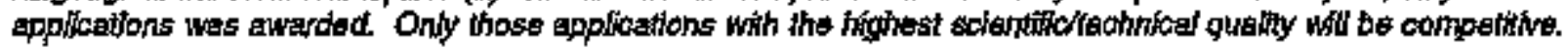


simplified processes for producing specialty chemicals or higher value hydrocarbons directly and in new or improved separation tochniques to remove desired products from unconverted feedstock. Regarding the raising of low-quality raw natural gas to pipeline quality, techniques using small scale facilities are sought and include: membranes, absorption/adsorption, and/or hybrid combinations of these technologies. With respect to the removal of hydrogen sulfide from natural gas, the techniques sought must also encompass its subsequent or direct conversion to elemental sulfur or other environmentally benign products.

\section{Bibliography}

1. Frahne, K. H. and C. A. Kornar, eda, "Wagtern Ges Sends Technology States Report, "DOEAETC-89/0284, January 1989 (NTIS No. DE99000948).*

2. Gwilliam, W. J., "Deep Source Gas: Technolagy Status Report," DOEMETC-9010271, April 1990 (NTTS Order No. DE90015320 XAB)*

3. Komgr, C. A., "Unconventional Gas Resources: Avaj]able Pablications Liating," May 1983, DOEMC/L92591295 (NTTS Order No. DE83012852).*

4. Layme, A. W, and A. B. Yast II, Development of Advanced Drilling, Completion, and Stinulation Eystame for Minimurn Fornation Damege and Improved Efficiency: A Program Overview," Proceedings-SPE International Symposium on Formation Domage Controt, pp. 162-169, 1994, Society of Petroleurn Enginars (Order No. SPEDOE 27869).**

6. Malone, R. D., "Gas Hydratest Technology Status Report," DOEMETC-90/0270, April 1990 (NIIS Order No. DE90015321)*

6. Malone, R. D. and C. A. Komer, eds., "Natural Gas To Liquide Technology Status Report," DOEMETC. 890265, Jantary 1989 (NTIS Order No. DE89000982)."

7. Malone, R. D., Procesdings of the Fuels Technology Contractars Review Mesting Conference, Morganfolon, WV. Noutmber 16-18, 1993, CONF-932156, Report No. DOENETC-92/6125 (NTIS Orter No. DE94004065).*

8. 'Natural Gas Strategic Plan and Multi-Year Program Crasscut Plan, FY 19941990" U.S. Department of Energy, p. 319, Decenter 1993, Report No. DOE/FE0297P (NTIS No. DE94008819).*

See Section 7.1

** Availabio from the Society of Petroleum Engineere, P.O. Box 832836, Richardaon, TX 75083-3836 (Teleptrone 214962-9393)

\section{NATURAL GAS UTILIZATION}

DOE is funding efforts to develop and demonstrate advanced technologies for the utilization of natural gas. Programs are underway to develop both advanced gas turbine systems and fizel cells for high efficiency production of electricity from natural gas. Successful commercialization of these advanced technologies will reduce national fuel use because of improved efficiency, while providing benefits to the U.S. environment and economy. DOE is interested in innoyative research to support these devolopments. Grant applications are invited only in the following subtopies:

\section{a. Advanced Turbines Componento-Grant} applications are sought for the development of novel components for advenced, ultra-high-efficiency gas turbine power systems and for the improvement of existing components. Component innovations must support the development of advanced power systems under the DOE Advanced Turbine Systems program (References 5 and 7). They should either contribute directly to the achievement of program goals or offer promise to provide improved performance in the time following initial commercialization. The innovations may address requirements for initial natural gas-fired systems or requirements for eventual adaptation of the systems to coal.

b. Thermodynamics of Advanced TurbinesGrant applications are sought to develop advanced thermodynamic cycles or cycle improvements to increase system efficiency in support of the Advanced Turbine Systems program (References 5 and 7). These efforts should either contribute directly to achieving program goals, offer promise to provide improved performance later, or contribute to system adaptation to coal-firing.

c. Molten Carbonate Fuel Celts-Molten carbonate fuel cell technology is important for stationary electric power generation. Grant applicstions are sought to develop novel designs and materials which can provide lower stack cost, longer operating life (lower decay rates), and improved performance (higher power density).

d. Solid Oxide Fuel Cello-Stationary power generation can also benefit from advancements in solid oxide fuel cell technology. Grant applications are sought to develop novel designs and improved 
materials which can result in improved performance (lower internal resistance), longer operating life (lower decay rates), and lower stack cost.

\section{Bibliography}

1. Appleby, A. J. and F. R. Foulkes, Fuel Cell Handbook, New York: Van Nastrand Reinhold, December 1989, revised 1992 (ISBN No. 0-442-81926-6).

2. "Fuel Cel] Seminar, Program and Abstracts," Procerdings of the 1992 Fuel Cell Seminar: Fuel Calls. Rtalizing the Potential, November 29.December 2, 1992, Washington, D.C.: Courtesy Aseciates, Inc., 1992 CONF-921114 (NTIS Order No. DE94008882)."

a. "Fuel Call Syetemi Program Plan, Fiscal Year 1998," U.S. Department of Energy, Asejetant Secretary for Paneil Enercy, Report No. DOEFB0200, 1993 (NTTS Order No. DE93017828).*

4. Geiling, D. W, ed, Procesedings of the Joint Contractors Meting: FE/ EE Advanced Turbine Sysams Conferencr. PE Fuel Cells and Conl-Fined Heat Engines Confenence, U,S, Department of Energy, Washington, D.C., Augut 1993, DOE Report No. DOEMETC-98/6132, CONF. 980698 (NTI8 Order No. DE908011308).*

5: Hirechenhofer, J. H., et al, Fuel Cells, Handbook (Rovision 3) U.S. Department of Energy, Offee of Foseil Fnergy, Januery 1994, Report No. DOEMETC-941006 (NTIS Order No. DE94004072)*

6. Hooie, D. T., ot al, Fuel Cella: Technical Status Report," Report No. DOEMETC-92/0276, July 1992 (NTIS Ordar No. DEg2001282).*

7. "Report to Congresa: Comprehensive Prozram Plan for Advaread Turbine Bystems," U.S. Department of Bnercy, Washington, D.C., July 1993, Report No. DOENE.0279 (NTIS Order No. DE93016718),*

8. Webb, H. A, and W. P. Parks, "Program to Develop Advanced Gas Turbine Systerss," pressented at Air and Worle Management Assactation Annvol Meeting, Cincinnatt, Ohto, June 29-24, 1994, Report No. DOEMMTC/C947182 (NTIS Order No. DE94014673).*

* Eas Section 7.1

\section{ADVANCED COAL-BASED POWER SYSTEMS}

The DOE is supporting the development of new, coalfired power plants based on advanced pulverized coal technology with the potential for high efficiency, low emissions, and reduced cost relative to today's coalfired generating plants. These systems include ad- vanced pulverized coal combustion with both directand indirectly-fired cycles, integrated gasification combined cycle (IGCC), and pressurized fluidized bed combustion (PFBC).

In contrast to direct oal firing, in indirectly-fired cycles, heat released from cosel sombustion is transferred across heat transfer surfaces to the gas turbine working fluid (e.g., eir) as it passes through the compressor section of the turbine, increasing its temperature to a level limited by system design characteristies and materials capabitities. Further heating of the working fluid, if needed, occurs through direct firing of a clean supplemental fuel in the gas turbine combustor in order to take advantage of modern gas turbine inlet temperatores. After expansion through the turbine, part or all of the turbine exhaust is used for the combustion of coal. Energy remaining in the coal flue gas (and in the gas turbine exhaust not recycied to the coal combustor) is exiracted via a steam bottoming cycle. The success of the system depends in part on the abitaty to effectively and economically transfer heat to the worktng fluid while minimizing degradation of the high temperature heat transfer surfaces.

In an IGCC system, coal is converted into a gaseous fuel, which, when cleaned, is comparable to natural ges. The fusel gas, composed of hydrogen and cerbon oxides, is generated in a gasifier when coal reacts with steam and air or oxygen. Over 99 percent of the coul's sulfur and particulate contaminants are removed before the fuel gas is borned in a high-efficiency combustion gas tortbine/generator. The hot turbine exhaust gas produces steam to drive a steam turbine genterator. Today, six state-of-the-art 1GCC technolo. gies are in various stages of commercial demonstration with expected installation costs of $\$ 1,500$ to $\$ 2,000$ per kilowatt and with plant efficiencies around 40 percent. DOE seeks to achieve plant efficiencies of 45 percent and 52 percent, and capital costs of $\$ 1,200$ and $\$ 1,050$ per kilowatt, by the years 2000 and 2010 , raspectively. If these goals are achieved, IGCC investment could exceed $\$ 150$ billion by the year 2030 .

PFBC systems have several inherent advantages over conventional pulverized-coal power systems. High system efineiency results from the combined-cyele configuration, which includes a conventional steam cycle and a gas terbine. Limestone or dolomite mixed with coal in the fluidized-bed removes the coal's sulfur, eliminating the need for post-combustion tlue gas

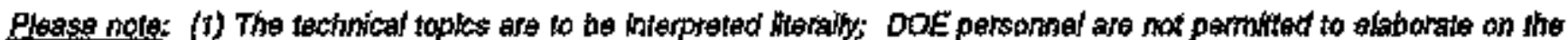

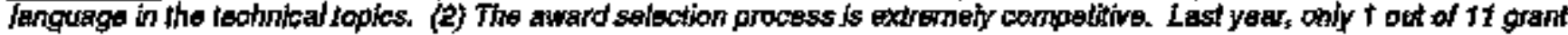

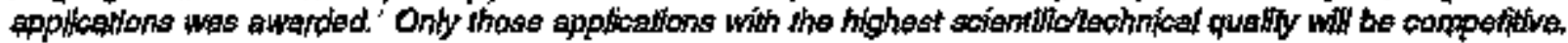


desulfurization. Lower combustion temperatures and air staging reduces the amount of nitrogen oxide emissions. Ceramic filters are used to clean the hot gases from the pressurized fludized-bed combustor and partial gasifiers that are incorporated into higherefficiency advanced PFBC systems. The ceramic filters ensure that turbine corrosion/erosion/deposition requirements and environmental enissions limits are met. Fluidized-bed combustion systems also produce a dry ash by-product that can be beneficially reuged. PFBC technology is on the brink of commercialization, with five principal firms developing first-generation PFBC power systemis capable of net system efficiencies approaching 42 percent with installation cost expectations ranging from $\$ 1,800$ to $\$ 2,000$ per kilowatt. DOE seeks to achjeve PFBC system efficiencies of 45 and $\$ 2$ percent, with capital costs of $\$ 1,100$ and $\$ 1,000$ per kilowatt by the years 2000 and 2010 , respectively. If these goals are achieved, PFBC investment could exceed $\$ 400$ biltion worldwide by the year 2080 .

All of these coal-based power systems require materials and components capable of withstanding high temperatures and corrosive environments. of particular interest are products that would improve system economics via enhancements to the capabilities/ economics of materials used within these systems. Areas of interest include both alloy and ceramic materials used to contain working flutids such as high temperature air and supercritical steam.

Grant applications are invited only in the following subtopics:

a. Advanced Pulverized-Coal Power SystemsCoal-fired burners, integrated burner systems, and critical components have potential application to advanced pulverized-coal power systems including indirectly-fired cycles. Grant applications are sought to develop: (1) advanced combustion control diagnostics which provide continuous on-line measurement and control of the fuel and air flow rates for each burner, or at specific locations in the boiler or coal combustor; (2) low temperature heat recovery systems or systems integration schemes for using low-grade heat from the flue gas to econornically increase power plant efficiency; (3) scientifically hased computational tools for design and performance ana)ysis (applications may include improvement of existing codes or development of tools which address mitigation of coalash related problems, minimization of emissions, efficiency of fuel use, heat relesse patterns, and heat transfer); and (4) critical components for use in advanced cycles (supercritical steam cycles and variable-compasition working fludd cycles - bumid air turbine cycle, and Kalina cycle), including pressurized hish-temperature ceramic heat exchansers (including structural support designs and high pressure seals), novel high-pressure water injection systems, and direct evaporative coolers for advanced water-augmented indirectly-Gred gas turbine systems.

The combustion systems may operate in mither a slagging or non-slagging mode and must exhibit enhanced overall system performance (lower capital, operating, and maintenance costs) relative to conventional low-NO $\mathrm{N}_{x}$ burmers, with substantially reduced NOx emissions and a high level of carbon tutilization.

b. Integrated Gasification Combined Cycle Systems-Grant applications are sought to develop; (1) novel, effective, economic, and efficient processes and/or devices fot removal of physical and chemical contaminants independently or in combination from coal gasification streams to levels that meet gas turbine and/or environmental emisssion requirements, (2) novel systems to decompose ammonis in IGCC fuel gas streams and/or to cleanly comburt fuel gas with minimal $\mathrm{NO}_{\mathrm{x}}$ production, (3) innovative low cost and reliable systems for sulfur removal from the pres. surized IGCC fure] gas at high temperatures (i.e., above the dew point of the gas), (4) novel low cost technolo. gies to produce sulfur byproducts in conjunction with high temperature sulfur removal, (b) systems for monitoring, characterization, and control of air toxics in IGCC pas streams, (6) novel low cost, long life barrier filter systems for high pressure, high tempera. ture particulate removal in IGCC gas streams, and (7) improved instramentation and components suitable for IGCC high pressure, high temperature gas streams.

\section{c. Pressurized Fuidized-Bed Combustion} Systems-Grant applications are sought to develop: (1) critical components such as more effective piping systems for high-ternperature, high-pressure gas streams with high-solids contents, valves used to control the transfer of hot bed material, and coal/water paste feed pumps; (2) novel gas turbine compatible fuel gas combustion systems that can boost gas teniperatures entering the gas turbine into the $2,600^{\circ} \mathrm{F}$ range with minimal NO production; ( $\$$ ) systems for monitoring, characterization, and control of air toxics in PFBC gas streams; (4) novel low-cost, long-life barrier filter systems for high-pressure, high-temperature 
particulate removal in PFBC ges gtroems; (5) devices for simultanetously removing particulates and chemical contaminants independently or in combination to lovels that meet gas turbine and/or environmental emission requirements; and (6) novel concepts and equipment configurations that allow the furel-flexible nature of fluidized-bed combustion systems to reduce operating costs through the introduction of opportunity fuels (such as high sulfur coal, petroleum coke, and municipal waste sludges) and/or sorbents.

d. Materials and Components for Coal-Baspd Power Systems-Crant applications are sought for: (1) new structural ceramics and alloys including ceramic composite inaterials, nanocluster ceramics, advanced austenitic alloys, iron ahuminides, and ultrahigh temperature intermetallic alloys; (2) novel manufacturing/production techniques that would significantly reduce the cost of a material used in a coal-besed power system (of particular importance is the incorporation of these advanced materials into noar-net shape components which solve a critical problem in coal-based power systems, as opposed to the general assessment of a new material combination using coupon testing); (3) new costings or other meterial formulations with improved high-temperature strength/corrosion resistance/economics relative to materials currently evailable or in development (appli. cations in this area must focus on specific solutions to known corrosion mechanisms which lead to metexial degradation in the hitghly corrosive environments of coal-based power systems); (4) novel design tools/ methodologies for the mechanfeel design of hoghtemperature heat transfer surfaces; and (b) improved techniques for joining ceramics to ceramies and ceramics to metals.

Grant applications are also sought to develop: (1) solid-stats electrolytes for eneroy conversion, gas separation systems, and electrochemical reaction systems; and (2) functional materials for inorganic porous/nonporaus systems that would be used in gas separations including ceramic filters for hot gas clegn-up.

\section{Bibliography}

1. Hajura, R. A., and H. A. Wobb, Ths Marriage of Gas Turbines and Coal," Mechenicel Enginesing, Pp. 68-68, Eaptember 1991 (ISSN 0025-6501),*

2. Bonk, D. L., Procedings of the Coal-Fired Power Syatems 98: Adunced in IGCC and PFBC Revielo
Meeting, Morgantoun, WV, June 1998, (NTIS Ordar No. DE93000289)**

8. Goilting, D. W, Procesdinge of the Soint Cantractore Mesting: FE/EE Advanced Tutbins Systemus Conference FE Fuel Cells and Coal-Fined Hoat Engtines Conference, Morgantown, WV, August 199s, (NTTS Order No. DE93011309).**

4. LaHaye, P. G, and M. R. Bary, "Externally Fired Combustion Cycle (EFCC): A DOF Clean Caal V Project," International Gas Turbine and Akroangine Congress and Rxporition Conference, The Hasus, Netherlands, June 18.16, 1994, CONF-947271 (NTIS Onder No. DE94014671).**

b. LaHaye, P. G, and E. Zabolotny, "Externally-Fired Combined Cycle (EFCC)," Procesdings of the ASME 3rdinternational Symposium on Turbamachinery, Combined.Cyale Technologies and Cogeneration Meeting, Nice, France, August 80 - September 1, 1988 , pp. 263-274, CONT-890BA8.

6. Orozen, N. Jo "High Preseure Ceranite Air Heater for Indirecthy-Fired Gas Turbme Applicetions, "Proceedinge of the Joint Contractors Meeting - FE/ER Adpanced Turbine Systems Conference - FE Puel Cells and Coal. Fined Hant Engines Conference, Morgantaton, WV, Augugt 3-6, 1993 (NTS Order No. DE98011908),"*

7. Proosedinga of the Becont Annual Clean Coal Technalagy Conference, Atlanta, GA, September 7.9, 1998, V1, U.S. Department of Energy and Southern States Enorgy Boerd, CONF-999162 (NTIS Order No. DE94004478)."*

8. Rubow, L. N., ed., Proceedings of the 12th Intemotional Conforence ont Fluidized Bed Combustion, San Diego, CA, May 9.13, 1998, American Soojety of Mechanianal Engineort (ISBN 0-7918-0679-0).

9. Seery, D. J., "Combuation 2000: An Approach to Burning Coul in the Twenty-Firgt Century, "Proceedlings of the Tenth Annual International Pitteburgh Coal Conforence, Unilerstity of Pittsburgh, Pittsburgh, PA, Septamber 20-24, 1993, PP. 490-495 CONP-1909111.

10. Shenker, "Development of a High-Performanes CoalFired, Power Generating 8ystern with a Pyralysie Gas. and Char-Fired High Temperature Furnace," Procedings of the Ninth Annutal Coal Proparation, Ditlieation and Environmental Control Contrwetors Conference, Pittaburgh, PA, September 1993, pp. 949356, CONF.980787 (NrSS Order No. DES9019830), th

11. Takemeter, T. and C. Maude, Coal Geafication for ICCC Powrer Generation, IEACR/37, March 1991 (ISBN 92-9029.190-7).

12. Vandervart, C. I, at al, "Externally-Fired Combined Cycte Repowering of Exieting Sterm Planta," International Gat Turbine and Aeroengine Congress and Exposition Conference, Cincinnati, $O H$, American Society of Mechatrical Engivesers, Neav York, NY, May 24-26, 1993, pp. 1-8:93-GT-369 (ISBN 0402-1215).* 


\footnotetext{
* Availablo from American Society of Mechanical Engineers, 345 East 47th Street, New York, NY 10017 (Telephone 800-843-2763)

** See Section 7.1
}

\section{ADVANCED FOSSIL FUELS RESEARCH}

Though coal is our most abundant and inexpensive fossil fuel, the release of clean energy from coal requires the solution of many problems in processing, transport, and conversion. The results of novel approaches and innovative research could contribute to greater utilization of our fossil resources. Grant applications are invited only in the following subtopies:

a. Coal Preparation-Coal preparation processes are used to pretreat or modify coal to provide a fuel appropriate to various applications. These processes include removal of ash-producing minerals such as pyrite, trace elements, sulfutr, and nitrogen through physical, chemical, biological, or combined methods. New process concepts, or improvements in existing protesses, can enhance beneficiation technologies and $/$ r the handiling and marketability of coal through physical, physicochemical, chemical, or biological means. Grant applications are sought for advances in the following processes: (1) comminution, surface- or denstity-based cleaning, dewatering/drying for either low or high rank coals, reconstitution, and enhanced energy recovery through applications of high technology instrumentation; (2) optimization programs for coal preparation, including hardware (i,e., advanced sensors, controllers) and software (i.e., advanced diagnosties, algorithms) that support artificial intelligence and neural networks in the whole plant or iz or unit operations within the plant; and (3) chemical or physicochemical coal treatment and/or biological methods for dechlorination, desulforization, and denitrification.

b. Recovery and Processing of Coal Fines-It is estimated that millions of tons of caal fines (minus 28 mesh) are being incounded annually in the United States as waste material from coal preparation plants. Approximatoly 40 million tons of raw fine coal are produced just in the eastern U.S. Environmental and econotic benefits that may be obtained from utilizing these coal fines include limiting the amount of coal waste sent to storage ponds and providing a potentially low cost fuel. Grant applications are sought to develop technologies for the recovery, processing, and combustion of coal fines that are now being generated as waste products from cosl preparation plants. Grant applications should identify novel approaches to converting specific coal fines waste stream(s) into a fuel form that can be utilized alone, or in cornbination with other fuels (e.t., industrial wastes and/or biomass).

c. Solids Transport-Large amounts of coal are transported and processed each year, and significant amounts of money and energy are spent for these operations, Coal and other solid materials such as ash, sorbents, and catalysts are handled in many plants producing or using coal-based foels (including coal preparation plants, industrial and electric utility plants, and liquefaction or other processing plants) in the bulk eranular phase, dense pneumatic phase, or slurry phase. Knowledge of these flows is less mature than that of single fluid flow, and this lack of knowledge limits the effectiveness in handling bulk solid materials. New developments in sobid transport technologies, including measuring and monitoring devices, will help to elucidate the basic characteristics and dynamics of these flows, improve the existing methods of handling solid materials, and reduce transport and processing costs. Grant applications are invited to develop: (1) novel, industrial-style jnstruments and devices that can diagrose, monitor, or control these granular, dense pneumatic, or shurry flows (parameters of interest include. but are not limited to, mass flow rate, solid concentration and velocity, and agglomerations of solid particles); (2) advanced control software that can improve the stability and reliability of the solid transport processes; and (3) new concepts and improvements for lowering attrition in dense pneumatic systems or for moving bulk solids over long distances with low energy consumption and low cost. The proposed effiorts should be applicable to the specific flows found in fossil energy transpert processes.

d. Conversion of Coal and Oil Products-liquefaction refers to the direct hydrogenation of coal to produce bquids and to the production of liquids from synges produced by coal gasification. Heavy oil processing refers to the upgrading of difficult to process heavy petroleurn residuums via coprocessing with coal or other hydrogen addition and carbon rejection processing techniques. Grant applications are sought 
to develop: (1) innovative reaction concepts and catalyst systems (fixed-bed or disposable) to promote more efticient conversion reactions (the emphasis is on gignificant process cost reduction and may include novel approuches for gainine additional knowledge of reaction chemistry as we]l as novel biological approaches); (2) novel methods for improving mild gasification of coal resulting in more valuable upgraded liquid and solid fuel products, lower costs, and/or improvement in environmental performance; and (3) innovative processes for the production of synthesis gas and/or hydrogen from coal (these processes may involve reactor concepts, catalysts, biological processes, and the separation of solfur, nitrogen, and/or trace contaminants from coal gas streams). Grant applications on incremental improvements of conventional technology and minor modifiegtions of prior work will be declined.

\section{Bibliography}

1. Derbyehirs, F., et al, "Tempperature-Staged Catalytic Coel Liquefaction, Fuel, 6o(9):1288+1299, September 1086 (ISSN 0016-2961),

2. Dugan, $\mathbf{P}, \mathrm{B}_{\text {, }}$ at al ade, Processing and Utilization of High-Sulfur Coals TV," Proceedings of the Foturth International Conference on Processing and Utitization of High-Sulfir Coals, Idaho Balls, ID. August 26-30, 1991, CONF.910019, Elevier Seience Publighers, 1991 (ISBN 0-444-88263-4).

3. Ennit, B. J, ot al, "Particle Technology: The Logecy of Neglect in the U.S.," Chepnical Engineering Progrese, V90:N4(92-42), April 1994 (ISSN 0360-7275).

4. Joeger, H. M. and S. R. Nagel, "Phyates of the Granular State," Science, 256:1525-1591, March 20, 1992 (19SSN 0086.6075).

5. Moroni, E. C., "Direet Coal Liquefaction: Bridging the Gap Between R\&D and Commerctel Feasibility," Amerzcan Chemical Bocisty National Heeting, New York, NY, April 19, 1986, 31(2):340-345, April 1988, CONF-860425 (ISSN 06693772 ).

6. Proceedings of tho Fifteenth International Conferencs on Coal and Sturry Technotogies, Clearoater, FL, April 28. 26, 1990, Washington D.C.: Coal and slurty Technology Ansociation (ISBN 0-98066-15-5).

7. Proceedings of the Sewenth Annual International Pattsburgh Coal Conference, September 1990, Pittsbugh, PA: University of Pittsburgh, CONF-900958.

g. Srivactaven, $R_{m} D_{\text {r }}$ at al, "Coeal Bjoprocessing - A Reeearch - Needs Aesessment," Chemical Engineenng Progress 85(12); 45-53, December 1989 (ISsin 03607275).

9. Wles, D. L., Bioprocessing and Biotratment of Coal, New York: Marcel Dekker, 1990 (ISBN 0-8247-8305-0).

\section{IMPROVED TECHNOLOGY FOR OBTAINING RECYCLABLE MATERIAL FROM MUNICIPAL SOLID WASTE}

\begin{abstract}
Although landfilling is the most common waste management option, most states and many communities have set goals for diverting muniejpal solid waste (MSW) from landfil]s. These objectives are generally expressed as material recycle goals. A major obstacle to achieving these goals is the cost of collecting and/or separating potential recyclables from the MSW and preparing them as marketable secondary materials. Also, current practice often uses manual labor to conduct the sorting. Generally, the cast of recovering the material exceeds the cost of similar virgin materials. Innovative technology is needed that will reduce these costs and/or minimize the manua] labor for generating marketable secondary materjals.
\end{abstract}

Recycling/waste control/processing is identified as one of the national critical technologies in the area of energy and environment. MSW is a source of clean energy, but, if not properly treated, will continue to be an environmental burden in the fubure. Grant applications are invited only in the following Eubtopica:

a. Collection-Studies have shown that collection of recyclable materials at the curbside is usually the most expensive step. Costs of $\$ 90$ and $\$ 150$ per ton collected have been published, and some large cities have reported curbside collection costs of over $\$ 200$ per ton. In spite of the economic burden, curbside collection is the approach used at the community level. Current costs greatly reinforce the need for new commercial altematives that the community can readily adapt to its specific needs. Grant applications are sought for innovative collection technology that could signifieantly decrease costs without compromising the quality and quantity of recyclable materials. Grant applications must address one or more of the factors which effect cost: crew size, productivity, extent of material separation, and vehicle and equipment requirements.

b. Material Separation and ProcegeingRecyclable materials collected at the curbside are processed in a material recovery facility (MRF). MSW, or the materials left after curbside collection, is

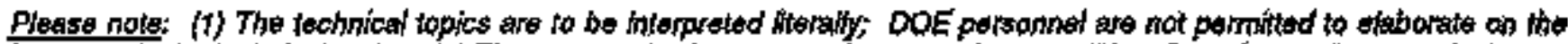

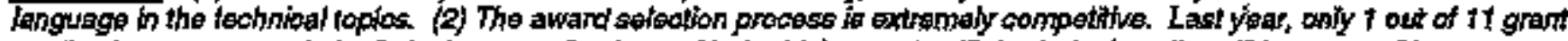

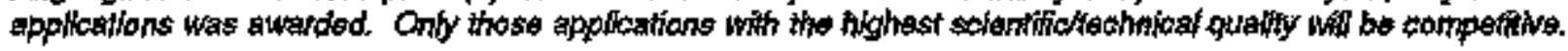

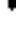


processed in a mixed waste MRF. Either method, MRF or mixed waste MRF, adds signifjcantly to the cost of preparing recyclable material for the secondary material markets. Average costs of $\$ 50$ per ton processed have been published. The quality of the secondary materials often limits markets. Also, manual labor is often required to reach satisfactory level of secondary material quality. Grant applications are sought to develop innovative methods for material separation and processing which reduce the need for manual separation and reduce the total cost. Possible approgehes could include mechanical separation, coding, sensors, or new uses for secondary materials that can readily be scaled to the commercial level.

\section{Bibliography}

1. "Composition and Properties of Munjeipal Solid Waste and Its Components," Cal Recovery Systems, 101 pp., May 1984 (NTIS Order No. DE84011898).*

2. "Data Summary of Municipal Solid Wasta Management. AJternatives," 66 pp., Oetoher 1992 (NTIS Order Na. DE93008810)* *

3. Gavette, K. B., The Inpact of Source Soparation on Municipal Waste-to-Energy Project Feasibility 70 pp.s 1989 (NTYS Order No. DEs9013853).*

4. Mayberry, J. L., Municipal Waste Procoseing Apparatuk, " 6 pp.; September 19, 1989, US. Departanent of Energy, (Patent No. US 4867866) * *

5. Miller, C., "The Cost of Recyreling at the Curb," Waste Axe, V24:10(48-64), October 199a (ISSN 0043-1001).

6. Miller, C., "The Real Price of Processing," Warts Age V2s:(10), Ostubar 19, 1982 (ISSN 0043-1001).

7. Muitifamily Recycling Programs: Program Data and Implementation Guidelines," 130 PP., September 1992 (NTIS Order No. DE98006609).*

8. Rabagca, L., MRF of the Manth: Automation Inereages Capacity at Florida MRF," Wagte Age, V24:461); April 1998 (ISSN 0048-1001).

9. Riding, R. L., and C. Broroks, "Love Technology Rebource Recovery: Source Separation," "Energy from Mubicipal Wastes: Opportunities for the Southwest," Argonne National Laboratory Report ANLCNSV.TM-173, CONF. B806394, 44 pp., May 1987, (NTIS Order No. DE87014258).*

10. Wolsky, A. M, et al, "Paradoxon of Cleaning Up the Environment: Regulation end Recyeling," Report CONF. 8710280.1, Axgonne National Laboratory, 44 pp., Oetober 4,198 ? (NTIS Order No. DE88006007).*

\footnotetext{
* See Section 7.1

** Avejlable from the Conmissioner, Patent and Trade Mark Office, Box 9, Washington, D.C. 20281
}

\section{LIGHTWEIGHT COMPOSITE MATERIAL FOR AUTOMOTIVE STRUCTURES}

One of the missions of the DOE is to develop new and emerging technologies that promote the conservation of petroleum products. This goal is often coupled with a need to reduce environmental pollution by waste minimization or recycling efforts. Petroleum products find their greatest use in the transportation industry where automobjles currently account for just under two-thirds of the Nation's gasoline consumption and gbout one-thitrd of the total U.S. energy usage. Since $75 \%$ of a vehicle's fuel consumption is directly related to factors assaciated with its wight, reducing the weight of future autiomobiles and the components comprising vehicular structures is critical to reducing domestic oil consumption.

Because of their high strength to weight ratio, composite materials have the potential for reducing vehicle mass without sacrificing passenger safety or comfort. However, several technologica] hurdles must be overcome before composites will see wide scale use in the logd bearing structures of automobiles. Grant applications are invited only in the following subtopies:

a. Processing and Production of Low Cost Glase Fiber Preforms-The manufacture of composite materials often requires the use of preforms made of inexpensive glass fibers. These preforms are used to make liquid molded [Structural Reinforced Injection Molding/Resin Transport Molding (SRTMATM)] composites. Grant applications are sought for now processing technologiss which will allow for an increase in the production rate of large glass preforms, and provide significant cost reductions in the resultant glass fiber preforms. The Phase II project should culminate in a prototype demonstration and show a peth to commercialization.

b. Liquid Composite Molding TechnologyLarge structural components for future automobiles may be molded in one piece to reduce assembly costs and production line start-to-finish times. In order to form large structural automotive parts, liquid composite molding (SRIMRTM) technologies are expected to be employed where a reactive hquid resin is injected into a closed mold containing a preform 
which would most likely consist of glass fibers. Grant applications are sought to develop molding process tochnologies, includ-ing mold and part designs, which are both rapid and cost effective. Grant applications should consider opportunities and restrictions inherent in the use of glass fiber preforms and the liquid molding process, address both mold and part desigm, and should involve polymer based composite materials. The Phase II project should culminate in a prototype demonstration and show a path to commercialization.

\section{a. Durability Characteristice of Light Weight} Composite Structures-Steel has been well characterized in a wide variety of environments to which it is subjacted over the life of an automobile. One of the major barriers to the use of composite materials in antomotive structures is the uncertainty of their response over long periods of time in a variety of climates and conditions. Grant applications are sought to develop test methods to evaluate the durability of automotive composites over a vehicle's life span while subjected to the same stresses and environmental conditions as current automobiles. Materials to be evaluated must be light weight polymer-based composite structures made from high volume manufacturing processes. By the end of Phase $\mathrm{I}$, the test methods znusti be proven using potential automotive composite materials.

d. Test Methods for Structural Adhesive Joints-A aritical aspect of using composite materiais is the manner in which they are joined. Adhesive bonding is potentially an economical and structurally sound means of joining reinforced polymers and other alternative automotive materials and may overcome a major obstacle to the incorporation of polymer composites into automobjles. The automotive industry does not currently have a complete set of processes and methods for evaluating candidate adhesives, adherents, and their interactions for use in bonding structural antomotive composite components. Grant applications are sought to develop test methods to evaluate the ability of an adhesive joint to resist fracture, ereep fracture, fatigue, fatigute fracture, impact loading, and onvironmental degradation. Grant applications must develop and validate the test methods with multiple composite/adhesive combinations.

\section{Btbliography}

1. Hamade, T. A and R. D. Wharfield, "Automotive Bxtorior Body Panels with Polyurea and the Reaction Injection Mfolding Procees," Propessint of Polymurs "ind Polyrentic Composites, Proceedings of the Winter Annwal Mepting of the American Saciety of Mechanical Engineer, Dallas, TX, November 25-30, 1990, V19(717) 1900 (ISBN 0-7918-0560-8).

2. Hunt, Mergaret, "Beyond Magje: Carsietent Cast Composites," Materiala Engineering, V108:N1(21-24), Janttary 1991 (ISSN 0025-6819).

8. Liechti, K. M., and T. Freds, "On the Use of Laminated Beams for the Determination of Pure and Mfxed-Mode Fracture Propertieb of Struetural Adhesives," Jourmal of

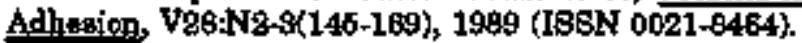

4. "Materials Sciance and Enginesring for the 1900's: Meintaining Compotitivenese in the Afe of Materials," National Research Council, National Academy of Science Press, 1969 (ISBN 0-3090-3920-2/0-3090-3894-4).

5. Warren, C. D., at al, "Adhegiva Pondìne of Polymeric Materials for Automotive Applications," Proceedings of the Annual Automotive Technalogy Deselopment Contrackar's Coordination Mesting, Dearborn, MI, Ocfober 1993, pp. 1-11 (ISBN 1-56091-539-0).

\section{HYBRID ELECTRIC VEHICLE TECHNOLOGY}

New fechnology needs have been identified in connection with electronic systems for future highway vehicles. These systems coutd improve the energy management and control of electric and hybrid electric light-duty vehicles. Electric drive highway vehicles will be controlled by solid state electronic devices, thereby increasing the number and complexity of interactions between system components. There will be a need tor high efficiency electronic devices and for the development of an integrated approach to vehicle electronic development. This topic is in support of the Partnership for a New Generation of Vehicles (PNGV). Grant applications are invited only in the following subtopies:

a. Hith Power Switching Controls for Hybrid Electric Vehicle Transportation Systems-Advanced semiconductor power switching devices have potential application in electric and hybrid electric passenger vehicles. Grant applications are solicited to develop silicon carbide field effect devices with siguificantly increased power density over conventional silicon devices. The proposed devices must operate in 
harsh environments (temperature extremes, tnoisture, vibration, electromaznetic interference) without requiring extreme protective measures such as climate conditioning. Grant applications should attempt to quantify: (1) the development risks inherent in scaling up the device current/power density (a scale-up factor of approximately 100 over conventional silicon devices); and (2) the cost of devices in production volumes of 20,000 to 100,000 per year.

b. Multiplexing Wiring Systems for the Control of Hybrid Electric Vehicle Powertrain and Auriliary Power Systems-Muttiplexing (interactive data communication) is forecast to be important in the car of the future. Multiplexing is a technology that allows for serial data communication instead of parallel com. municstion. If saccessfully applied, the technology will provide many system performance benefits, particularly for vehicles which are highly dependent on electronic controls. Grant appisications are sought to develop methods for utilizing multjplexing as a future data communication protocol for the hybrid vehicle electric driveline and auxiliary power (human factors power needs) control systems. Grant applications must inclute analyses to determine technology critical paths and cost effectiveness for multiplexing systems as potentially applied to hybrid vehicles.

c. Combustion Sensing for Hybrid Electric Vehicles Uning Altemative Fuels--In hybrid electric powertrain systems, sensors will be required for combustion and engine output detection and control. Hybrid vehicle engines may be smaller in power output, will likely use alternative fuels, and may perform in significantly different operational regimes then the engines in conventional vehicles. The increasing demand for simultaneous reduction in exhaust emissions and fuel consamption will farther drive the requirement for advances in electrontes, and in particular, sensors and sensing systims. Grent applications are sought to develop sensors ard sensor systems that can detect and control parameters of combustion and engine output and that een function in the operational environments of advanced hybrid vehicle engines (piston, gas turbine, diesel, or Stirling). For example, direct combustion monitoring sensors could optimize the air/fuel ratio for emissions and the energy efficiency change with the fuel's chemical composition.

\section{Bibliography}

1. "Automotive Engineering," Bociety of Automotize Engineere, April 1993, Angust 1998, April 1994 (ISSN 0098-257I).

2. Boseh, Robert, Automotive Handbook, 1998 (ISBN 156x91-372-X).

3. Heitner, K. L., "Electrie and Hybrid Yehicle System Research and Development Overview," Proceedingy of the Annual Automotive Technology Development Con. tractors Coordination Mfeeting, Dearborn, MI. November 1992 (ISBN 1-56091-368-1).

4. Honderson, J., st al, "CAR 2000: Mator Industry Research Association Report", Novembor 1998 (NTIS MIRAVCAR-2000/XAB)*

5. Yonughoniz, T. $M$, et al, "Development of Advanced High Temperature In-Cylindor Components and Tribological Systema," Proceedings of the Anntual Automative Technology Development Controctors' Coordination Meeting, Dearborn, MI, Ottober 1998 (IBBN 1-56091-539-0).

6. 1994 SAE Handbaok, Socisty of Automotive Enginasre, Vol. 24Parts and Components, (ISBN 1-5609-1461-0).

Ser Section 7.1

\section{MODULAR AND PANELIZED PASSIVE SOLAR BUILDINGS}

Moditalar and panelized buildings are manufactured at least in part in the factory, and then erected at the site. Passive solar buildings, using solar and environmental resources in combination with enercy efficiency measures, cen significantly reduce the heating, cooling, and lighting energy requirements of the buildings. Passive solat strategies in monitared residential buildings have provided 30 to $\$ 0$ percent of the heating and cooling requirements of the buildings, and reduced the heating, cooling, and lighting requirements of nonresidential buildings by 46 percent compared to conventional energy-conserving buildings of the same type. Generally, passive solar buildings cost little or no more to build than conventional ones.

Analyses have shown that advanced passive solar technologies cen potentially provide 75 to 95 percent of the heating, a significant portion of the cooling, and 80 percent of the perimeter lighting needs of a welldesigned building. To achieve this potential, buildings must be degigned with the understanding of how solar techrologies interact. with one enother ond with other 
building systems within the context of the whole building. This can be demonstrated most effectively in the design, construction, and performance monitoring of buildings. However, contributions an also be made through evaluating the potential of materials and concepts using design and analysis tools that properly account for the dynamies of passive solar buildings. Grant applications are invited only in the following subtopics:

a. Modular Townhouses for Infill HougingWidespread use of row-house construction has occurred since the settlernent of the U.S. These two and threestory units strung together along varying lengths of roadways, and derived from European housting styles, have provided efficient, affordable housing at a very "human" scale. New bousing devetopments have sought to emulate the charm and amenity of rowhouses, Modular construction, which is utilized in approximately 5 percent of new housing, has frequently been utilized for town- and row-housing. Seldom are modular urits used for town- and row-housing on urban infill sites, and seldom is passive solar design employed.

Grant applications are sought for the design and development of innovative concepts for passive solar modular townhouses appropriate for urban locations where gites range from large open areas of ten acres or more to smal] lots accommodating two or three dwelling units. Coneepts must integrate (1) passive solar heating, natural ventilation for cooling and indoor air quality, and daylighting, (2) non-toxic, recyclable materials/products, and (9) solar domestic hot vater (if merited from an economic sicandpoint). In addition, concepts must emphasize the potential for manufacturing, be realistic and repliceble in both commonityscele housing projects and small sites, address anticipated energy savings associated with passive solar design and thermal comfort, accommodate the variable orientations and surroundings of urban sites, and provide intestated passive solar destign and occupant needs for communiegtions, security, lighting, and appliances. Extra-wide modules (ranging from 16 to 24 feet in width) which incorporate the entire width of the dwelling, resulting in fewer on-site connections, are of interest as are innovative steel framing concepts that showcase non-commerejal construction suitable for urban fire districts. Grant applications should identify one or more existing modular producers, preferably those located in areas close to unan housing sites, and their involvement in Phases 1 or If of the project should be described. Grant applicationg involving improvements to existing prodacts and designs will not be considered. Likewise, applications that do hot integrate passive solar design will be declined.

\section{b. Panelized Buildinge with Masony Construo-} tion-Panelized building systems, including advancements like strutctoral insulated penels (SIPs), are becoming more widespread in commerciel and institutional building applications. Concrete tnasonry has been a staple in construction for centuries, with new systems constantly emerging. Optizel combinations of these two technologies, integrated to create passive solar non-residential buildinge, present, significant opportanities for comfortable, attractive, affordable buildings. Grant applications are solicited for the design and development of innovative concepts for passive solar commercial and institutional building construction systems that combine SIP systems and concrete masonry systems. These concepts shopid result in passive solar structures that effectively integrate: daylighting, passive solar spetce heating and ventilation preheat, nataral ventilation for cooling and indoor sir quality, and non-toxic, recyclable materials. Grant applications must address the following issues (for resolution in Phases I or II of the project): (1) anticipated solar contributions of the design to heating, cooling, and lighting needs, sevings in energy consumption, and reduction in peak electric demand, (2) the simplicity of the system and its ability to integrate electric power distribution, auxiliary HVAC systems, communications, or electronic network, (3) agse of fabrication, and (4) the interfaces between panels and masonry to minimize air infiltration and conduction losses, and to redute insect infestation and mojsture penetration. Grant applications must alsa include indications of adherence to industry standards or practices.

\section{Bibliography}

1. MeIntyre, Maureep, "The Solar Rematseance," Construction - Spedifier, V47:N8(86-96) March 1984 (ISSN 0010-6926).

2. Ravetta, A. "Daylighting Schools in North Carolina," Solar Today, V8:2(22-24) Mareh/April 1994 (1SSN 10420608).

3. Rudd, A and S. Chandre, Side-by-Bide Evaluation of a Stressed-Skin Insulated-Core Panel House and a Conventional Stud-Frame Houge, Florida Solar Bnorgy

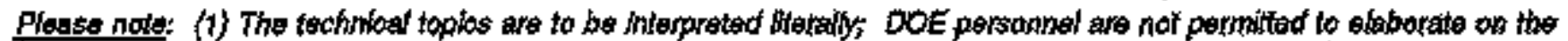

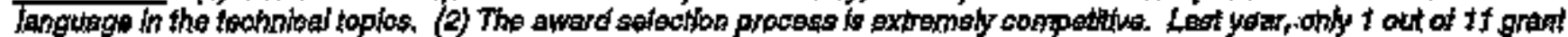

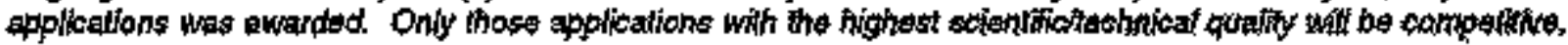


Center, FL, Report No. FSEC-CR-664-93, January 14, 1994 (NTIS Order No. DE94006452).*

4. Thayer, Burke Miller, "Esperanza del Sol: Sustainable Affordable Housing," Solar Todey, V8:N $3(20-23)$ May $f$ June 1994 (ISSN 1042-06010).

5. Winter, S., "Building with Panels," Prograsgive Architecture, V74:N11188-90), 1983 (ISSN 0083-0752).

6. Jenior, M. M., "Solar Buildings for a Sugtainate America," Solar Today, V8:N2(12 15), March/April 1994 (ISSN 1042-0630).

* See Sertion 7.1

\section{TECHNICAL IMPROVEMENTS FOR ADVANCING PHOTOVOLTAIC APPLICATIONS}

The technical feasibility of photovoltaics (PV) has been accepted for some trime, and niche markets exist for terrestrial applications. However, significant technical problems must be solved before photovaltaic costs come down and markets grow to multibillion dollar annual sizes. Grant applications are invited only in the following subtopics:

a. Environmentally Responsible Methods of Removing and Recycling Thin Film Photovoltaic semiconductors-Thin film PV modules often contain materials that could be recycled in order to reduce their potential environmental impact and/or regain their value for future use. Grant applications are sought for new capabilities to remove thin film materials for example, cadmiju, selenium, gallium, indjum, and tellurium in CuInSe $e_{2}$ and CdTe devices) from glass or similar low-cost substrates in order to facilitate recycling. Criteria for success are: cost of the procedure, completeness of the removal, minimization of unwanted waste streams resulting from the procedure, and usability of removed material for recycling.

b. Low-Cost, Module-Ready Arrays/Systems for Large Markets-Grant applications are solicited for the development of low cost, highly integrated PV arrays that could meet competitive cost goals if they were produced and installed in volume. Design criteria must address: (1) the integration of modules into arrays and the deployment of the arrays in the field; (2) flexibility for integration with various pre-packaged module assemblies that could be shipped easily to the system site; (3) reduced materials and uanufacturing costs, ease of transport and installation (including module assembly), and general usefulness for large photovoltaic markets; and (4) balance-of-system cost reductions (excluding power conditioning) in order to make systems cost competitive. Proposers should be prepared to build and instal] prototype arrays in Phese II.

c. Large Area Nonpulsed Solar Bimulators-The use of simulators to measure the efficiency of PV cells and modules is critical for determining performance, both for research and development purposes and in order to establish projections for outdoor energy production, Most of today's commercial simulators use light pulses to activate photovoltaic cells/modules. However, such pulsed simulators can cause unexpected measurement artifacts in some of today's advanced PV technologies (especially thin films and multifunctions). Grant applications are solieited for the design and prototype assembly of a new generation of non-pulsed PV simulators for large area modules ( $1 \mathrm{~m}^{2}$ and larger) suitable for use with advanced photovoltoics. These simulators must retain the same quality as previous simulators (e.g., in terms of area untormity, repeatability, and temperature control). Cost and ease of use of the proposed simutators should also be addressed.

d. Increased Photovoltaic Wafer Productivity by Cutting Thinner Wafers with Legs Kerf LossSolar cells fabricated using wafers cut from ingots of crystalline silicon dominate the current market for PV madules. A significant way to reduce costs is to cut more wafers from each ingot. This can be accomplished by reducing the thickness of the wafers and by reducing kerf loss in the sawing operation. Until recently, conventional inner diameter blade saws have been used to cut these wafers, but wire saws are now recognized as a superior alternative. Grant applications are sought for improved wire-sew technology, or entirely new equipment and techniques, that will increase the yield of wafers less than $\mathbf{8 0 0}$ micrometers thick.

\section{Bibliography}

1. "Block V Solar Cell Module: Design and Teat Spećfiestion for Intermediate-Load Applications," Jet Proppleion Laboratory, Pasadena, CA, 38 Pp, February 20, 1981 (NTIS Order No. DOE/CS/81087-T1)."

2. DeBlatio, R., et al, "Interim Qualifitation Testa and Procedures for Terrestrial Photovoltaic Thín-Film Flat- 
Flate Modules," pp. 796.801, January 1990, Report No.sERVTR-218-3624 (NTIS Order No. DE90000854)*

3. Five Year Regearch Plan 1987-1991, Photovoltaicet USA's Bnergy Opportunity," U.S. Department of Enorgy May 1987, Report No. DOE/CH10083-7, pp. $27-31$ (NTIS Order Na. DE97009110)."

4. Moekowitz, P. D., et al, "Health Safaty and Gnviron. mental Iseves Relating to Cadmium Usage in Photovoltaic Energy Gyetems," 29 pp., January 1990 (NTIS Order No. DE90000810XAB),

5. Moekowitz, P. D., et al, "Rocycling of Cadmins and Solenium from Phatovoltatc Modules and Menuficturing Waates, A Workshop Report," Brookhaven National Laboratory Report No. BNL.4778?, CONF-9202208, 1992 (NTJS Ordor No. DE93002115/XAB)**

6. "Phatoveltaica Pragram Plan FY 1991-FY 1995," U.S. Depertment of Energy, p. 44, Oetober 1991, Regart No. DOECH10098/92 (NTIS Ordor No. DE91002139).*

7. "Recommended Criteria for Terreetrial Photovoitafcs Power Systems (R1991)," 12 pp, 1986, EEEE Industry Standers (USTD), (IEEE Catalog No. 928-1986).**

9. Zwotbel, K, Harneseing Salar Power: The Photovoltaics Challenge, New Yorks Flenum Prees, 1990 (ISBN No. 0706-48564-0).

a. Zure(bel K, and A.M. Bamett, Polyerrgtalline Thin Filn Phatovaltaic: In Funale and Flectriclty from Renewable Enerry pp. 487-481, 1998 (18BN 1-56968-138-4).

Ege Sotion 7.1

W* Available from IEEE Service Center, 445 Hoes Lans, Piocatawray, NJ 08B64 (Telephone 800.679.4988) 